UDK 902

ISSN 1330-0644

VOL 36/2019.

ZAGREB, 2019.

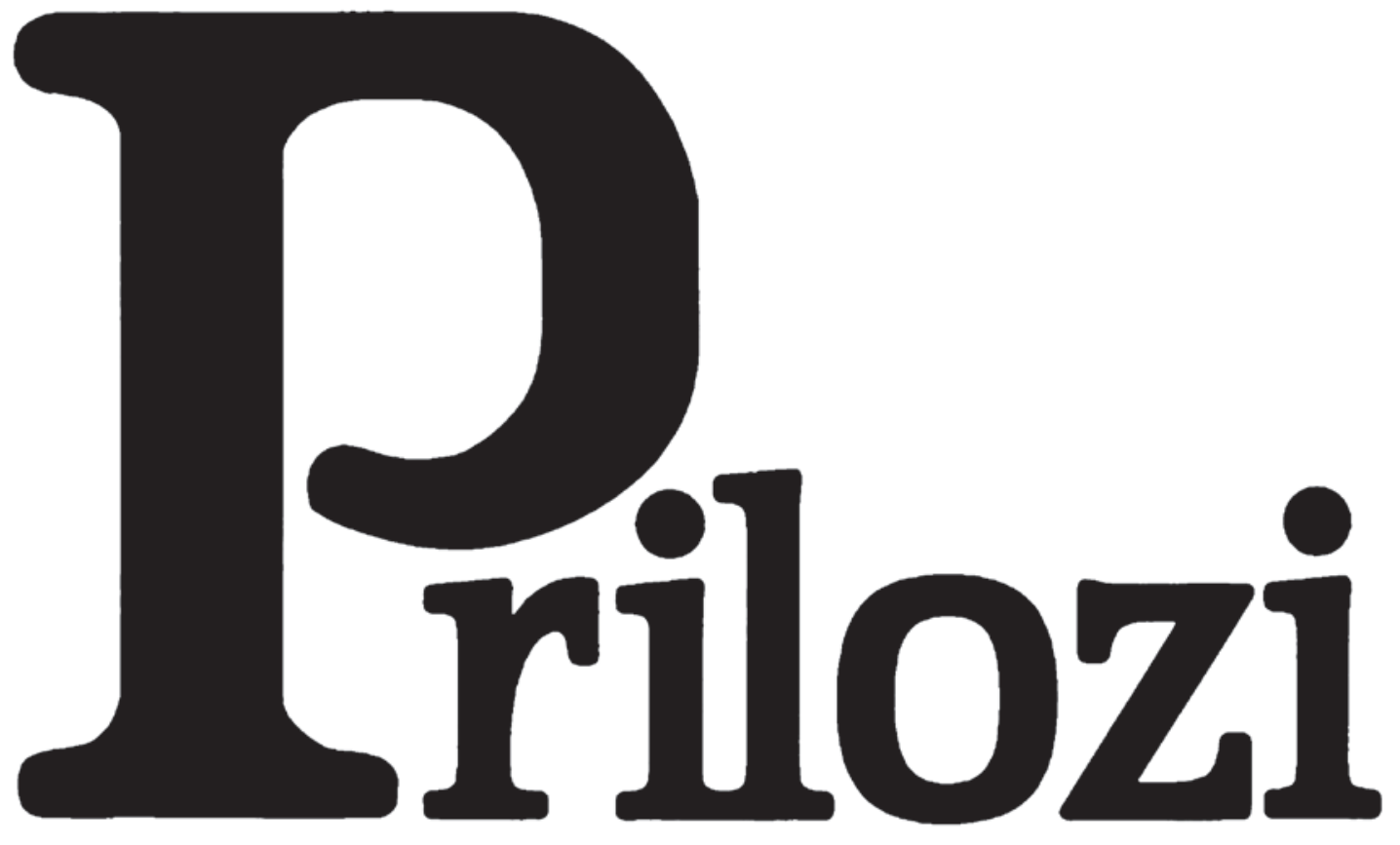

Instituta za arheologiju u Zagrebu 
Pril. Inst. arheol. Zagrebu, 36/2019

Str./Pages 1-196, Zagreb, 2019.
Izdavač/Publisher

INSTITUT ZA ARHEOLOGIJU

INSTITUTE OF ARCHAEOLOGY

Adresa uredništva/Address of the editor's office

Institut za arheologiju/Institute of archaeology

HR-10000 Zagreb, Ulica Ljudevita Gaja 32

Hrvatska/Croatia

Telefon/Phone ++385/(0)1 6150250

Fax $++385(0) 16055806$

e-mail: urednistvo.prilozi@iarh.hr

http://www.iarh.hr

Glavni i odgovorni urednik/Editor in chief

Marko DIZDAR

Uredništvo/Editorial board

Marko DIZDAR, Snježana KARAVANIĆ, Viktória KISS (Budapest, HUN) (prapovijest/Prehistory), Goranka LIPOVAC VRKLJAN (antika/Antiquities), Tajana SEKELJ IVANČAN, Katarina Katja PREDOVNIK (Ljubljana, SLO), Natascha MEHLER (Wien, AUT), Juraj BELAJ, Tatjana TKALČEC (srednji vijek i novi vijek/Middle Ages and Modern era), Predrag NOVAKOVIĆ (Ljubljana, SLO) (metodologija/Methodology)

Izdavački savjet/Editorial advisory board

Dunja GLOGOVIĆ (Zagreb), Ivor KARAVANIĆ (Zagreb), Laszlo KÓVACS (Budapest, HUN),

Kornelija MINICHREITER (Zagreb), Mladen RADIĆ (Osijek), Aleksandar RUTTKAY (Nitra, SK), Ivančica SCHRUNK (Minneapolis, USA), Željko TOMIČIĆ (Zagreb), Ante UGLEŠIĆ (Zadar)

Prijevod na engleski/English translation

Ivan ARBANAS, Marko BANDA, Domagoj BUŽANIĆ, Mario CARIĆ, Marko MARAS, Andreja MAVER, Goran TOMAC, Mirna VUKOV

Lektura/Language editor

Ivana MAJER (hrvatski jezik/Croatian)

Marko MARAS (engleski jezik/English)

Korektura/Proofreads

Katarina BOTIĆ

Marko DIZDAR

Grafičko oblikovanje/Graphic design

Roko BOLANČA

Računalni slog/Layout

Hrvoje JAMBREK

Tisak/Printed by

Tiskara Zelina d.d., Sv. I. Zelina

Naklada/Issued

400 primjeraka/400 copies

Prilozi Instituta za arheologiju u Zagrebu uključeni su u sljedeće indekse/ Prilozi Instituta za arheologiju u Zagrebu are included in following indices:

DYABOLA - Sachkatalog der Bibliothek - Römisch-Germanische Kommission des Deutschen Archaeologischen Instituts, Frankfurt a. Main

Clarivate Analytics services - Emerging Sources Citation Index

CNRS/INIST - Centre National de la Recherche Scientifi que/L'Institut de I'Information Scientifi que et Technique, Vandoeuvre-lès-Nancy

EBSCO - Information servises, Ipswich

ERIH - European Reference Index for the Humanities, European Science Fundation, Strasbourg SciVerse Scopus - Elsevier, Amsterdam 
Sadržaj

\section{Izvorni znanstveni radovi}

MARKO BANDA

IVOR KARAVANIĆ

Mustjerska industrija špilje Veternice

41

\author{
RAJNA ŠOŠIĆ KLINDŽIĆ \\ HRVOJE KALAFATIĆ \\ BARTUL ŠILJEG \\ TOMISLAV HRŠAK
}

Krugovi i keramika kroz stoljeća: značajke naselja

sopotske kulture

\section{DARIA LOŽNJAK DIZDAR}

Status žena u podunavskim zajednicama u starijem željeznom dobu -

Primjer groba 1 iz Sotina

121

MIRJANA SANADER

MIRNA VUKOV

DOMAGOJ BUŽANIĆ

Pax Romana između Burna i Tilurija.

Krajolik sukoba?

135 MITJA GUŠTIN

The belt-buckle with Bacchus from "Romuliana"

143 MAJA BAUSOVAC

Kasnorimski lonci za pohranu s T-oblikom ruba iz Rifnika kod Celja

\section{Contents}

\section{Original scientific papers}

\author{
MARKO BANDA \\ IVOR KARAVANIĆ \\ The Mousterian industry of Veternica Cave
}

\author{
RAJNA ŠOŠIĆ KLINDŽIĆ \\ HRVOJE KALAFATIĆ \\ BARTUL ŠILJEG \\ TOMISLAV HRŠAK \\ Circles and ceramics through the centuries: \\ Characteristics of Neolithic Sopot culture settlements
}

\section{DARIA LOŽNJAK DIZDAR}

Status of women in the Danube Basin communities in the Early Iron Age-

Example of grave 1 from Sotin

\section{MIRJANA SANADER \\ MIRNA VUKOV \\ DOMAGOJ BUŽANIĆ}

Pax Romana between Burnum and Tilurium.

Landscape of conflicts?

\section{MITJA GUŠTIN}

Pojasna kopča s Bakhom iz „Romuliane”

MAJA BAUSOVAC

Late Roman storage jars with a T-shaped rim from Rifnik near Celje, Slovenia 
BRINA ZAGORC

DARIA LOŽNJAK DIZDAR

ANITA RAPAN PAPEŠA

ANDREA RIMPF

MISLAV ČAVKA

IVOR JANKOVIĆ

MARIO NOVAK

Bioarheologija kasnoavarske populacije iz nalazišta

Šarengrad - Klopare: preliminarni rezultati

\section{Prikazi}

KREŠIMIR MIJIĆ

Tomislav Fabijanić, Miroslav Glavičić, Mirko Rašić, Kulturno povijesna baština općine Ljubuški: Zbornik radova

KREŠIMIR MIJIĆ

Irena Radić Rossi - Giulia Boetto (ur.), Pakoštane - Veli Školj: Kasnoantički brodolom u geološkogeografskom i kulturno-povijesnom kontekstu
MARIO CARIĆ

BRINA ZAGORC

DARIA LOŽNJAK DIZDAR

ANITA RAPAN PAPEŠA

ANDREA RIMPF

MISLAV ČAVKA

IVOR JANKOVIĆ

MARIO NOVAK

Bioarchaeology of the Late Avar population from Šarengrad - Klopare: preliminary results

\section{Book reviews}

\section{KREŠIMIR MIJIĆ}

Tomislav Fabijanić, Miroslav Glavičić, Mirko Rašić, The Culture-historical Heritage of the municipality of Ljubuški: The Collection of Papers

\section{KREŠIMIR MIJIĆ}

Irena Radić Rossi - Giulia Boetto (eds.), Pakoštane - Veli Školj: The Late Roman Shipwreck in Its Geological-geographic and Cultural-historical Context 


\title{
Mustjerska industrija špilje Veternice
}

\section{The Mousterian industry of Veternica Cave}

\author{
Izvorni znanstveni rad \\ Prapovijesna arheologija \\ Original scientific paper \\ Prehistoric archaeology \\ UDK/UDC 903.1(497.5 Zagreb)"632" \\ Primljeno/Received: 19. 01. 2019. \\ Prihvaćeno/Accepted: 29. 07. 2019.
}

\author{
MARKO BANDA \\ Sadska 5 \\ HR-51000 Rijeka \\ markobanda0@gmail.com \\ IVOR KARAVANIĆ \\ Odsjek za arheologiju, Filozofski fakultet Sveučilišta u \\ Zagrebu \\ Ivana Lučića 3 \\ HR-10000 Zagreb \\ Department of Anthropology, University of Wyoming \\ Laramie, WY-82071 \\ USA \\ ikaravan@ffzg.hr
}

\begin{abstract}
Špilja Veternica nalazište je srednjega paleolitika na jugozapadnome dijelu planine Medvednice u Hrvatskoj. Nalazište je od 1951. do 1955. $i$ 1971. godine istraživano i u njemu su prikupljene stotine kamenih izrađevina mustjerske kulture. Ovaj rad donosi litičku analizu tih izrađevina $i$, usprkos pomiješanim nalazima iz više slojeva, važne podatke o tehnologiji, tipologiji i korištenju sirovina. Na temelju dobivenih rezultata $i$ usporedbe s drugim nalazištima u susjednim prostorima, srednjopaleolitička industrija Veternica smještena je u kronološki i kulturni okvir.
\end{abstract}

Ključne riječi: srednji paleolitik, mustjerska kultura, tehnologija, tipologija, sirovine, Veternica

Veternica Cave is a Middle Paleolithic site located on the southwestern part of Medvednica Mountain, Croatia. From 1951 to 1955 and in 1971 the site was excavated and hundreds of stone artefacts of the Mousterian culture were collected. This paper presents a lithic analysis of these artefacts and, in spite of mixed finds from multiple layers, gives important data on technology, typology and raw material use. Based on the results and the comparison with other sites in the neighbouring regions, the Middle Paleolithic industry of Veternica is placed in a chronological and cultural framework.

Key words: Middle Paleolithic, Mousterian culture, technology, typology, raw materials, Veternica

\section{UVOD}

Špilja Veternica jedno je od nalazišta srednjega paleolitika u sjeverozapadnoj Hrvatskoj te pripada važnim nalazištima u tome prostoru među koje se ubrajaju Hušnjakov brijeg u Krapini, Vindija i Velika pećina. U istraživanjima Veternice od 1951. do 1955. te 1971. godine pronađeno je nekoliko stotina lomljenih kamenih izrađevina koje predstavljaju kamena oruđa te ostatke od njihove proizvodnje. Budući da se mustjerska industrija u Europi isključivo povezuje s neandertalcima, s istim ljudima (Homo sapiens neanderthalensis) valja povezati i litičke nalaze iz Veternice. Usprkos važnosti nalazišta za proučavanje srednjega paleolitika u srednjoj i jugoistočnoj Europi, a napose za srednji paleolitik sjeverozapadne Hrvatske, veći dio litičkoga skupa Veternice nije dosad bio sustavno analiziran i objavljen. Litičkom analizom, temeljenom na različitim pristupima, provedena je re-

\section{INTRODUCTION}

Veternica Cave is one of several Middle Paleolithic sites in northwestern Croatia which include Krapina, Vindija, and Velika pećina. During the research of Veternica from 1951 to 1955 and in 1971 a few hundred knapped stone artefacts were found, representing stone tools and the remains of their manufacture. Since the Mousterian industry in Europe is exclusively linked to the Neanderthals, the lithic finds from Veternica should be attributed to the same human subspecies (Homo sapiens neanderthalensis). Despite the significance of the site for the study of the Middle Paleolithic in Central and Southeast Europe, and especially for the Middle Paleolithic in northwest Croatia, the majority of the lithic assemblage of Veternica has not been systematically studied and published. A revision has been conducted using 
vizija materijala. Nazivlje na hrvatskome korišteno je prema Pojmovniku kamenog doba (Karavanić et al. 2015). Analiza skupa nalaza bila je vezana za dva cilja, od kojih je primarni bio dobivanje što veće količine podataka zbog vjernije rekonstrukcije proizvodnje kamenih oruđa. Na taj se način kroz prizmu tehnologije kamenih izrađevina nastojalo baciti više svjetla na način života neandertalskih zajednica koje su obitavale u špilji. Međutim, glavni cilj analize bio je na osnovi dobivenih podataka litičku industriju Veternice kronološki i kulturalno povezati s drugim nalazištima u sjeverozapadnoj Hrvatskoj i susjednim regijama. U tome smislu, revizija kamenih artefakata poslužila je i kao nadopuna slici srednjega paleolitika, odnosno mustjerske industrije na navedenome prostoru. different approaches to the lithic analysis. The Croatian terminology follows the dictionary Pojmovnik kamenog doba [Stone Age Glossary] (Karavanić et al. 2015). The analysis of the assemblage had two goals, of which the primary was the acquirement of data for a faithful reconstruction of stone tool manufacture. It was endeavoured through the lens of technology to shed more light on the way of life of the Neanderthal groups which occupied the cave. However, the main goal of the analysis was to chronologically and culturally relate the lithic industry of Veternica to other sites in northwest Croatia and neighbouring regions on the basis of acquired data. In that sense, the revision of stone artefacts supplemented the picture of Middle Paleolithic and Mousterian industry in the mentioned area.

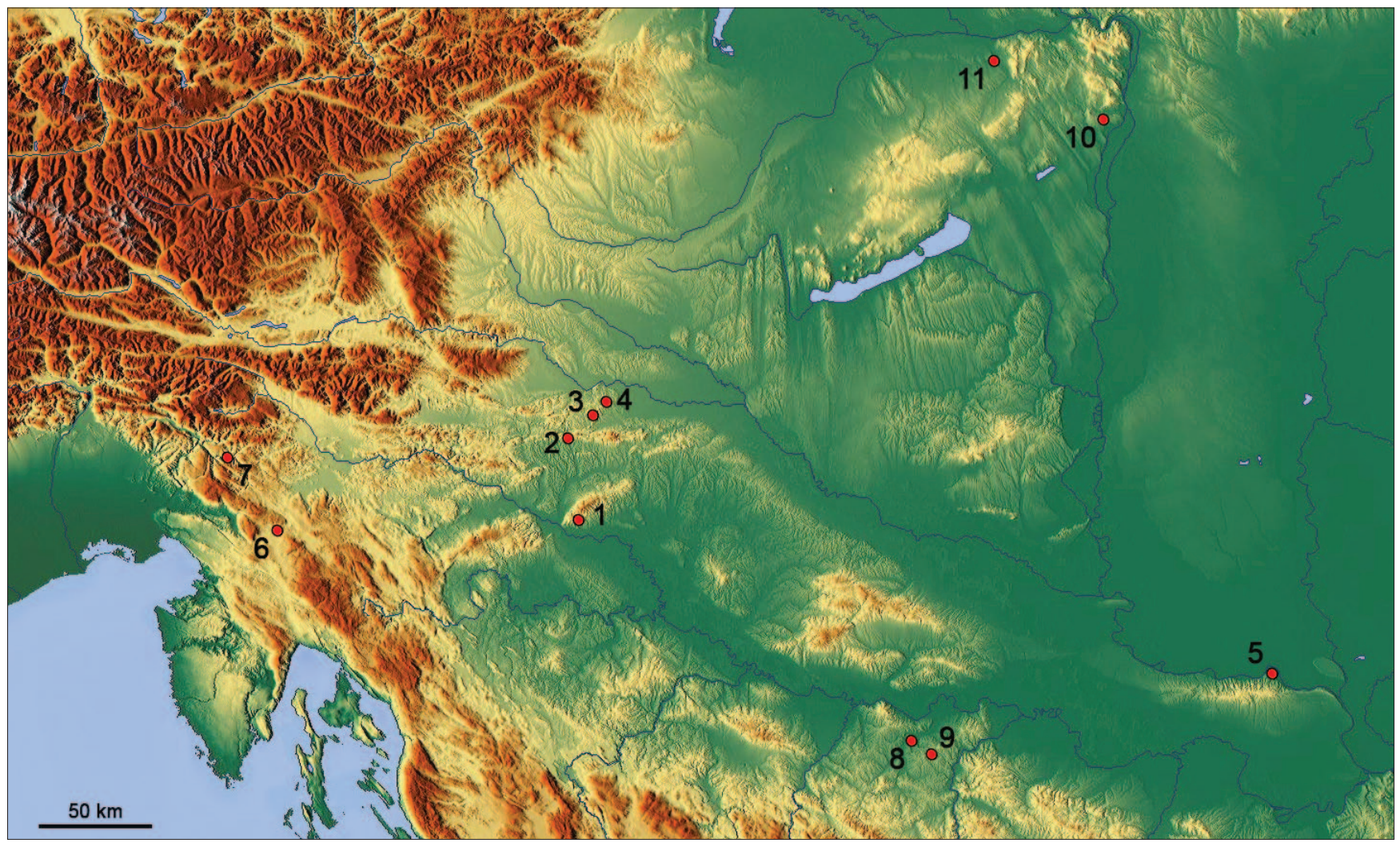

Karta 1 Geografski položaj špilje Veternice i najvažnijih nalazišta koja se spominju u tekstu: 1 Veternica; 2 Krapina; 3 Velika pećina; 4 Vindija; 5 Petrovaradinska tvrđava; 6 Betalov spodmol; 7 Divje babe I; 8 Zobište; 9 Visoko Brdo; 10 Érd; 11. Tata (izradio: M. Banda, 2019.) Map 1 Geographic location of Veternica Cave and the most important sites mentioned in the text: 1 Veternica; 2 Krapina; 3 Velika pećina; 4 Vindija; 5 Petrovaradinska tvrđava; 6 Betalov spodmol; 7 Divje babe l; 8 Zobište; 9 Visoko Brdo; 10 Érd; 11 Tata (made by: M. Banda, 2019)

\section{GEOGRAFSKI I GEOLOŠKI KONTEKST}

Špilja Veternica nalazi se na jugozapadnome dijelu planine Medvednice (karta 1), u usjeku između dva brdovita vrha, Glavice i Jaruge, na položaju koji je poznat i pod imenom Pećinsko rebro (Malez 1965: 176). Ulaz špilje nalazi se na 306 $\mathrm{m}$ nadmorske visine, a okrenut je prema jugu, odnosno jugoistoku te veći dio dana izložen danjem svjetlu (Malez 1965: 178; Miracle, Brajković 1992: 2). Današnja širina ulaza iznosi oko $8 \mathrm{~m}$, a visina više od $4 \mathrm{~m}$, dok je prije istraživanja ulaz bio znatno manjih dimenzija (Malez 1965: 178). Sama špilja je razgranata, sastoji se od glavnoga podzemnog hodnika

\section{GEOGRAPHICAL AND GEOLOGICAL CONTEXT}

Veternica Cave is located on the southwestern part of Medvednica Mountain (Map 1), in a ravine between two hilltops, Glavica and Jaruga, on a site also known as Pećinsko rebro (Malez 1965: 176). The cave entrance stands at 306 $\mathrm{m}$ a.s.l., faces south-southwest, and is exposed to daylight most of the day (Malez 1965: 178; Miracle, Brajković 1992: 2). The entrance currently measures about $8 \mathrm{~m}$ in width and more than $4 \mathrm{~m}$ in height, but it was considerably smaller before the excavations (Malez 1965: 178). The cave itself is 
od kojega se mjestimice odvajaju manji kanali (Božičević 1995: 48), a ukupna horiozntalna duljina cijeloga pećinskog sustava iznosi 7128 metara (http://speleologija.hr/popis, pristupljeno 21. 01. 2019). Formacija je nastala djelovanjem voda na granici transgresije između trijaskih i miocenskih vapnenaca, ponajprije djelovanjem voda ponornica koje se slijevaju u krško polje Ponikve, sjeveroistočno od ulaza špilje (Malez 1965: 182). Spomenute vode su tijekom pleistocena probile kanal i otvor kojim je voda otjecala niz planinske padine, a kasnijim probijanjem sporednih odvodnih kanala dublje u špilji, presušen je ulazni dio te posljedično omogućena sedimentacija (Malez 1965: 184). lako je Veternica zanimljiv geomorfološki spomenik, zaštićen od 1979., za interes arheološke znanosti važan je samo ulazni dio špilje (sl. 1). Taj dio sastoji se od ulazne dvorane dužine 15 i širine više branched, consisting of a main subterranean passage with smaller interspersed passages separating from it (Božičević 1995: 48). The total horizontal length of the entire cave system is 7128 metres (http://speleologija.hr/popis, accessed 21/01/2019). The cave was formed by water erosion on a transgression boundary between Triassic and Miocene limestone formations, primarily by subterranean waters which flow into Ponikve, a karst field northeast of the cave entrance (Malez 1965: 182). During the Pleistocene, the waters first carved out a canal and then an entrance through which the water flowed down the mountain slopes. In later formation phases, drainage canals were penetrated deeper inside the cave, drying up the entrance area and consequently enabling sedimentation (Malez 1965: 184). Although Veternica is an interesting geomorphological monument, protected since 1979, only the entrance area is of interest to archaeological science (Fig. 1). This area consist of an en-

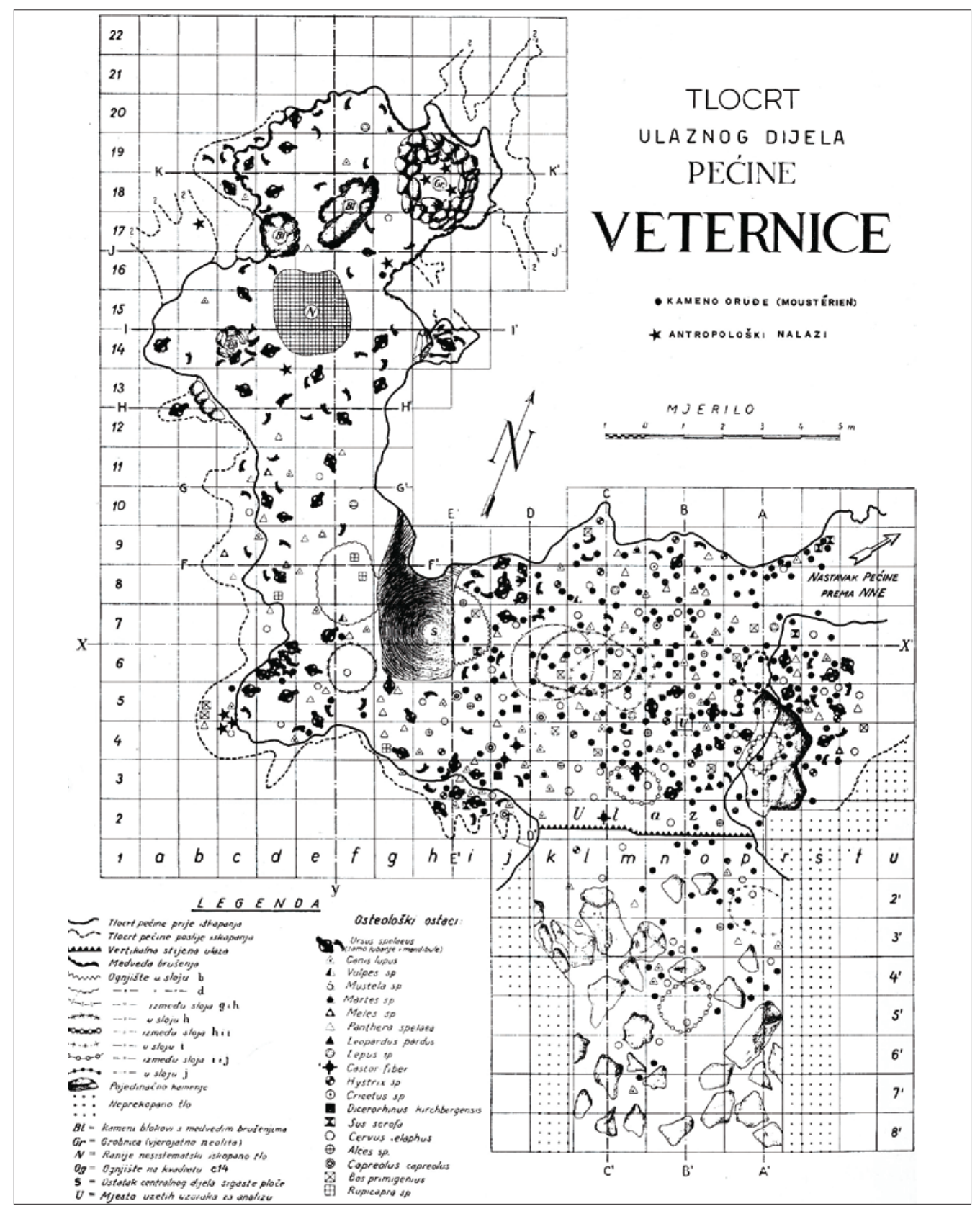

SI. 1 Tlocrt ulaznoga dijela špilje Veternice (prema: Malez 1981: sl. 2; doradio: M. Banda, 2019.)

Fig. 1 Ground plan of the entrance area of Veternica Cave (after:Malez 1981: Fig. 2; modified by: M. Banda, 2019) 
od 8 m, čija je orijentacija jugozapad-sjeveroistok. Najveća visina ulazne dvorane izmjerena je $u$ jednome udubljenju $\mathrm{u}$ stropu te iznosi više od $8 \mathrm{~m}$, dok je prosječna visina oko 5 $\mathrm{m}$. Od ulazne dvorane prema sjeverozapadu odvaja se lijevi hodnik čija dužina iznosi $14 \mathrm{~m}$, širina varira od 3 do $7 \mathrm{~m}$, a visina od 4,5 do $6 \mathrm{~m}$ (Malez 1965: 178-179).

\section{POVIJEST ISTRAŽIVANJA}

Špilja se prvi puta u stručnoj literaturi spominje na prijelazu iz 19. u 20. stoljeće. Tada ju je D. Gorjanović-Kramberger (1899: 164) samo opisao kao mali otvor špilje na jugozapadnome dijelu Zagrebačke gore (Medvednice) iz koje struji hladan zrak. D. Hirc (1903: 8; 1904: 154, 698) u svojim radovima na početku 20. stoljeća prvi puta spominje ime Veternica i tumači etimologiju naziva upravo kroz fenomen strujanja zraka. Prva stručna istraživanja provedena su 1934. godine kada je J. Poljak (1934: 138) posjetio i istražio špilju do otprilike 1488 metara. U literaturi se navodi podatak kako je 1940. godine provedeno nesustavno iskopavanje (Božičević 1961: 77), ali nisu dostupni nikakvi podaci glede pronađenih nalaza ili stratigrafije. Nakon Drugoga svjetskog rata proširuje se interes za proučavanje špilje, u prvome redu speleološko, u čemu je glavnu ulogu mahom odigrala Speleološka sekcija Planinarskoga društva Željezničar. Prilikom proširivanja ulaza 1950. godine u špilji su pronađeni arheološki ostaci te su se članovi speleološke sekcije obratili arheolozima i antropolozima za pomoć (Božičević 1961: 79-80). Godine 1951. započinju probna istraživanja u špilji pod vodstvom Slavka Marjanca, tajnika Speleološke sekcije PD Željezničara, a nastavljaju se i 1952. godine (Božičević 1961: 80). Već sljedeće sezone, 1953. godine, vodstvo nad istraživanjima preuzima Mirko Malez, tada asistent u Komisiji za naučno istraživanje krša Jugoslavenske akademije znanosti i umjetnosti (Božić 2003: 91; Paunović 1992: 12). Malez istražuje veći dio ulazne dvorane, lijevoga hodnika i predšpiljskoga prostora. Istraživačke kampanje trajale su do 1955. godine, a na kraju istraživanja ostavljena su dva profila, jedan u desnome (sjeveroistočnome), a drugi u središnjem dijelu ulazne dvorane (Malez 1974a: 216; 1974b: 264). Upitno je jesu li istraživanja Mirka Maleza završila 1955. jer u dvije objave Malez (1958: 5; 1958/1959: 187) navodi kako su istraživanja provedena i u 1956. godini. Međutim, u kasnijim radovima (Malez 1965: 190; 1967: 257; 1981: 65) redovito se navodi da su istraživanja trajala do 1955. godine. U svakome slučaju, istraživanja Veternice nisu tada u potpunosti završena, već je Malez 1971. godine ponovno posjetio špilju i istražio preostale profile, u prvome redu kako bi prikupio uzorke za radiokarbonsko datiranje (Malez 1972: 216; 1974a: 14). U tu svrhu očišćena su dva navedena zaštitna profila na kojima su bili sačuvani holocenski i pleistocenski sedimenti (Malez 1972: 216), pri čemu su, osim uzoraka, prikupljeni i nalazi faune, kamenih izrađevina i koštanih obrađivača (Malez 1972: 216). U konačnici su sveukupna istraživanja Mirka Maleza i njegovih prethodnika obuhvatila površinu od oko 207 m² (Miracle, Brajković 1992: 2). Godine 2015. pokrenuta su zaštitna istraživanja u Veternici na mjestu na kojem je trance chamber $15 \mathrm{~m}$ long and more than $8 \mathrm{~m}$ wide, oriented southwest-northeast. The greatest height of the entrance chamber, $8 \mathrm{~m}$, was measured in a recess in the ceiling, while the average height is about $5 \mathrm{~m}$. A distinct left hall separates from the entrance chamber towards the northwest. It is $14 \mathrm{~m}$ long, 3 to $7 \mathrm{~m}$ wide, and 4.5 to $6 \mathrm{~m}$ tall (Malez 1965: 178-179).

\section{RESEARCH HISTORY}

The first mention of the cave in literature dates from the turn of the $19^{\text {th }}$ and $20^{\text {th }}$ centuries, when D. GorjanovićKramberger (1899: 164) described it as a small cave entrance on the southwestern part of Zagrebačka gora (Medvednica Mountain) with cold air flowing from it. In his works at the beginning of the $20^{\text {th }}$ century, D. Hirc (1903: 8; 1904: 154, 698) first mentioned the name Veternica and explained the etymology of the name with the phenomenon of air flow. Research was first conducted in 1934, when J. Poljak (1934: 138) visited the cave and explored it to about 1488 metres. Literature mentions an unsystematic excavation in 1940 (Božičević 1961: 77), but there are no available data regarding its finds or stratigraphy. After the Second World War there was a growing interest in the exploration of the cave, primarily speleological, where the main role was played by the Speleological Department of the Mountaineering Society Željezničar. When the entrance was expanded in 1950, archaeological remains were found inside the cave, and the members of the Speleological Department turned to archaeologists and anthropologists for assistance (Božičević 1961: 79-80). In 1951 test excavations began in the cave under the supervision of Slavko Marjanac, the secretary of the Speleological Department of MS Željezničar, and continued in 1952 (Božičević 1961: 80). In the next season (1953), the supervision of the excavation was taken over by Mirko Malez, assistant in the Committee for Karst Research of the Yugoslav Academy of Sciences and Arts (today Croatian Academy of Sciences and Arts) (Božić 2003: 91; Paunović 1992: 12). Malez excavated most of the entrance chamber, the left hall, and the space in front of the cave. Research seasons went on until 1955; at the end of the excavation two profiles had been left behind in the entrance chamber, one in the right (northeastern) part, the other in the central part (Malez 1974a: 216; 1974b: 264). It is unclear if the excavations of Mirko Malez ended in 1955, because Malez mentions in two publications (1958: 5; 1958/1959: 187) that excavations were conducted in 1956 too. However, all later publications (Malez 1965: 190; 1967: 257; 1981: 65) mention that the excavations lasted until 1955. In any case, the excavations in Veternica did not completely cease, and Malez visited the cave again in 1971 and excavated the remaining profiles, primarily in order to collect samples for radiocarbon dating (Malez 1972: 216; 1974a: 14). For that purpose, the two mentioned profiles, with preserved sediments dating from the Holocene and Pleistocene, were cleaned (Malez 1971: 216) and the faunal remains, stone artefacts and bone retouchers were collected besides the samples for dating (Malez 1972: 216). Ultimately, the excavations of Mirko Malez and his predecessors encompassed a surface of about 
2002. godine pronađena lubanja čovjeka naše podvrste Homo sapiens sapiensa (Vukosavljević et al. 2015), odnosno $\mathrm{u}$ istočnome dijelu ulazne dvorane. Istraživanja su zahvatila holocenske i pleistocenske slojeve, pronađeni su arheološki ostaci iz holocenskih razdoblja, pleistocenski paleontološki ostaci te ljudski ostaci iz razdoblja antike (Vukosavljević et al. 2015; Vukosavljević, Raguž 2016), ali u pleistocenskim slojevima nisu pronađeni artefakti (Vukosavljević, usmeno priopćenje).

\section{STRATIGRAFIJA I KRONOLOGIJA}

U Veternici je u najcjelovitijim stratigrafskim sekvencama prepoznato 11 slojeva (Miracle, Brajković 1992: 2) (sl. 2). Prvotno su slojevi bili zasebno označeni brojevima u pojedinim dijelovima špilje (Malez 1955; 1956a; 1957), ali su nakon završetka istraživanja i povezivanja označeni slovima od A do K (Malez 1958/1959; 1964; 1965; 1972; 1974a; 1979; 1981). Ukupna debljina sedimenata mjestimice je varirala od 4 do 7 m iznad matične stijene (Malez 1958/1959: 171), ali se u predšpiljskome prostoru nije dosegla matična stijena, već sterilni sloj na dubini od 8 m (Miracle, Brajković 1992: 2). Debljina sedimenata u prvome je redu ovisila od morfologiji matične stijene, koja je u lijevome hodniku bila izdignuta $u$ odnosu na ulaznu dvoranu, pa su na tome mjestu sedimenti u prosjeku bili tanji, a nedostajali su i najdublji slojevi zabilježeni u ulaznoj dvorani (Malez 1965: 195).

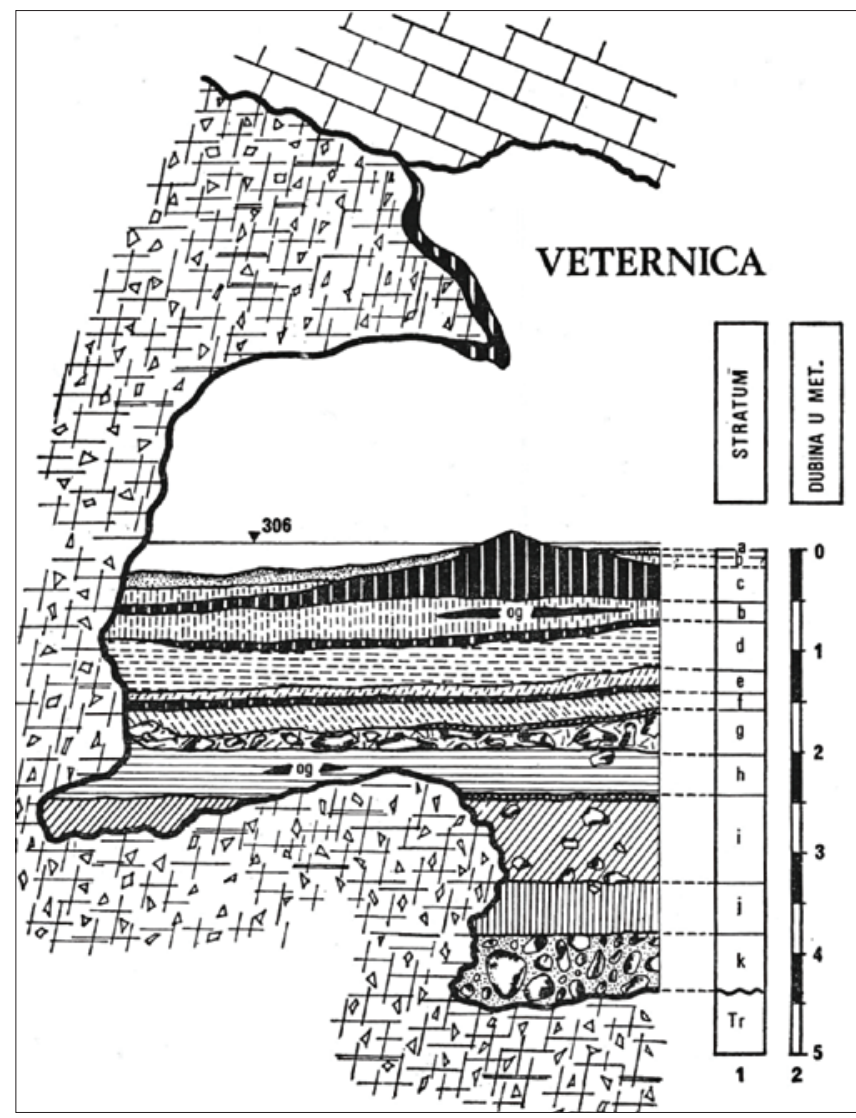

SI. 2 Stratigrafski profil špilje Veternice (prema: Malez 1981: sl. 2; doradio: M. Banda, 2019.)

Fig. 2 Stratigraphic profile of Veternica Cave (after:Malez 1981: Fig. 2; modified by: M. Banda, 2019)
207 m² (Miracle, Brajković 1992: 2). In 2015 rescue excavations started on a position in Veternica where a human skull belonging to our subspecies, - Homo sapiens sapiens, had been found in 2002 (Vukosavljević et al. 2015), more precisely in the eastern part of the entrance chamber. The excavations encompassed the Holocene and Pleistocene layers and found Holocene archaeological remains, Pleistocene paleontological remains, and human remains from the Roman period (Vukosavljević et al. 2015; Vukosavljević, Raguž 2016). However, no artefacts were found in the Pleistocene layers (Vukosavljević, personal communication).

\section{STRATIGRAPHY AND CHRONOLOGY}

Eleven layers were recognized in the most complete stratigraphic sequences of Veternica (Miracle, Brajković 1992: 2) (Fig. 2). At first the layers were labelled with numbers in separate parts of the cave (Malez 1955; 1956a; 1957), but after the excavation was finished, the layers were linked and labelled with letters from A to K (Malez 1958/1959; 1964; 1965; 1972; 1974a; 1979; 1981). The total thickness of the sediments varied from 4 to $7 \mathrm{~m}$ above bedrock (Malez 1958/1959: 171). However, the excavations in front of the cave did not reach the bedrock, but a sterile layer at the depth of about $8 \mathrm{~m}$ (Miracle, Brajković 1992: 2). Sediment thickness was contingent first and foremost upon the morphology of the bedrock, which was raised in the left hall in relation to the entrance chamber, so the sediments in that area were thinner on average, and the deepest layers of the entrance chamber were absent (Malez 1965: 195).

Layers A and B contained archaeological finds from different periods of the Holocene (Malez 1965: 197, 199). A flowstone separating Holocene and Pleistocene layers in a part of the cave was labelled as layer C (Malez 1965: 201). Various Upper Pleistocene sediments were labelled with letters from D to K (Malez 1965: 202-204, 206-208). Material remains of the Mousterian culture were found in layers $\mathrm{H}, \mathrm{I}$, and J. A few hundred stone artefacts were found along with bone retouchers, traces of fireplaces, and faunal remains (Malez 1965: 209, 211-212; 1981: 76). It is important to note that several non-diagnostic stone artefacts were found in layers D and F (Malez 1979a: 269; Miracle, Brajković 1992: 2), but their exact number is not known. Layer $\mathrm{K}$, which directly superseded the bedrock in the cave, contained neither faunal nor archaeological remains (Malez 1965: 214).

On the basis of the characteristics of layers and present fauna, Malez (1965: 220-221) dated layer J to the Riss/ Würm interglacial, while he positioned layers I and $\mathrm{H}$ to the Würm I stadial and Würm I/II interstadial, respectively. Today, it is difficult to entirely relate Malez's divison to the marine isotope stages, but Miracle and Brajković (1992: 8) concluded that the Riss/Würm interglacial, which Malez mentions, should be related to the MIS 5 e. Radiocarbon dating of charcoal samples from fireplaces from different sediments resulted in a minimum of 43.200 years BP for layer I and a minimum of 50.000 years BP for layer J (Malez 1981: 69; Vogel, Waterbolk 1972: 61). The results acquired from the revision of the fauna and data from sediments, which was conducted 
Slojevi A i B sadržavali su arheološke nalaze iz različitih razdoblja holocena (Malez 1965: 197, 199). Slojem C označena je siga koja je u dijelu špilje odjeljivala holocenske i pleistocenske slojeve (Malez 1965: 201). Različiti gornjopleistocenski sedimenti označeni su slovima od D do K (Malez 1965: 202-204, 206-208). U slojevima H, I i J pronađeni su materijalni ostaci mustjerske kulture. Uz nekoliko stotina kamenih izrađevina, pronađeni su koštani obrađivači, tragovi vatrišta i ostaci faune (Malez 1965: 209, 211-212; 1981: 76). Važno je napomenuti kako je nekoliko nedijagnostičkih kamenih izrađevina pronađeno i u slojevima D i F (Malez 1979a: 269; Miracle, Brajković 1992: 2), iako im se ne zna točan broj. U sloju K, koji je u špilji bio izravno nataložen na matičnu stijenu, nisu pronađeni ni ostaci faune ni arheološki nalazi (Malez 1965: 214).

Na temelju karakteristika slojeva i prisutne faune, Malez (1965: 220-221) je sloj J datirao u interglacijal Riss/Würm, dok je slojeve I i H smjestio u stadijal Würm I i interstadijal Würm I/II. Danas je teško Malezovu podjelu u potpunosti povezati sa stadijima izotopa kisika, ali su Miracle i Brajković (1992: 8) zaključili da se interglacijal Riss/Würm, koji navodi Malez, može povezati s MIS 5e. Radiokarbonska datiranja uzoraka ugljena iz vatrišta iz pojedinih sedimenata dala su rezultate od minimalno 43.200 godina prije sadašnjosti za sloj I te minimalno 50.000 godina prije sadašnjosti za sloj J (Malez 1981: 69; Vogel, Waterbolk 1972: 61). Rezultati dobiveni revizijom faune i podataka o sedimentima koju su napravili Miracle i Brajković (1992: 8-9) sugerirali su da sloj J valja datirati u početne faze zadnjega glacijala, odnosno u relativno topla razdoblja MIS 5 a (oko 80.000 godina prije sadašnjosti) ili 5c (oko 100.000 godina prije sadašnjosti). Ipak, nakon usporedbe faune s onom iz Krapine, koja je čvrsto datirana na 130.000 godina prije sadašnjosti (MIS 5e), te donjih slojeva Divjih baba I (MIS 5a-d), zaključilo se kako je sloj J ipak točnije datirati u MIS 5e (128.000 - 118.000 godina prije sadašnjosti), odnosno u razdoblje posljednjega interglacijala (Miracle, Brajković 2010: 219-220). Slojevi I i H okvirno su smješteni u MIS $5 d-5 a$ ili 4 , jer se smatralo da je sloj G koji je prekrivao H nastao u hladnim uvjetima MIS 4 ili MIS 3 kada je došlo do urušavanja stropa špilje ili okolnih padina, što je rezultiralo gotovo potpunim zatrpavanjem ulaza špilje (Miracle, Brajković 2010: 220).

\section{MATERIJAL I METODE}

U prostorima Zavoda za paleontologiju i geologiju kvartara HAZU-a pohranjeno je 604 kamenih nalaza. Nedostaju podaci o stratigrafskoj pripadnosti velike većine nalaza, izuzev manjega broja oruđa i jezgara objavljenih u ilustracijama u Malezovima radovima (Malez 1958; 1958/1959; 1967; 1974a; 1974b; 1979a; 1981). Iz navedenih je ilustracija također primijećeno da barem 14 (Malez 1958; 1979b; 1981) nalaza, mahom oruđa, danas nedostaje. Na određenim su nalazima izravno na površini napisane signature s oznakom "Veternica“ i brojem nalaza, dok se na nalazima pronađenim 1971. godine nalazi oznaka „Veternica 1971“ bez broja nalaza. Međutim, na većini je artefakata signatura bila napisana na naljepnicama koje su tijekom vremena otpale, a pojedine signature koje su bile napisane izravno na površinu arte- by Miracle and Brajković (1992: 8-9), suggested that layer J should be dated to the initial phases of the last glacial, or more precisely, to the relatively warm period of MIS $5 \mathrm{a}$ (about 80.000 years BP) or MIS 5c (about 100.000 years BP). Nevertheless, after the comparison of the fauna with that of Krapina, which is firmly dated to 130.000 years BP (MIS $5 e)$, and the lower levels of Divje babe I (MIS 5a-d), it was concluded that it was more accurate to date layer J to MIS 5 e (128.000 - 118.000 years BP), that is, to the last interglacial (Miracle, Brajković 2010: 219-220). Layers I and H were broadly dated to MIS $5 \mathrm{~d}-5 \mathrm{a}$ or 4 , because it was thought that layer $\mathrm{G}$, which superpositioned layer $\mathrm{H}$, was formed in the cold conditions of MIS 4 or MIS 3 when the cave ceiling or surrounding slopes collapsed, almost completely covering the cave entrance (Miracle, Brajković 2010: 220).

\section{MATERIAL AND METHODS}

In the Institute for Quaternary Paleontology and Geology of the Croatian Academy of Sciences and Arts 604 stone artefacts are stored. Except for a few tools and cores illustrated in the publications of Malez (1958; 1958/1959; 1967; 1974a; 1974b; 1979a; 1981), data about stratigraphical provenience is missing for most finds. Likewise, it was concluded from the mentioned illustrations that at least 14 finds (Malez 1958; 1979b; 1981), predominantly tools, are missing today. Certain finds have signatures that were written directly on the surface of the piece with the label "Veternica" and the find number, while the finds collected in 1971 have the label "Veternica 1971" written on them without the find number. However, most of the finds had labels written on stickers which fell off with time, and some labels that were written directly on the surface of the artefacts were partially erased and thus became illegible. On top of that, as the documentation linking the labels and the layers was not available, even the remaining finds with readable labels could not be linked to specific layers. Since the data about find provenience is missing, it is possible that a certain number of stone artefacts found in later layers ( $D$ and $F$ ) is mixed with the Mousterian artefacts, but according to available information (Malez 1979a: 269; Miracle, Brajković 1992: 2) it seems that these finds were few in number and non-diagnostic so their mixing with Middle Paleolithic artefacts would not significantly influence the quantitative and qualitative results of the lithic analysis. Owing to all these circumstances, the lithic assemblage from Veternica was analysed as a whole. But, before the analysis commenced, it was noticed that there were some natural pieces stored with the artefacts. These finds have no knapping traces and are too small to be used as hammers or raw material for future knapping, or they have traces of breakage which were formed by natural processes. Finds such as these were excluded and not analysed further. Furthermore, because of the contrast between the patina and fracture surface, it was noticed that some pieces have recent fractures which were probably formed during the excavation or after storage. Photographs and illustrations from earlier publications (Malez 1958) indicated that some of these pieces were joined, and some of them had traces of dried up glue, which further confirmed 
fakata djelomično su se izbrisale te postale nečitke. Povrh toga, kako nije bila dostupna dokumentacija koja povezuje signature i slojeve, čak ni preostali nalazi s čitkim signaturama nisu se mogli povezati s pojedinim slojevima. Budući da nedostaju podaci o podrijetlu nalaza, moguće jest da je određen broj kamenih izrađevina pronađenih u kasnijim slojevima ( $D$ i F) naknadno pomiješan s mustjerskim artefaktima, ali prema dostupnim podacima (Malez 1979a: 269; Miracle, Brajković 1992: 2) čini se da su bili malobrojni i nedijagnostički pa da njihova pomiješanost sa srednjopaleolitičkim artefaktima ne bi značajno utjecala na kvantitativne i kvalitativne rezultate litičke analize. Zbog svih navedenih okolnosti, litički je skup iz Veternice obrađen kao jedinstvena cjelina. Međutim, prije nego što se pristupilo analizi primijećeno je kako se među artefaktima nalaze i prirodni komadi. To su nalazi koji nemaju tragove lomljenja i premalih su dimenzija da bi se koristili kao čekići ili kao sirovina za buduće lomljenje ili pak imaju tragove lomljenja koji su nastali prirodnim putem. Ti su nalazi izdvojeni i nisu dalje analizirani. Nadalje, zbog kontrasta patine i površine loma primijećeno je kako neki ulomci izrađevina imaju recentne lomove koji su vjerojatno nastali tijekom iskopavanja ili nakon pohrane. Na fotografijama i ilustracijama iz ranijih radova (Malez 1958) primijećeno je kako su neki od tih nalaza bili spojeni, a neki su imali i sasušene tragove ljepila, što je dodatno potvrdilo da se uistinu radi o recentnim lomovima. Nalazi s recentnim lomovima koji su uspješno sastavljeni u daljnjoj su analizi tretirani kao cjelina kako bi se trenutno stanje skupa što uspješnije približilo stanju prije vađenja nalaza iz sedimenata. Stoga je ukupni broj pojedinačnih nalaza koji su analizirani, uz prethodno izuzimanje prirodnih komada, sveden na 569.

Skup litičkih izrađevina špilje Veternice podvrgnut je ponajprije tehnološkoj i tipološkoj analizi. Tehnološkoj analizi, koja se poglavito temeljila na pristupu lanca operacija, pridodana je analiza plohaka kako bi se utvrdio opseg i način pripreme udarne plohe te analiza tragova na dorzalnoj strani odbojka kako bi se utvrdili načini lomljenja koji nisu više prisutni na jezgrama (Baumler 1988: 262). Na temelju kriterija prema Baumleru (1988: 263) defnirani su sljedeći obrasci lomljenja: radijalan/subradijalan, jednosmjeran, dvosmjeran-okomit i ostalo. Kao predložak za izradu ljestvice tehnoloških kategorija za potrebe analize lanca operacija preuzeta je te modificirana ljestvica donesena $u$ radu Karavanić et al. (2008), a kategorije su definirane prema Inizan et al. (1999). Potrebno je razjasniti nekoliko upotrijebljenih kategorija radi jasnoće rezultata. Za razlikovanje između odbojaka i odbojčića te krhotina i otkrhaka uzeta je granica od $2 \mathrm{~cm}$ maksimalne dimenzije, pri čemu se komadi čija maksimalna dimenzija iznosi točno $2 \mathrm{~cm}$ svrstavaju također u odbojke, odnosno krhotine. Osim toga, razlikuju se tri kategorije odbojaka s okorinom. Prvotnim odbojcima je polovica ili više od polovice dorzalne strane prekriveno okorinom, dok drugotnim odbojcima okorina zauzima manje od polovice dorzalne strane. Noževi s prirodnim hrptom imaju jednu lateralnu stranu prekrivenu okorinom, a druga je neokorinska. Za potrebe provedbe tehnološke analize skup izrađevina podijeljen je na dvije skupine sirovina od kojih su that they were recently broken. Finds with recent breakages which were successfully refitted were further treated as single pieces to bring the condition of the assemblage closer to that before the finds were taken out of the sediments. Hence, the total number of individual finds analysed after excluding natural pieces was reduced to 569 .

The lithic assemblage of Veternica Cave was subjected first and foremost to a technological and typological analysis. The technological analysis, which was mainly based on the chaîne opératoire approach, was followed by the analysis of flake platforms to determine the scope and modes of the striking platform preparation and by the analysis of flake scars on the dorsal side of flakes to determine the modes of reduction which were not present on the cores any more (Baumler 1988: 262). On the basis of criteria according to Baumler (1988: 263), the following patterns of reduction were defined: radial/subradial, unidirectional, bidirectional-perpendicular, and other. A modified list of technological categories according to Karavanić et al. (2008) was used as the template to create such a list and the categories were defined according to Inizan et al. (1999). It is necessary to clarify some of the used categories in order for the results to be clear. For the differentiation between flakes and small flakes or chunks and small chunks, a maximum size limit of $2 \mathrm{~cm}$ of was used. Pieces with the maximum size of exactly $2 \mathrm{~cm}$ were also included into flakes or chunks. Also, three categories of flakes with cortex are recognized. Primary decortication flakes have a half or more of their dorsal side covered with cortex, while secondary decortication flakes are covered by cortex on less than half of the dorsal side. Naturally-backed knives have one lateral side covered with cortex while the other is non-cortical. For the purpose of the technological analysis, the lithic assemblage was divided into two groups of raw materials from which the artefacts were made. Group A included all the raw materials (chert, black eruptive, tuff, sandstone/lapilli tuff, silicified material, indeterminate) with conchoidal fracture as a common characteristic, while group $B$ included artefacts made from quartz. In fact, along with conchoidal fracture, there is often irregular fracture resulting from the reduction of quartz. Different physical characteristics of quartz with regard to cryptocrystalline raw materials cause difficulties in recognizing and interpreting quartz artefacts within a methodological framework based on the fracture mechanics of cryptocrystalline raw materials such as chert (de Lombera-Hermida, Rodriguez-Rellán 2016: 2; Driscoll 2010: 3). Therefore, in order to better define the chaîne opératoire of quartz artefacts, a separate list of technological categories was created. To avoid certain problems of classifying quartz artefacts, some technological categories in group $B$ were defined differently. Primary and secondary decortication flakes and naturally-backed knives were included together in the category of flakes with cortex. The typological analysis encompassed all the artefacts with retouch and the category of naturally-backed knives (Debénath, Dibble 1994). Two new types were added to Bordes's basic types: retouched piece (number 64) and tool fragment (number 65). A retouched piece is an artefact with marginal, discon- 
napravljene. Skupina A obuhvatila je sve sirovine (rožnjak, crni eruptiv, tuf, pješčenjak/lapilni tuf, silicificirani materijal, neodređeno) kojima je zajednička karakteristika školjkasti lom, dok su u skupinu B svrstane sve izrađevine napravljene od kvarca bjelutka. Naime, uz školjkaste lomove, pri redukciji kvarca često dolazi i do nepravilnih lomova, a različita fiziklana svojstva u odnosu na kriptokristalinične sirovine uvjetuje otežano prepoznavanje i interpretaciju kvarcnih izrađevina u metodološkom okviru koji se temelji na mehanici loma kriptokristaliničnih sirovina poput rožnjaka (de Lombera-Hermida, Rodriguez-Rellán 2016: 2; Driscoll 2010: 3). Stoga, kako bi se bolje definirao lanac operacija kvarcnih izrađevina, napravljena je i zasebna ljestvica tehnoloških kategorija. Kako bi se izbjeglo određene probleme kategoriziranja kvarcnih izrađevina, neke tehnološke kategorije u skupini B različito su definirane. Prvotni i drugotni odbojci te noževi s prirodnim hrptom zajedno su svrstani u kategoriju odbojaka s okorinom. Tipološka analiza obuhvatila je sve dodatno obrađene izrađevine i kategoriju prirodni nož hrptenjak (Debénath, Dibble 1994). Osnovnim Bordesovim tipovima pridodana su dva nova tipa, komad s obradbom (broj 64) i ulomak oruđa (broj 65). Komad s obradbom je artefakt sa sitnom, isprekidanom i/ili djelomičnom obradbom koja nije karakteristična za nijedan klasično definirani tip oruđa. Provedena je i preliminarna sirovinska analiza, odnosno podjela izrađevina u sirovinske kategorije prema makroskopskim obilježjima. ${ }^{1}$ Pritom treba imati na umu probleme pogrešnogs pripisivanja koji se vežu uz provedbu makroskopske sirovinske analize bez prethodne izrade izbrusaka (Blaser et al. 2002: 390). Naime, moglo je doći do određenih odstupanja zbog toga što različite sirovine mogu imati slične makroskopske karakteristike. Uz to, na artefaktima s okorinom bilježila se i vrsta okorine, na temelju modificirane podjele (prema Perhoč, Altherr 2011: 17-18).

\section{REZULTATI ANALIZE}

\subsection{Tehnološka analiza}

\subsubsection{Učestalost tehnoloških kategorija}

U sirovinskoj skupini A (sl. 3; tab. 1) najzastupljenija tehnološka kategorija su ulomci odbojaka s 33,4\%. Međutim, kako ulomci odbojaka nisu nužno tehnološka kategorija, najzastupljenija tehnološka kategorija u užem smislu jest odbojak čiji postotak u litičkome skupu skupine A iznosi $25,2 \%$. Zatim slijede drugotni odbojci s $8,2 \%$, krhotine $s$ okorinom sa 7,5\%, otkrhci 5,9\%. Drugotnim odbojcima mogu se na temelju količine okorine pridružiti i noževi s prirodnim hrptom, pa zajednički udio obje kategorije iznosi $9,5 \%$. Sve ostale kategorije zastupljene su s manje od $5 \%$. Relativno je mali udio prvotnih odbojaka s $2,3 \%$. Jezgre i ulomci jezgara također su slabo zastupljeni, ukupno u 13 primjeraka, što je manje od 5\%. Od izrađevina sirovinske skupine A dodatno je obrađeno 67 izrađevina, odnosno $22 \%$. Kategorije s najvećim udjelom obrađenih izrađevina su noževi s prirodnim hrptom, zatim drugotni odbojci i odbojci (bez okorine). Premda je gotovo petina ulomaka od-

1 Kategorije sirovina definirane su uz pomoć Dražena Kurtanjeka s Geološkoga odsjeka Prirodoslovno-matematičkog fakulteta Sveučilišta u Zagrebu. Pri definiranju koristila se lupa s povećanjem od x10. tinuous, or partial retouch, which is not characteristic of any classically defined tool type. A preliminary raw material analysis was also conducted - more precisely, a division of artefacts into raw material categories according to macroscopic features.' Here we must keep in mind the problems of erroneous attribution associated with doing macroscopic raw material analysis without previously making thin-sections (Blaser et al. 2002: 390). In fact, it is possible that certain discrepancies were caused by different raw materials having similar macroscopic characteristics. The type of cortex on the artefacts was recorded on the basis of a modified division by Perhoč, Altherr (2011: 17-18).

\section{RESULTS OF THE ANALYSIS \\ 6.1. Technological analysis}

\subsubsection{Frequency of technological categories}

Flake fragments are the most frequent technological category in raw material group A (Fig. 3; Tab. 1) with 33.4\%.

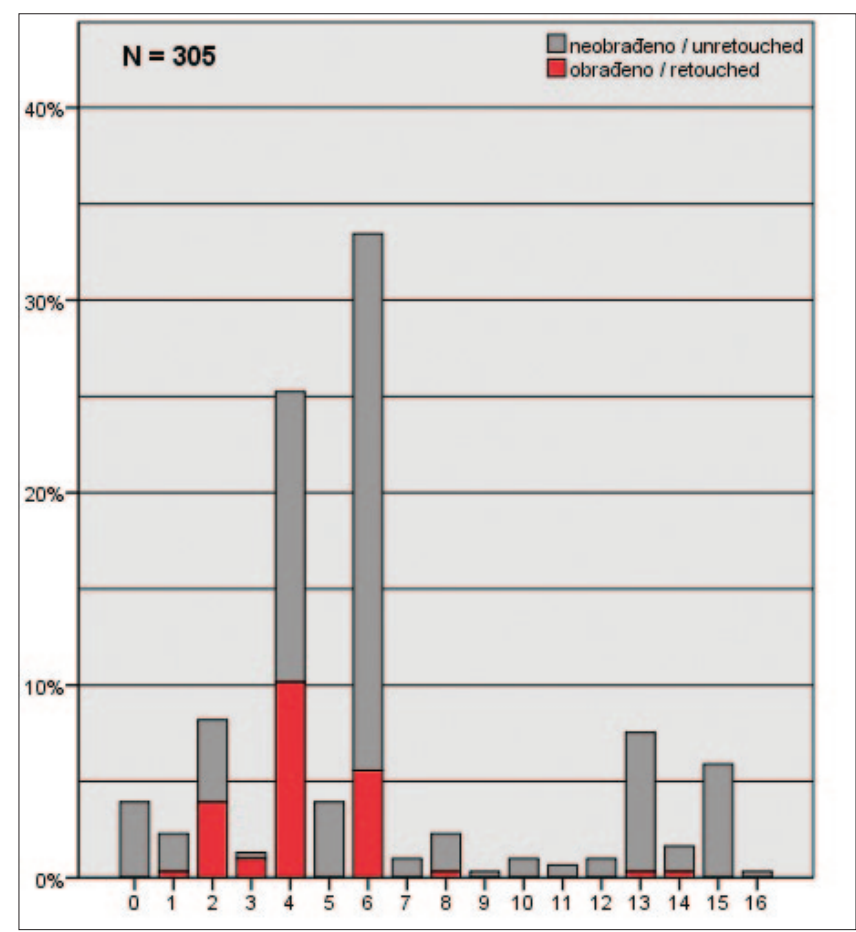

SI. 3 Dijagram zastupljenosti tehnoloških kategorija sirovinske skupine A (rožnjak, crni eruptiv, tuf, pješčenjak/lapilni tuf, silicificirani materijal, neodređeno): 0. oblutak; 1. prvotni odbojak; 2. drugotni odbojak; 3. nož s prirodnim hrptom; 4. odbojak; 5. odbojčić; 6. ulomak odbojka; 7. dotjerujući odbojak jezgre; 8 . jezgra s okorinom; 9. Jezgra; 10 . ulomak jezgre s okorinom; 11 . ulomak jezgre; 12 . odbojak od dodatne obradbe; 13. krhotina s okorinom; 14. krhotina; 15. otkrhak; 16. neodredivo (izradio: M. Banda, 2019.)

Fig. 3 Diagram showing the presence of technological categories of raw material group $A$ (chert, black eruptive, sandstone/lapilli tuff, silicified material, indeterminate): 0. pebble; 1. primary flake; 2. secondary flake; 3. naturally-backed knife; 4. flake; 5. small flake; 6. flake fragment; 7. retouch core flake; 8. core with cortex; 9. core; 10. core fragment with cortex; 11. core fragment; 12. retouch flake; 13. chunk with cortex; 14. chunk; 15. small chunk; 16. indeterminate (made by: M. Banda 2019)

1 Raw material categories were defined with the help of Dražen Kurtanjek from the Department of Geology of the Faculty of Science, University of Zagreb. A 10x magnification loupe was used. 


\begin{tabular}{|c|c|c|c|c|c|c|}
\hline \multirow{2}{*}{$\begin{array}{l}\text { Tehnološke kategorije (sirovinska skupina A) / } \\
\text { Technological categories (raw material group A) }\end{array}$} & \multicolumn{2}{|c|}{ neobrađeno / unretouched } & \multicolumn{2}{|c|}{ obrađeno / retouched } & \multicolumn{2}{|c|}{ Ukupno / Total } \\
\hline & $\mathrm{N}$ & $\%$ & $\mathrm{~N}$ & $\%$ & $\mathrm{~N}$ & $\%$ \\
\hline 0. oblutak / pebble & 12 & $3.9 \%$ & 0 & $0.0 \%$ & 12 & $3.9 \%$ \\
\hline 1. prvotni odbojak / primary flake & 6 & $2.0 \%$ & 1 & $0.3 \%$ & 7 & $2.3 \%$ \\
\hline 2. drugotni odbojak / secondary flake & 13 & $4.3 \%$ & 12 & $3.9 \%$ & 25 & $8.2 \%$ \\
\hline 3. nož s prirodnim hrptom / naturally-backed knife & 1 & $0.3 \%$ & 3 & $1.0 \%$ & 4 & $1.3 \%$ \\
\hline \begin{tabular}{|c|} 
4. odbojak / flake \\
\end{tabular} & 46 & $15.1 \%$ & 31 & $10.2 \%$ & 77 & $25.2 \%$ \\
\hline 5. odbojčić / small flake & 12 & $3.9 \%$ & 0 & $0.0 \%$ & 12 & $3.9 \%$ \\
\hline 6. ulomak odbojka / flake fragment & 85 & $27.9 \%$ & 17 & $5.6 \%$ & 102 & $33.4 \%$ \\
\hline 7. dotjerujući odbojak jezgre / retouch core flake & 3 & $1.0 \%$ & 0 & $0.0 \%$ & 3 & $1.0 \%$ \\
\hline 8. jezgra s okorinom / core with cortex & 6 & $2.0 \%$ & 1 & $0.3 \%$ & 7 & $2.3 \%$ \\
\hline 9. jezgra / core & 1 & $0.3 \%$ & 0 & $0.0 \%$ & 1 & $0.3 \%$ \\
\hline $\begin{array}{l}\text { 10. ulomak jezgre s okorinom / core fragment with } \\
\text { cortex }\end{array}$ & 3 & $1.0 \%$ & 0 & $0.0 \%$ & 3 & $1.0 \%$ \\
\hline \begin{tabular}{|l|} 
11. ulomak jezgre / core fragment \\
\end{tabular} & 2 & $0.7 \%$ & 0 & $0.0 \%$ & 2 & $0.7 \%$ \\
\hline 12. odbojak od dodatne obradbe / retouch flake & 3 & $1.0 \%$ & 0 & $0.0 \%$ & 3 & $1.0 \%$ \\
\hline 13. krhotina s okorinom / chunk with cortex & 22 & $7.2 \%$ & 1 & $0.3 \%$ & 23 & $7.5 \%$ \\
\hline 14. krhotina / chunk & 4 & $1.3 \%$ & 1 & $0.3 \%$ & 5 & $1.6 \%$ \\
\hline 15. otkrhak / small chunk & 18 & $5.9 \%$ & 0 & $0.0 \%$ & 18 & $5.9 \%$ \\
\hline 16. neodredivo / indeterminate & 1 & $0.3 \%$ & 0 & $0.0 \%$ & 1 & $0.3 \%$ \\
\hline Ukupno / Total & 238 & $78.0 \%$ & 67 & $22.0 \%$ & 305 & $100.0 \%$ \\
\hline
\end{tabular}

Tab. 1 Tehnološke kategorije sirovinske skupine A (rožnjak, crni eruptiv, tuf, pješčenjak/lapilni tuf, silicificirani materijal, neodređeno) (izradio: M. Banda, 2019.)

Tab. 1 Technological categories of raw material group A (chert, black eruptive, sandstone/lapilli tuff, silicified material, indeterminate) (made by: M. Banda, 2019)

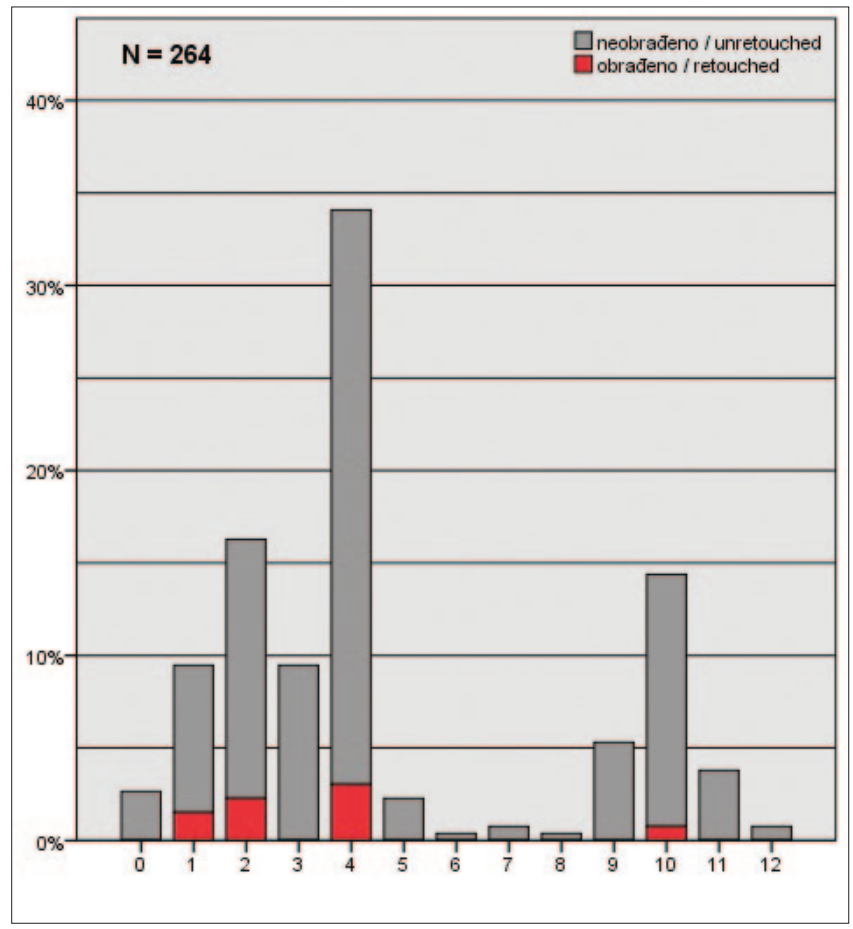

SI. 4 Dijagram zastupljenosti tehnoloških kategorija sirovinske skupine B (kvarc): 0. oblutak; 1. odbojak s okorinom; 3. odbojčić; 4. ulomak odbojka; 5 . jezgra s okorinom; 6. jezgra; 7. jezgra na odbojku; 8. ulomak jezgre; 9 . krhotina s okorinom; 10. krhotina; 11. otkrhak; 12. neodredivo (izradio: M. Banda, 2019.)

Fig. 4 Diagram showing the presence of technological categories of raw material group $B$ (quartz): 0. pebble; 1. flake with cortex; 2. flake; 3. small flake; 4 . flake fragment; 5 . core with cortex; 6 . core; 7. core on flake; 8. core fragment; 9. chunk with cortex; 10. chunk; 11. small chunk; 12. indeterminate (made by: M. Banda, 2019)
However, as flake fragments are not necessarily a technological category, flakes are the most frequent technological category sensu stricto, making up $25.2 \%$ of the lithic assemblage of group A. They are followed by secondary decortication flakes (8.2\%), chunks with cortex (7.5\%), and small chunks (5.9\%). Considering the amount of cortex, we can add naturally-backed knives to secondary decortication flakes so the share of both equals $9.5 \%$. All the remaining categories amount to less than $5 \%$. The share of primary decortication flakes is relatively small: $2.3 \%$. Cores and core fragments are also poorly represented: 13 pieces in total, which is less than $5 \%$. Among the artefacts from raw material group A, 67 pieces or $22 \%$ are retouched. The categories with the largest portions of retouched artefacts are naturally-backed knives, secondary decortication flakes, and flakes (without cortex). Although almost a fifth of flake fragments are retouched, the fragmentation of flakes over time altered the initial ratio of whole retouched pieces to unretouched pieces, so the portion of retouched flake fragments probably does not reflect well the ratio at the time of artefact deposition.

The analysis of the chaîne opératoire of raw material group B (Fig. 4; Tab. 2) (quartz artefacts) has shown that flake fragments are the most numerous category, making up $34.1 \%$ of all the artefacts in this group. These are followed by flakes and chunks at $16.3 \%$ and $14.4 \%$, respectively, and flakes with cortex and small flakes are present at $9.5 \%$. Chunks with cortex have a share of $5.3 \%$, while all the remaining categories total less than $5 \%$. When compared to 


\begin{tabular}{|c|c|c|c|c|c|c|}
\hline $\begin{array}{c}\text { Tehnološke kategorije (sirovinska skupina B) } \\
\text { / Technological categories (raw material } \\
\text { group B) }\end{array}$ & $\mathrm{N}$ & $\%$ & $\mathrm{~N}$ & $\%$ & \multicolumn{2}{|c|}{ Ukupno / Total } \\
\cline { 2 - 7 } & & & & & $\mathrm{N}$ \\
\hline 0. oblutak / pebble & 7 & $2.7 \%$ & 0 & $0.0 \%$ & 7 & $2.7 \%$ \\
\hline 1. odbojak s okorinom / flake with cortex & 21 & $8.0 \%$ & 4 & $1.5 \%$ & 25 & $9.5 \%$ \\
\hline 2. odbojak / flake & 37 & $14.0 \%$ & 6 & $2.3 \%$ & 43 & $16.3 \%$ \\
\hline 3. odbojčić / small flake & 25 & $9.5 \%$ & 0 & $0.0 \%$ & 25 & $9.5 \%$ \\
\hline 4. ulomak odbojka / flake fragment & 82 & $31.1 \%$ & 8 & $3.0 \%$ & 90 & $34.1 \%$ \\
\hline 5. jezgra s okorinom / core with cortex & 6 & $2.3 \%$ & 0 & $0.0 \%$ & 6 & $2.3 \%$ \\
\hline 6. jezgra / core & 1 & $0.4 \%$ & 0 & $0.0 \%$ & 1 & $0.4 \%$ \\
\hline 7. jezgra na odbojku / core on flake & 2 & $0.8 \%$ & 0 & $0.0 \%$ & 0 & $0.8 \%$ \\
\hline 8. ulomak jezgre / core fragment & 1 & $0.4 \%$ & 0 & $0.0 \%$ & 1 & $0.4 \%$ \\
\hline 9. krhotina s okorinom / chunk with cortex & 14 & $5.3 \%$ & 0 & $0.0 \%$ & 14 & $5.3 \%$ \\
\hline 10. krhotina / chunk & 36 & $13.6 \%$ & 2 & $0.8 \%$ & 38 & $14.4 \%$ \\
\hline 11. otkrhak / small chunk & 10 & $3.8 \%$ & 0 & $0.0 \%$ & 10 & $3.8 \%$ \\
\hline 12. neodredivo / indeterminate & 4 & $0.8 \%$ & 0 & $0.0 \%$ & 4 & $0.8 \%$ \\
\hline Ukupno / Total & 244 & $92.4 \%$ & 20 & $7.6 \%$ & 264 & $100.0 \%$ \\
\hline
\end{tabular}

Tab. 2 Tehnološke kategorije sirovinske skupine B (kvarc) (izradio: M. Banda, 2019.)

Tab. 2 Technological categories of raw material group B (quartz) (made by: M. Banda, 2019)

bojaka obrađena, fragmentacija odbojaka tijekom vremena izmijenila je prvobitni brojčani odnos cjelovitih obrađenih i neobrađenih komada, pa udio obrađenih ulomaka odbojaka vjerojatno ne odražava dobro stvaran odnos u vrijeme deponiranja izrađevina.

Analizom lanca operacija sirovinske skupine B (sl. 4; tab. 2) (kvarcne izrađevine) utvrdilo se da je najzastupljenija kategorija ulomak odbojka koji čini 34,1\% svih izrađevina. Slijede odbojci i krhotine sa $16,3 \%$ i $14,4 \%$, a odbojci s okorinom i odbojčići su jednako zastupljeni s 9,5\%. Krhotine s okorinom imaju udio od 5,3\%, dok je udio svake preostale kategorije manji od $5 \%$. U odnosu na lanac operacija sirovinske skupine A, razlika u broju odbojaka s okorinom i odbojaka bez okorine je ponešto manja, čak i kada se u skupini A prvotni odbojci, drugotni odbojci i noževi s prirodnim hrptom, odnosno sve kategorije odbojaka s okorinom ubroje zajedno. Od svih izrađevina sirovinske skupine B, samo je 20 primjeraka ili 7,6\% obrađeno. Oruđa su najčešće napravljena na ulomcima odbojaka, zatim na odbojcima, odbojcima s okorinom i krhotinama, dok druge proizvodne kategorije ne sadrže obrađene primjerke.

\subsubsection{Jezgre}

U sirovinskoj skupini A prisutno je osam primjeraka jezgara, a od toga broja čak ih sedam ima na sebi sačuvanu okorinu. Prema obrascu lomljenja, četiri primjerka pripadaju centripetalnim jezgrama (T. 1: 5; 4: 6; 5: 4-5), tri nepravilnim jezgrama s višesmjernim lomljenjem (T. 2: 1; 5: 2), dok je jedna jezgra svrstana u tip s nasuprotnim lomljenjem (T. 6: 7). Okorina prisutna na jezgrama u potpunosti pripada valutičnome tipu, pa svjedoči da su jezgre isključivo napravljene od oblutaka. Unutar pojedinih skupina jezgara prema obrascu lomljenja uočavaju se ponekad određene razlike. Centripetalne jezgre razlikuju se međusobno u pogledu veličine i jesu li lomljene $s$ jedne ili dvije strane. Tri centripetalne jezgre lomljene su s dvije nasuprotne strane, the chaîne opératoire of group A, the difference in number between flakes with cortex and flakes without cortex is somewhat smaller, even if we lump together the primary decortication flakes, secondary decortication flakes, naturallybacked knives or all flake categories with cortex in group $A$. Of all the artefacts from group B, only 20 pieces or $7.6 \%$ are retouched. Tools were most commonly made of flake fragments, flakes, flakes with cortex, and chunks, while other categories do not contain retouched pieces.

\subsubsection{Cores}

In raw material group $A$, there are eight cores, seven of which have a preserved cortex on them. According to the pattern of reduction, four pieces belong to centripetal cores (PI. 1: 5; 4: 6; 5: 4-5), three to irregular cores with multidirectional reduction (PI. 2: 1; 5: 2), and one core is classified as the type with opposite reduction (PI. 6: 7). The remnants of cortex on the cores wholly belong to the cobble type and indicate that the cores were exclusively made from cobbles. Certain differences are sometimes noticeable within particular core types according to reduction patterns. Centripetal cores differ among each other in size and in whether they were flaked on one or both sides. Three centripetal cores were flaked from two opposite sides, only one has flake scars on one side, and one is covered in cortex. Furthermore, these cores are, on average, smaller than the other types, and two pieces are maximally exhausted. Irregular cores with multidirectional reduction are generally globular and not fully exhausted, and one piece has been retouched into a tool (PI. 5: 2). The only instance of a core with opposite reduction has long flake scars flaked from opposite platforms. Along with the mentioned cores, five pieces of core fragments were recognized, of which three have cortex. Unidirectional flaking of small flakes has been recognized in two pieces, bidirectional flaking in one, while it is not possi- 
a samo jedna ima tragove lomljenja s jedne strane, dok joj je druga prekrivena okorinom. Nadalje, one su u prosjeku manje od ostalih vrsta jezgara, a dva primjerka su maksimalno iskorištena. Nepravilne jezgre s višesmjernim lomljenjem u pravilu su globularne te nisu u potpunosti iskorištene, a od jedne je čak dodatnom obradbom oblikovano oruđe (T. 5: 2). Jedini primjerak jezgre s nasuprotnim lomljenjem ima tragove duguljastih odbojaka odlomljenih od dviju nasuprotnih ploha. Uz navedene cjelovite jezgre, prepoznato je i pet primjeraka ulomaka jezgara, od kojih tri imaju okorinu. Na dvama primjercima utvrđeno je istosmjerno lomljenje malih odbojaka, na jednome centripetalno dvostrano lomljenje, dok ostalim primjercima nije moguće pouzdano odrediti obrazac lomljenja.

Jezgre sirovinske skupine B zastupljene su u devet primjeraka. Od navedenih jezgara šest ima sačuvanu okorinu, jedna jezgra nema okorinu, a dvije jezgre su napravljene na odbojcima. Vrsta okorine ukazuje da su sve jezgre s okorinom napravljene od oblutaka. Prema obliku i obrascu redukcije šest jezgara pripada klinastome tipu (T. 7: 1-3, 5-6). Takve jezgre klinastoga su oblika, imaju trokutasti presjek, a nastale su redukcijom oblutka uglavnom ukrug po okorinskoj plohi, dok je na jednome primjerku primijećeno i lomljenje jednoga odbojka nasuprot okorinskoj plohi u završnoj fazi iskorištavanja jezgre (T. 7: 6). Uz navedene, zabilježena je i jedna mala jezgra bez okorine s tragom bipolarnoga Iomljenja (T. 7: 4). Dvije jezgre na odbojcima lomljene su jednosmjerno, pri čemu je ventralna strana odbojka poslužila kao udarna ploha. Jednosmjerno lomljenje zabilježeno je i na jedinome ulomku jezgre iz sirovinske skupine $B$.

\subsubsection{Plošci}

Analiza plohaka obuhvatila je 208 odbojaka i proksimalnih ulomaka odbojaka iz sirovinske skupine A te 163 iz skupine B. Najveći broj primjeraka iz skupine A ima glatke plohke $(33,2 \%)$, ali brojni su i višeplošni $(21,6 \%)$ i okorinski $(16,3 \%)$ oblici. Dvopovršinski i linearni plošci podjednako su zastupljeni, sa 7,7\%. Točkasti plošci čine udio od 2,9\%, a neodredivi oblici čak $10,6 \%$ svih plohaka skupine A.

Među kategorijama plohaka skupine B također su najzastupljeniji glatki plošci, ali je njihov udio od $63,2 \%$ znatno veći nego u skupini A. Iza njih najbrojniju kategoriju čine okorinski plošci sa $17,8 \%$ pa zajedno s glatkim plošcima predstavljaju četiri petine (81\%) svih plohaka skupine B. Od preostalih kategorija najbrojniji su neodredivi oblici $(8,6 \%)$, dok se svi drugi javljaju u znatno manjim postocima.

\subsubsection{Analiza smjerova tragova lomljenja na dorzal- noj strani odbojaka}

Za provedbu analize obrasca smjerova tragova na dorzalnoj strani odbojaka izdvojeno je 53 odbojka iz sirovinske skupine A koji su veći od $2 \mathrm{~cm}$ i na svojoj dorzalnoj strani imaju barem tri traga ranijih odbojaka (Baumler 1988: 265). Analiza obrazaca smjerova nije napravljena za odbojke sirovinske skupine $B$ zato što fizikalna svojstva kvarca otežavaju prepoznavanje tragova lomljenja, a napose njihovih smjerova. Na temelju prethodnoga pregleda materijala izdvojeni su sljedeći obrasci: radijalan/subradijalan, jednosmjeran, ble to determine the reduction pattern for the remainder.

In raw material group $B$, cores are present in nine pieces. Six of these cores have cortex, one does not, and two cores are made of flakes. Cortex type shows that all cores with cortex are made from cobbles or pebbles. Considering the shape and reduction pattern, six cores belong to the cobble-wedge type (PI. 7: 1-3, 5-6). These cores are wedgeshaped, have a triangular cross-section, and were made by circular reduction of a cobble from a cortical striking platform. One piece displays a knapping of a flake opposite to the cortical platform in the final stage of exploitation (PI. 7: 6). Aside from these cores, there was a small core without cortex and scar from bipolar knapping (PI. 7: 4). Two cores on flakes were unidirectionally flaked, and the ventral side of the flake was used as a striking platform. Unidirectional flaking was recorded for the only instance of a core fragment in raw material group $B$.

\subsubsection{Flake platforms}

The analysis of flake platforms included 208 flakes and proximal flake fragments from raw material A and 163 from group $B$. The largest number of pieces from group $A$ has flat platforms (33.2\%), but there are also numerous faceted (21.6\%) and cortical forms (16.3\%). Dihedral and linear platforms are present at $7.7 \%$. Punctiform platforms have a share of $2.9 \%$ and indeterminate forms have $10.6 \%$ of all the platforms of group A.

Among the categories of flake platforms in group $B$, flat platforms are likewise the most numerous, but their portion of $63.2 \%$ is significantly greater than in group A. Cortical platforms are the second most numerous category at $17.8 \%$. Together with flat platforms, they represent four-fifths $(81 \%)$ of all group B platforms. Of the remaining categories, indeterminate forms are the most numerous (8.6\%), while all other types are present in significantly smaller percentages.

\subsubsection{Analysis of flake scar orientation on dorsal sides of flakes}

For the analysis of flake scar orientation patterns on dorsal sides of flakes, 53 flakes were selected from raw material group A, all larger than $2 \mathrm{~cm}$ and having at least three flake scars on their dorsal side (Baumler 1988: 265). The analysis of orientation patterns was not conducted for the flakes from raw material group $B$, because the physical characteristics of quartz hinder the recognition of flake scars, and especially their direction. On the basis of a prior examination of the material, the following patterns were determined: radial/subradial, unidirectional, bidirectional-perpendicular, and remaining. The analysis determined that the most numerous pattern of flake scars is radial/subradial, more precisely that which corresponds to centripetal reduction. It is followed by unidirectional and bidirectional-perpendicular patterns, at $26.4 \%$. The remaining patterns total $11.3 \%$. The prevalence of the radial/subradial pattern coincides with the portion of centripetal cores among all the cores of group A. On the other hand, there is no correspondingly high percentage of the unidirectional pattern in the core sam- 
dvosmjeran-okomit i ostali. Analizom je utvrđeno kako je najzastupljeniji obrazac tragova radijalan/subradijalan, odnosno onaj koji odgovara centripetalnome lomljenju. Slijede podjednako zastupljeni jednosmjerni i dvosmjerni-okomit obrazac tragova s $26,4 \%$, dok udio ostalih tipova obrazaca iznosi 11,3\%. Prevladavanje radijalnog/subradijanog obrasca poklapa se s udjelom centripetalnih jezgara među jezgrama sirovinske skupine A. S druge strane, visoki udio istosmjernoga obrasca nije odgovarajuće zastupljen u kategoriji jezgara. Dvosmjerni-okomiti obrasci najčešće se javljaju u obliku istosmjernih tragova uz koje se javlja jedan trag čiji je smjer okomit na njihov. Među jezgrama i ulomcima jezgara ne može se pronaći nijedan oblik koji je lomljen isključivo na taj način.

\subsection{Tipološka analiza}

Tipološka analiza obuhvatila je 87 kamenih oruđa iz obiju sirovinskih skupina, koja čine oko 15\% ukupnoga udjela svih litičkih izrađevina iz Veternice (tab. 3). Najzastupljeniji tipovi su jednostrana ravna (T. 1: 1, 3; 5: 1) i jednostrana izbočena strugala (T. 1: 2; 3: 3; 4: 1-2; 5: 2). Jedina oruđa koja imaju udio veći od $10 \%$ su jednostrana ravna strugala s $11,5 \%$, dok jednostrana izbočena strugala čine udio od 9,2\%. Malo slabije su zastupljeni drugi oblici strugala, ali se ipak pojedini tipovi poput poprečnih izbočenih strugala (T. 3: 1; 6: 9), strugala na ravnoj strani (T. 4: 4) i izmjeničnih strugala (T. 6: 2) javljaju pojedinačno s oko $5 \%$. Mustjerski šiljci (T. 1: 4; 3 : $2,4)$ zabilježeni su u četiri primjerka, odnosno 4,6\%. Nešto zastupljeniji su udupci (T. 5: 3) i nazupci, kojih redom ima $6,9 \%$ i $5,7 \%$. Sa $6,9 \%$ zastupljeni su i komadi s obradbom, kao i ulomci oruđa koje se zbog fragmentiranosti nije moglo pripisati drugim klasično definiranim tipovima.

Kada se tipovi oruđa grupiraju u veće skupine, kako je podijeljeno u Débenath, Dibble (1994), dobiva se jasniji uvid u odnos između pojedinih kategorija oruđa (sl. 5; tab. 4). Različiti tipovi strugala čine najbrojniju skupinu s 43 primjerka ili 49,4\% udjela svih oruđa. Druga najbrojnija skupina su gornjopaleolitički tipovi (grebalo, dubilo, svrdlo, svrdlenica, nož hrptenjak, hrbasti nož, prirodni nož hrptenjak, strugalica) s 13 primjeraka ili 14,9\%. Neznatno manje brojnija skupina obuhvaća udupke i nazupke s 11 komada ili 12,6\%. Tehnološki definirani tipovi javljaju se samo u jednom primjerku (prirodni nož hrptenjak), odnosno s 1,1\%. Udio šiljaka, komada s obradbom, ulomaka oruđa i raznih tipova isti je kao u detaljnoj raščlambi tipova.

\subsection{Analiza sirovine}

Analizom sirovine dobiven je udio pojedinih kategorija sirovina u litičkome skupu (tab. 5). Najbrojnija kategorija sirovine obuhvaća izrađevine napravljene od kvarca, s 264 utvrđena primjerka ili 46,4\%. Druga najzastupljenija kategorija s $27,9 \%$ su različiti varijeteti rožnjaka. Kategorije crnoga eruptiva, pješčenjaka/lapilnog tufa i silicificiranoga materijala slično su zastupljene, između 5,4 i 6,3\%, dok udio tufova iznosi samo 1,9\%. Izrađevine kojima se nije mogla utvrditi sirovina čine udio od $6 \%$. Budući da većini nalaza nedostaju stratigrafski podaci, nemoguće je utvrditi koliko su se srednjopaleolitički slojevi Veternice razlikovali po udjelu pojedi- ple. Bidirectional-perpendicular patterns generally have more unidirectional scars with one perpendicular flake scar. Among the cores and core fragments, there are no pieces reduced exclusively in this mode.

\subsection{Typological analysis}

The typological analysis encompassed 87 stone tools from both raw material groups, which make up about 15\% of the entire lithic assemblage of Veternica (Tab. 3). The most represented types are straight (PI 1: 1, 3; 5: 1) and convex (PI. 1: 2; 3: 3; 4: 1-2; 5: 2) sidescrapers. The only tools with a portion larger than $10 \%$ are straight sidescrapers at $11.5 \%$, while the percentage of convex sidescrapers is $9.2 \%$. Other tool types are fewer, but some of them, such as transverse scrapers (PI. 3: 1; 6: 9), scrapers on interior surface (PI. 4: 4), and alternate scrapers (PI. 6: 2), account for about 5\% each. Mousterian points (PI. 1: $4 ; 3: 2,4)$ have been recognized in four pieces or $4.6 \%$. Notches (PI. 5: 3 ) and denticulates are represented somewhat better, at $6.9 \%$ and $5.7 \%$, respectively. Retouched pieces and tool fragments, which cannot be attributed to other classically defined types because of fragmentation, are both present at $6.9 \%$.

When tool types are grouped into larger groups, like the division of Débenath, Dibble (1994), we gain a clearer insight into the relations of different tool categories (Fig. 5; Tab. 4). Different types of scrapers make up the most numerous group at $49.4 \%$ of all tools with 43 pieces. Upper Paleolithic types (endscraper, burin, borer, atypical borer, backed knife, atypical backed knife, raclette) are the second most numerous group at $14.9 \%$ with 13 pieces. A slightly less numerous group contains notches and denticulates at $12.6 \%$ with 11 pieces. There is only one instance of technologically defined tools (a naturally-backed knife), accounting for $1.1 \%$. The percentages of points, retouched pieces, tool

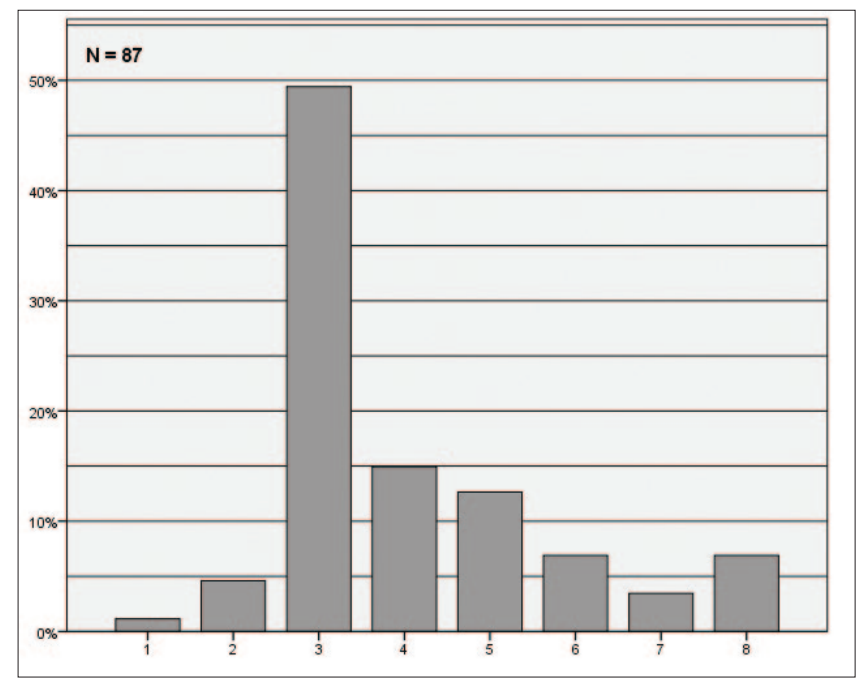

SI. 5 Dijagram zastupljenosti grupiranih tipova oruđa: 1. tehnološki definirani tipovi (prirodni nož hrptenjak); 2. šiljci; 3. strugala; 4. gornjopaleolitički tipovi; 5. udupci i nazupci; 6 . komadi s obradbom; 7. razno; 8 . ulomci oruđa (izradio: M. Banda, 2019.)

Fig. 5 Diagram showing the presence of grouped tool types: 1. technologically defined types (naturally-backed knife); 2. points; 3. scrapers; 4. Upper Paleolithic types; 5. notches and denticulates; 6 . retouched pieces; 7. miscellaneous; 8 . tool fragments (made by: M. Banda, 2019) 


\begin{tabular}{|c|c|c|c|}
\hline $\begin{array}{l}\text { Broj tipa prema Bordsu / Num- } \\
\text { ber of type according to Bordes }\end{array}$ & Tipovi oruđa / Tool types & $\mathbf{N}$ & $\%$ \\
\hline 6 & mustjerski šiljak / Mousterian point & 4 & $4.6 \%$ \\
\hline 9 & jednostrano ravno strugalo / single straight sidescraper & 10 & $11.5 \%$ \\
\hline 10 & jednostrano izbočeno strugalo / single convex sidescraper & 8 & $9.2 \%$ \\
\hline 11 & jednostrano udubljeno strugalo / single concave sidescraper & 2 & $2.3 \%$ \\
\hline 13 & dvostruko ravno-izbočeno strugalo / double straight-convex sidescraper & 1 & $1.1 \%$ \\
\hline 15 & dvostruko izbočeno strugalo / double convex sidescraper & 1 & $1.1 \%$ \\
\hline 18 & primično strugalo / convergent scraper & 2 & $2.3 \%$ \\
\hline 21 & kutno strugalo / déjeté scraper & 3 & $3.4 \%$ \\
\hline 23 & poprečno izbočeno strugalo / transverse convex scraper & 5 & $5.7 \%$ \\
\hline 24 & poprečno udubljeno strugalo / transverse concave sidescraper & 1 & $1.1 \%$ \\
\hline 25 & strugalo na ravnoj strani / scraper on interior surface & 5 & $5.7 \%$ \\
\hline 28 & strugalo s obostranom obradbom / scraper with bifacial retouch & 1 & $1.1 \%$ \\
\hline 29 & izmjenično strugalo / alternate scraper & 4 & $4.6 \%$ \\
\hline 30 & grebalo / endscraper & 2 & $2.3 \%$ \\
\hline 32 & dubilo / burin & 2 & $2.3 \%$ \\
\hline 34 & svrdlo / borer & 2 & $2.3 \%$ \\
\hline 35 & svrdlenica / atypical borer & 2 & $2.3 \%$ \\
\hline 36 & nož hrptenjak / backed knife & 1 & $1.1 \%$ \\
\hline 37 & hrbasti nož / atypical backed knife & 1 & $1.1 \%$ \\
\hline 38 & prirodni nož hrptenjak / naturally-backed knife & 1 & $1.1 \%$ \\
\hline 39 & strugalica / raclette & 1 & $1.1 \%$ \\
\hline 40 & zarubak / truncation & 2 & $2.3 \%$ \\
\hline 42 & udubak / notch & 6 & $6.9 \%$ \\
\hline 43 & nazubak / denticulate & 5 & $5.7 \%$ \\
\hline 62 & razno / miscellaneous & 3 & $3.4 \%$ \\
\hline $64^{*}$ & komad s obradbom / retouched piece & 6 & $6.9 \%$ \\
\hline $65^{*}$ & ulomak oruđa / tool fragment & 6 & $6.9 \%$ \\
\hline \multicolumn{2}{|r|}{ Ukupno / Total } & 87 & $100.0 \%$ \\
\hline
\end{tabular}

Tab. 3 Tipološki sastav špilje Veternice. *Tipovi 64 (komadi s obradbom) i 65 (ulomci oruđa) nisu dio osnovne Bordesove tipologije, već su dodani za potrebe ove analize (izradio: M. Banda, 2019.)

Tab. 3 Typological composition of Veternica Cave. *Types 64 (retouched pieces) and 65 (tool fragments) are not part of the basic Bordes typology, but were added for the purpose of this analysis (made: M. Banda, 2019)

\begin{tabular}{|c|c|c|}
\hline Grupirani tipovi / Grouped types & $\mathrm{N}$ & $\%$ \\
\hline 1. tehnološki definirani tipovi / technologically defined types & 1 & $1,1 \%$ \\
\hline 2. šiljci / points & 4 & $4,6 \%$ \\
\hline 3. strugala / scrapers & 43 & $49,4 \%$ \\
\hline 4. gornjopaleolitički tipovi / Upper Paleolithic types & 13 & $14,9 \%$ \\
\hline 5. udupci i nazupci / notched and denticulated types & 11 & $12,6 \%$ \\
\hline 6. komadi s obradbom / retouched pieces & 6 & $6,9 \%$ \\
\hline 7. razno / miscellaneous & 3 & $3,4 \%$ \\
\hline 8. ulomci oruđa / tool fragments & 6 & $6,9 \%$ \\
\hline Ukupno / Total & 87 & $100,0 \%$ \\
\hline
\end{tabular}

Tab. 4 Grupirani tipovi oruđa špilje Veternice (izradio: M. Banda, 2019.)

Tab. 4 Grouped tool types of Veternica Cave (made by: M. Banda, 2019)

nih sirovina. lako je sirovinska analiza za kamene izrađevine preliminarna, važno je naglasiti kako se udio kvarcnih nalaza u sveukupnome skupu gotovo savršeno poklapa s podacima koje za udio kvarca (47\%) u Veternici navode Blaser et al. (2002: 395). Udio sirovina prema težini ponešto se razlikuje od odnosa količine. Naime, u slučaju težine kategorije kvarca i rožnjaka nešto su slabije zastupljene, ali ipak i dalje fragments, and miscellaneous types, are the same as in the detailed division of types.

\subsection{Raw-material analysis}

Percentages of different categories of raw materials in the lithic assemblage were obtained by the raw material analysis (Tab. 5). The most numerous category of raw ma- 


\begin{tabular}{|c|c|c|c|c|}
\hline Sirovina / Raw material & $\mathrm{N}$ & $\%(\mathrm{~N})$ & težina / weight (g) & \% (težina / weight) \\
\hline rožnjak / chert & 159 & $27.9 \%$ & 2118.4 & $22.2 \%$ \\
\hline crni eruptiv / black eruptive & 34 & $6.0 \%$ & 747.1 & $7.8 \%$ \\
\hline tuf / tuff & 11 & $1.9 \%$ & 252.2 & $2.6 \%$ \\
\hline pješčenjak ili lapilni tuf / sandstone or lapilli tuff & 31 & $5.4 \%$ & 621.0 & $6.5 \%$ \\
\hline silicificirani materijal / silicified material & 36 & $6.3 \%$ & 629.7 & $6.6 \%$ \\
\hline kvarc / quartz & 264 & $46.4 \%$ & 4146.1 & $43.5 \%$ \\
\hline neodređeno / indeterminate & 34 & $6.0 \%$ & 1006.4 & $10.5 \%$ \\
\hline Ukupno/ Total & 569 & $100.0 \%$ & 9520.9 & $100.0 \%$ \\
\hline
\end{tabular}

Tab. 5 Zastupljenost kategorija sirovina po količini i težini (izradio: M. Banda, 2019.)

Tab. 5 Presence of raw material categories by amount and weight (made: M. Banda, 2019)

čine najveće kategorije sirovina. Udio težine svih ostalih sirovina malo je veći u odnosu na količinski udio.

Kategorizacijom vrste okorine na izrađevinama iz sirovinske skupine A zabilježeno je kako većina nalaza s okorinom ima tragove valutične okorine. Od 114 nalaza s okorinom iz skupine A, čak 99 komada ili 86,8\% ima valutičnu okorinu, dok se za samo 7 primjeraka ili $6,1 \%$ moglo utvrditi da imaju nodularnu okorinu, a ostatku nalaza nije se mogla utvrditi vrsta okorine (7\%). U slučaju sirovinske skupine B, na čak 94 od 98 nalaza s okorinom prepoznata je valutična okorina, odnosno $95,9 \%$.

\section{INTERPRETACIJA I USPOREDBA}

\subsection{Interpretacija rezultata}

Jedan od najvećih problema u litičkoj analizi materijala iz špilje Veternice predstavlja pomiješanost nalaza, odnosno izgubljeni podaci o stratigrafskoj pripadnosti većine litičkoga skupa. Zbog toga je teško procijeniti koliko rezultati sadašnje analize stvarno predstavljaju sastav litičkih skupova pojedinih srednjopaleolitičkih slojeva. Kada se u obzir uzme i okolnost da je između nastanka slojeva koji su sadržavali mustjerske izrađevine vremenska razlika mogla biti i do nekoliko desetaka tisuća godina (Miracle, Brajković 2010: 220), problematika revizije nalaza iz Veternice postaje još složenija. Sa sličnom problematikom susreo se Simek (1991: 60-61; Simek, Smith 1997: 561) pri analizi kamenih izrađevina iz Krapine, koji je zbog toga litičke nalaze analizirao kao cjelinu. $U$ analizi izrađevina iz Veternice, svi kameni nalazi tretirani su kao dio istoga skupa, a ako postoji značajna razlika u proizvodnim postupcima, udjelu tipova oruđa ili sastavu sirovina između slojeva, nije ju moguće razjasniti zbog toga što crteži i fotografije izrađevina sa stratigrafskim podacima sadržavaju samo mali dio ukupnoga skupa koji se nalazi u Zavodu za paleontologiju i geologiju kvartara HAZU-a. Okolnost koja je dodatno otežala analizu je i nedostatak dijela izrađevina koji je primijećen tijekom usporednoga pregleda dostupnoga materijala i ilustracija iz Malezovih (1958; 1958/59; 1979a; 1981) i drugih (Radovčić, Škoberne 1989) radova. lako nije poznato nedostaje li još nalaza izuzev onih prikazanih u navedenim radovima, može se pretpostaviti kako njihov broj nije dovoljno značajan (najmanje 14 primjeraka) da utječe vidljivo na rezultate tehnološke analize. S druge strane, nalazi koji nedostaju većinom pripa- terial encompasses artefacts made from quartz, at $46.4 \%$ with 264 determined pieces. This is followed by different varieties of chert at $27.9 \%$. The categories of black eruptive, sandstone/lapilli tuff and silicified material are similarly represented, with percentages ranging between 5.4 and $6.3 \%$. The portion of tuffs is only $1.9 \%$, while artefacts of indeterminate raw materials make up $6 \%$. As most of the finds have no stratigraphical information, it is impossible to determine how much the Middle Paleolithic layers of Veternica differ in terms of raw material composition. Even though this raw material analysis for stone artefacts is preliminary, it is important to emphasize that the percentage of quartz artefacts in the entire assemblage corresponds almost perfectly with the data about the quartz percentage (47\%) in Veternica according to Blaser et al. (2002: 395). The percentage of raw materials by weight is somewhat different than by quantity. In terms of weight categories, quartz and chert are less represented, but still make up two of the largest categories of raw materials. The weight percentage of the remaining raw materials is a little larger than the quantitative percentage.

The categorization of cortex type for artefacts from raw material group $\mathrm{A}$ has determined that most of the finds with cortex have remnants of cobble cortex. Out of 114 finds with cortex from group A, 99 pieces or $86.6 \%$ have cobble cortex, while nodular cortex was determined for only 7 pieces or $6.1 \%$, and the type of cortex could not be determined for the remainder of the finds (7\%). In the case of raw material group B, 94 of 98 finds with cortex, or $95.9 \%$, have cobble cortex.

\section{INTERPRETATION AND COMPARISON}

\subsection{Interpretation of results}

One of the largest problems in the lithic analysis of the material from Veternica Cave is the mixing of the finds, or more precisely, the absence of data on the stratigraphic provenience of most of the lithic assemblage. Because of that, it is difficult to estimate in what measure the current analysis results actually represent the composition of the different Middle Paleolithic layers in the lithic assemblage. Considering that there could have been a temporal difference of tens of thousands of years between the formation of the layers which contained the Mousterian artefacts 
daju kamenom oruđu pa nije nerazumno pretpostaviti da je njihov nedostatak u određenoj mjeri utjecao na rezultate tipološke analize. Moguće je i da su sa srednjopaleolitičkim nalazima pomiješani i oni iz slojeva D i F (Miracle, Brajković 1992: 2). Ti nalazi bili su nedijagnostički (Miracle, Brajković 1992: 2), a pripisivanje sloja F orinjasijenu napravljeno je na temelju stratigrafskoga položaja sloja, a ne na temelju tipičnoga oruđa (Malez 1979a: 269; 1981: 81). Štoviše, pregledom materijala nije primijećena nijedna izrađevina koja bi upućivala na orinjasijen, odnosno orinjačku industriju, ili pak na gornji paleolitik općenito. Stoga, determinaciju orinjasijena u Veternici treba odbaciti.

Nadalje, još jedan aspekt koji utječe na sastav litičkoga skupa je i metodologija iskopavanja primijenjena u istraživanjima Mirka Maleza (Miracle et al. 2010: 140). Naime, iako Malez (1957: 280) navodi da je istraživanje Veternice teklo „...vrlo sporo, jer je potrebno biti na oprezu, da se pojedini nalazi ne razbiju i unište.", na fotografijama terenskih istraživanja (Malez 1956b: tab. I, sl. 1) vidljivo je kako se tijekom iskopavanja koristilo krupnim alatom, što odudara od suvremene metodologije istraživanja paleolitičkih nalazišta. Uz to, sedimenti iz špilje nisu prosijavani (Miracle et al. 2010: 140). O razlici u metodologiji iskopavanja u odnosu na današnju praksu svjedoči i brzina istraživanja, jer je tijekom pet istraživačkih sezona istražena površina od oko $207 \mathrm{~m}^{2}$, pri čemu je debljina sedimenata na pojedinim dijelovima nalazišta iznosila i do 8 m (Miracle, Brajković 1992: 2). Zbog primjene takvoga načina iskopavanja za očekivati je da je određena količina sitnih kamenih artefakata slučajno izostavljena, iako se među pohranjenim materijalom iz Veternice nalazi nekoliko takvih primjeraka. Stoga je moguće da su u određenoj mjeri podzastupljene kategorije poput odbojčića, ulomaka odbojaka, otkrhaka ili odbojaka od dodatne obradbe.

Analizom litičkoga materijala iz Veternice nastojalo se rekonstruirati dijelove proizvodnih postupaka, izradu i sastav oruđa, strategije prikupljanja sirovina, a u konačnici i interpretirati karakter nalazišta te njegovu litičku industriju smjestiti u kronološki i kulturni slijed s ostalim srednjopaleolitičkim nalazištima sjeverne Hrvatske.

Analiza sirovina pokazala je kako je najzastupljeniji materijal kvarc s udjelom od $46 \%$, a potvrda za njegov udio može se pronaći i u Blaser et al. (2002: 395). Iza kvarca najbrojnija kategorija sirovine jest rožnjak s oko $28 \%$. Već je navedena problematika određivanja sirovina na temelju makroskopskih obilježja, zbog čega se i ova analiza mora smatrati samo preliminarnom. Naime, u literaturi se navodi moguća greška od 5\% pri određivanju čak i s napravljenim izbruscima sirovine te uz pomoć mikroskopskoga promatranja obilježja (Zupanič 1970: 131). Međutim, još je jedan problem koji se mora navesti za rezultate ovoga dijela analize. Dobiveni udjeli pojedinih sirovina ne odražavaju dobro sve varijetete sirovina koje su zajedno grupirane. Ovo osobito vrijedi za kategorije rožnjaka i silicificiranih materijala koje obuhvaćaju varijetete sirovina koji se makroskopski jasno razlikuju, ali koji su zajedno svrstani zbog sličnih fizikalnih i kemijskih svojstava sirovine. Određeni varijeteti u pojedinim kategorijama sirovina javljaju se isključivo u jednom ili
(Miracle, Brajković 2010: 220), the issue of revising the finds from Veternica becomes even more complex. Simek (1991: 60-61; Simek, Smith 1997: 561) was faced with a similar issue when analysing stone artefacts from Krapina and for this reason treated the lithic finds as a whole. In the analysis of the artefacts from Veternica, all the stone finds were treated as part of the same assemblage; if there is a significant difference in production techniques and the composition of tool types or raw materials between layers, it is not possible to clarify it because the illustrations and photographs of the artefacts with stratigraphic data contain only a small portion of the entire assemblage that is housed in the Institute for Quaternary Paleontology and Geology of the Croatian Academy of Sciences and Arts. The analysis was made even more difficult by the absence of a portion of the artefacts, which was noticed after the examination of the available finds and illustrations from Malez's (1958; 1958/1959; 1979a; 1981) and other (Radovčić, Škoberne 1989) works. Although it is unknown whether there are any other missing artefacts besides the ones depicted in those works, it can be assumed that their number is not significant enough (at least 14 artefacts) to evidently influence the results of the technological analysis. On the other hand, the missing finds are predominantly stone tools, so it is not unreasonable to assume that their absence, in a certain manner, influenced the results of the typological analysis. It is also possible that the artefacts from layers D and F are mixed with Middle Paleolithic finds (Miracle, Brajković 1992: 2). These finds were non-diagnostic (Miracle, Brajković 1992: 2), and the attribution of layer $F$ to the Aurignacian was done on the basis of the stratigraphic position of the layer, not on the presence of typical tools (Malez 1979a: 269; 1981: 81). Moreover, during the examination of the material, no artefact indicated the presence of the Aurignacian or Upper Paleolihic in general. Therefore, the determination of the Aurignacian in Veternica must be discarded.

Another aspect influencing the lithic assemblage is the methodology applied in the excavations of Mirko Malez (Miracle et al. 2010: 140). Even though Malez (1957: 280) mentions that the excavation of Veternica proceeded "... very slowly, because it is necessary to be cautious, so that certain finds are not broken and destroyed", photographs of the excavation (Malez 1956b: Tab. I, Fig. 1) show that large tools were used for digging, which differs from the contemporary methodology of excavation of Paleolithic sites. Moreover, sediments from the cave were not sieved (Miracle et al. 2010: 140). The speed of excavation also testifies to a different excavation methodology when compared to contemporary practice, because a surface of about $207 \mathrm{~m}^{2}$ was excavated during five research seasons, with the thickness of the sediments reaching 8 metres in some places (Miracle, Brajković 1992: 2). With such a mode of excavation, it can be expected that a certain amount of small stone artefacts were incidentally omitted, even though there are such pieces among the stored material from Veternica. Therefore, it is possible that, to a certain extent, some categories such as small flakes, flake fragments, small chunks, or retouch flakes are under-represented. 
nekoliko primjeraka, ponajprije u obliku odbojaka i oruđa na njima. Najhomogenija sirovinska kategorija, barem prema makroskopskim obilježjima, jest skupina crnih eruptiva porfirne strukture. lako je kvarc relativno jednostavno odvojiti od ostalih sirovina na temelju njegovih karakteristika, i u toj je kategoriji primijećeno nekoliko varijeteta, što znači da su prikupljeni kvarcni obluci možda sekundarno deponirani iz različitih primarnih ležišta. Kategorizacijom okorine koja je prisutna na nalazima utvrđeno je da $86,8 \%$ svih komada s okorinom iz skupine A ima valutičnu okorinu, dok taj postotak za sirovinsku skupinu B raste na čak 95,9\%. Iz toga je jasno da je većina sirovine na nalazište donesena u obliku oblutaka, dok je jedan neusporedivo manji dio mogao biti prikupljen u drugačijim prirodnim oblicima. Obluci su mogli biti prikupljani u različitim vodotocima Medvednice, u aluvijalnim nanosima rijeke Save ili od pliocenskih konglomerata koji se prostiru južno od špilje i u sebi imaju uklopljene valutice raznih sirovina koje su erozijom ispadale iz stijene (Malez 1958/1959: 176; 1967: 269). Prema tome, sirovina prisutna u Veternici uglavnom je lokalnoga podrijetla, iako nije isključena mogućnost da su na lokalitet donesene i egzotične sirovine, kao što je već navedeno, u obliku gotovih oruđa. Budući da za Veternicu nisu utvrđeni točni izvori korišteni za prikupljanje sirovina, zasad se ne može reći koliku je ulogu igrala selekcija u strategiji prikupljanja. Ono što se može reći jest da visoki udio kvarca ne predstavlja nužno prikupljanje te sirovine zbog nedostupnosti kvalitetnijih materijala (de Lombera-Hermida, Rodríguez-Rellán 2016: 2-3; Driscoll 2010: 1; za suprotno mišljenje vidjeti: Mihailović 2014: 69), što se da zaključiti iz relativno uniformnoga načina proizvodnje kvarcnih izrađevina, prisutnosti pomno izrađenih oruđa od kvarca te nedostatka pojedinih dijelova lanca operacija što pak sugerira da su i kvarcne izrađevine bile uključene u strategije planiranja ili predviđanja budućih zadataka.

Litički skup Veternice je za potrebe tehnološke analize podijeljen na dvije sirovinske skupine, A i B, pa je shodno tome i analiza lanca operacija pratila takvu podjelu. $U$ sirovinskoj skupini A najčešće proizvodne kategorije su odbojci i ulomci odbojaka. Iza toga slijede kategorije krhotina s okorinom i otkrhaka, a potom i drugotni odbojci. Zajednički udio različitih kategorija neobrađenih odbojaka (prvotni odbojak, drugotni odbojak, nož s prirodnim hrptom, odbojak, dotjerujući odbojak jezgre) od 22,6\% i prisutnost jezgara svjedoči da se proizvodnja odbojaka u određenoj mjeri događala na nalazištu. Relativno dobro zastupljeni drugotni odbojci (8,2\%) ukazuju na to da su se na nalazištu događale i rane faze proizvodnje, odnosno redukcije jezgara. Međutim, prvotni odbojci su u lancu operacija slabo zastupljeni $(2,3 \%)$, što je vjerojatno rezultat djelomičnoga razokorivanja izvan nalazišta. Razokorivanje izvan nalazišta nije imalo za cilj potpuno skidanje okorine jer se drugotni odbojci javljaju u značajnoj mjeri, a jezgre u sedam od osam primjeraka na svojoj površini sadrže okorinu izvornoga komada sirovine. Dobro zastupljene kategorije krhotina sa i bez okorine $(9,1 \%)$ mogle bi također upućivati na proizvodnju artefakata na nalazištu, odnosno na slučajne lomove koji nastaju tijekom proizvodnje, ali nisu sasvim siguran pokazatelj jer mo-
The analysis of the lithic material from Veternica was conducted in order to reconstruct parts of the manufacturing techniques, production and composition of tools, raw material procurement strategies, and finally to interpret the character of the site and place its lithic industry in a chronological and cultural sequence with other Middle Paleolithic sites in northwestern Croatia.

The raw material analysis showed that the most abundant material was quartz at $46 \%$; the confirmation for this portion can be found in Blaser et al. (2002: 395). After quartz, the most numerous raw material category is chert at $28 \%$. We already mentioned the issue of determining raw material on the basis of macroscopic characteristics, which is why this analysis must be considered preliminary. In fact, the literature mentions a possible determination error of $5 \%$ even when thin sections are made and the characteristics are examined under the microscope (Zupanič 1970: 131). Furthermore, we should address another problem with the results of this part of the analysis. The obtained portions for different raw materials do not reflect well all the varieties of raw materials which are grouped together. This is especially true for the categories of cherts and silicified materials, which include varieties of raw materials that are macroscopically easily discernible, but are grouped together because they have similar physical and chemical properties. Certain varieties in particular raw material categories are present in only one or a couple of pieces, primarily in the form of flakes and tools made on them. The most homogeneous raw material category, at least considering its macroscopic properties, is the group of black eruptives of porphyric structure. Although quartz is relatively easy to discern from other raw materials on the basis of its characteristics, several varieties were also identified in that category, which means that the procured quartz cobbles may have been secondarily deposited from different primary deposits. It was determined that pieces with cobble cortex in the percentage of all the pieces with cortex amounted to $86.8 \%$ in raw material group $A$ and $95.6 \%$ in raw material group B. It is thus clear that most raw materials were brought to the site in the form of cobbles, while an incomparably smaller part could have been collected in different natural forms. Cobbles could have been procured from different streams of Medvednica, from the alluvial deposits of the river Sava, or from Pliocene conglomerates which extend south from the cave and have embedded cobbles of various raw materials that fell out of the parent rock by erosion (Malez 1958/1959: 176; 1967: 269). Thus, the raw materials present in Veternica are probably of local origin, though the possibility that exotic raw materials were brought on the site, primarily in the form of finished tools, is not excluded. Since exact raw material sources used for the procurement have not been determined, it is not possible to say how much of a role selection played in procurement strategies. But it can be concluded that the high portion of quartz does not represent a necessary procurement in the absence of better-quality materials (de Lombera-Hermida, Rodríguez-Rellán 2016: 2-3; Driscoll 2010: 1; for an opposite opinion see: Mihailović 2014: 69), which can be inferred from the relatively uniform production of quartz artefacts, 
gu nastati i prirodnim putem. Oruđa su se također proizvodila na nalazištu, što se može zaključiti iz toga da su često napravljena na istim sirovinama kao neobrađeni odbojci i jezgre. S druge strane, čini se da nisu sva oruđa rezultat in situ proizvodnje jer se pojedine izrađevine javljaju kao jedini primjerci određenih varijeteta sirovina.

Jezgre sirovinske skupine A relativno su slabo zastupljene $(2,6 \%)$, različitih su veličina i javljaju se na različitim sirovinama. Najzastupljenije su jezgre na kojima se vide tragovi centripetalnoga lomljenja, a uz njih se javljaju i jezgre s nepravilnim višesmjernim lomljenjem te jedna s nasuprotnim lomljenjem duguljastih odbojaka. Svi primjerci jezgara s višesmjernim nepravilnim lomljenjem iskorišteni su djelomično ili pak samo površno, a od njihovih sirovina zabilježeno je tek nekoliko odbojaka. Nasuprot tome, centripetalne jezgre su u većini slučajeva potpuno iskorištene, a samo se jedan primjerak može smatrati djelomično iskorištenim. Jezgra s nasuprotnim lomljenjem djelomično je iskorištena, iako je od njezine sirovine pronađeno više odbojaka.

Kada se podacima o jezgrama dodaju odnosi obrazaca tragova lomljenja na dorzalnoj strani odbojaka, potvrđuje se prevlast centripetalnoga lomljenja pri proizvodnji odbojaka jer radijalan/subradijalan obrazac tragova ima čak $35,8 \%$ svih analiziranih odbojaka. Međutim, i jednosmjerni i dvosmjerni-okomiti uzorci na odbojcima ipak imaju udio od $26,4 \%$, a takvi uzorci nisu vidljivi na prisutnim jezgrama. lako se navedena jezgra s nasuprotnim lomljenjem (T. 6: 7) može povezati s jednosmjernim uzorkom jer na većini svojih strana lomljenja ima istosmjerne tragove odbojaka, njezin udio u broju svih jezgara skupine $A$ ne može odgovarati udjelu jednosmjernoga uzorka na odbojcima. To dodatno potvrđuje činjenica da većina odbojaka s jednosmjernim uzorkom nije napravljena od jednake sirovine kao što je navedena jezgra. Za takvu okolnost postoje dva moguća objašnjenja. Jedno objašnjenje je da su neandertalske zajednice koje su proizvele jezgre odnijele neke on njih sa samoga nalazišta, pri čemu su slučajno ili namjerno odnešene i jezgre s jednosmjernim lomljenjem pa je njihov udio u litičkome skupu danas podzastupljen. Ovo objašnjenje nalazi potvrdu u prisutnosti više odbojaka iz rane faze proizvodnje, odnosno drugotnih odbojaka velikih dimenzija napravljenih od istih sirovina od kojih pak nije zabilježena nijedna jezgra. Drugo objašnjenje je da je jednosmjerno lomljenje prethodilo centripetalnome $u$ istome proizvodnom postupku. Takav postupak sličan je onome koji je predložio Baumler (1987: 166-168; 1988: 271) za mustjersko nalazište u Zobištu (Bosna i Hercegovina). Naime, u takvom postupku jezgra je prvo reducirana jednosmjernim lomljenjem, nakon čega je u završnoj fazi proizvodnje ista jezgra centripetalno lomljena, vjerojatno kako bi se nakon njezina smanjivanja maksimalno iskoristio volumen jezgre za dobivanje prikladnih odbojaka (Baumler 1988: 271). Čini se da u Veternici to potvrđuje prisutnost oba obrasca lomljenja na odbojcima od iste sirovine, iako u litičkome skupu nedostaju velike jednosmjerne jezgre koje bi ukazivale na ranu fazu proizvodnje kao što je to slučaj u Zobištu (Baumler 1988: 261). Odbojci s dvosmjernim-okomitim uzorkom možda u tome slučaju predstavljaju prijelaz između dva navedena načina reduk- the presence of finely made quartz tools, and the absence of particular parts of the chaîne opératoire, which suggests that quartz artefacts were included into the planning strategies or the anticipation of future tasks.

For the purpose of the technological analysis, the lithic assemblage of Veternica was divided into two raw material groups, A and B. Accordingly, the analysis of the chaîne opératoire followed the same division. The most common production categories in raw material group A are flakes and flake fragments. These are followed by chunks with cortex, small chunks, and secondary decortication flakes. A common portion of different unretouched categories (primary decortication flake, secondary decortication flake, naturally-backed knife, flake, retouch core flake) of $22.6 \%$ and the presence of cores suggest that the production of flakes occurred to a certain extent on the site itself. The relatively well represented secondary decortication flakes (8.2\%) suggest that the early stages of production or core reduction likewise happened on the site. However, primary decortication flakes are poorly represented in the chaîne opératoire $(2.3 \%)$, which is probably a result of partial decortications outside the site. The decortication outside the site was probably not aimed at the complete removal of the cortex because secondary flakes occur in a significant amount, and the surface of cores in seven out of eight pieces has cortex from the original piece of raw material. The well-represented categories of chunks with and without cortex (9.1\%) could testify to the production of artefacts on-site, or more precisely, to the haphazard fractures that occur during production, but are not a definite indicator because they can happen due to natural processes. The tools were also produced on-site, which can be inferred from the fact that they were made from the same raw materials as the unretouched flakes and cores. On the other hand, it seems that not all the tools are the result of in situ manufacturing, because some artefacts are the only examples of a variety of a given raw material.

The cores of raw material group A, relatively poorly represented (2.6\%), are of different sizes and made of various raw materials. The most common ones are cores with centripetal reduction, but there are also cores with irregular multidirectional reduction, and one with opposite reduction of long flakes. All core examples with irregular multidirectional reduction are only partially or superficially exploited; only a few flakes from their raw material have been noted. In contrast, centripetal cores are in most cases completely exhausted, and only one piece can be considered partially exploited. The single core with opposite reduction is partially exhausted, although multiple flakes of the same raw material have been found.

When the ratios of scar patterns on the dorsal sides of flakes are added to the data about cores, the prevalence of centripetal reduction is confirmed, because $35.8 \%$ of all analysed flakes have a radial/subradial pattern. However, unidirectional and bidirectional-perpendicular patterns on flakes still account for $26.4 \%$, and these patterns are not visible on the present cores. Even though the aforementioned core with opposite reduction (PI. 6: 7) can be linked to the 
cije jezgre ili pak na svojoj dorzalnoj strani sadrže samo dio površine nekadašnje strane centripetalne jezgre pa zapravo nemaju sačuvane sve tragove strane jezgre od koje su i odlomljeni (Baumler 1988: 266, 271). U Veternici nisu pronađeni dokazi za prisutnost levaloaškoga postupka, iako nekoliko izrađevina podsjeća na levaloaške odbojke (T. 1: 3; 4: 2). Jedan nalaz vrlo je sličan levaloaškom šiljku (T. 6: 6), ali je napravljen od iste sirovine kao i već navedena nasuprotna jezgra (T. 6: 7). Böeda (1995: 45) je pokazao da levaloaški šiljci mogu nastati iz različitih proizvodnih postupaka, pa prisutnost ovoga primjerka u Veternici ne znači nužno i prisutnost levaloaškoga proizvodnog postupka. Među odbojcima se javlja i nekoliko primjeraka levaloaških pašiljaka (T. 3: 7; 6: 10) koji obično nastaju centripetalnim lomljenjem (Debénath, Dibble 1994: 52; Karavanić et al. 2015: 107).

Od plohaka u sirovinskoj skupini A najbrojniji su glatki (33,2\%), višeplošni $(21,6 \%)$ i okorinski oblici $(16,3 \%)$. Budući da glatki i okorinski plošci zajedno čine oko polovice svih analiziranih plohaka unutar te skupine, može se pretpostaviti da proizvodni postupak u većini slučajeva nije bio popraćen pripremom udarne plohe jezgre, već je kao udarna ploha korištena okorinska površina sirovine ili pak prijašnji trag odbojka. Međutim, višeplošni plošci čine petinu svih zabilježenih plohaka te svjedoče da se priprema udarne plohe ipak u određenim slučajevima provodila tijekom proizvodnoga postupka.

U lancu operacija sirovinske skupine B najbrojnije proizvodne kategorije su ulomci odbojaka $(34,1 \%)$ i odbojci (16,3\%). Relativno visoki udio neobrađenih odbojaka s okorinom (8\%) i neobrađenih odbojaka bez okorine (14\%) te prisutnost jezgara $(3,5 \%)$ govori u prilog tome da je u slučaju kvarca većina proizvodnje bila provođena na samome nalazištu. $U$ istoj skupini zanimljiv je i visoki udio krhotina. Krhotine bi mogle neizravno upućivati na proizvodnju kamenih izrađevina, pogotovo kada se radi o kvarcu koji je sklon nepravilnome pucanju. $S$ druge strane, moguće je da je visok udio krhotina sa i bez okorine $(19,7 \%)$ u skupovima kvarcnih izrađevina djelomično posljedica neuspješnoga prepoznavanja distalnih i medijalnih ulomaka odbojaka, što je eksperimentom pokazao Driscoll (2010: 315). Valja naglasiti da se u odnosu na skupinu A odbojčići javljaju u značajnijoj mjeri (9,5\% naprema 3,9\% u skupini A) te, iako nema nijednoga obrađenog primjerka, možda ukazuje na namjernu proizvodnju manjih izrađevina kako bi se izbjegli slučajni lomovi koji su česti kod redukcije kvarca, napose pri izradi većih odbojaka.

Jezgre pružaju najbolji uvid u proizvodne postupke primijenjene na kvarcnoj sirovini. Naime, od devet jezgara u sirovinskoj skupini $B$, sa šest primjeraka najbrojnije su klinaste (eng. cobble wedge) jezgre. Takve jezgre klinastoga su oblika, napravljene isključivo od oblutaka, a udarna ploha im je okorinska i od nje se oblik jezgre sužava prema suprotnoj strani (sl. 6). Često na sebi imaju tragove lomljenja na više strana koji idu ukrug oko okorinske plohe pa im se obrazac lomljenja u smislu orijentacije može smatrati prijelaznim između centripetalnog i jednosmjernog oblika. Ovakav način redukcije jezgre predstavlja prilagodbu zbog korištenja sirovina u obliku oblutaka. Osim klinastih jezgara, koje do- unidirectional patterns because it has unidirectional scars on most of its knapping faces, its share in the total number of cores cannot correspond to the number of unidirectional pattern on flakes. This is further confirmed by the fact that most flakes with unidirectional patterns are not made from the same raw material as the mentioned core. There are two explanations for this circumstance. One explanation is that the Neanderthal groups which produced the cores took some of them from the site itself, together with the unidirectional cores (which they took purposefully or incidentally), making their portion in the lithic assemblage under-represented today. This explanation is confirmed by the presence of a number of flakes from the early stages of reduction, or more precisely, the secondary decortication flakes of large dimensions made of the same raw material, of which, on the other hand, no cores were recognized. The second explanation is that the unidirectional reduction preceded the centripetal one in the same production technique. This mode of reduction is similar to the one proposed by Baumler (1987: 166-168; 1988: 271) for the Mousterian site of Zobište (Bosnia and Herzegovina). In this technique, the core was first reduced by unidirectional knapping, after which the same core was centripetally flaked in the final stage of manufacture, probably to maximally exploit its volume for producing adequate flakes after it became smaller in size (Baumler 1988: 271). The presence of both patterns of reduction on the flakes from the same raw material seems to suggest this mode of reduction, although there are no large unidirectional cores which would point to the early stage of manufacture as in Zobište (Baumler 1988: 261). In this case, the flakes with bidirectional-perpendicular patterns perhaps represent a transition between the two mentioned modes of reduction or even contain just a part of the core face on their dorsal side and thus do not preserve all the scars from the face from which they were flaked (Baumler 1988: 266, 271). In Veternica, there is no evidence for the Levallois method, even though several artefacts resemble Levallois flakes (PI. 1: 3; 4: 2). One find is very similar to a Levallois point (PI. 6: 6) but is made from the same raw material as the already mentioned core with opposite reduction (PI. 6: 7). Böeda (1995: 45) has shown that Levallois flakes can be manufactured with various methods so the presence of this example in Veternica does not necessarily entail the Levallois method. The flakes include several examples of atypical Levallois flakes (PI. 3: 7; 6: 10), which usually result from centripetal flaking (Debénath, Dibble 1994: 52; Karavanić et al. 2015: 107).

The most common flake platforms in raw material group A are flat (33.2\%), faceted (21.6\%), and cortical (16.3\%). Because flat and cortical platforms together constitute about half of all the analysed platforms in that group, it can be assumed that the reduction in most cases was not preceded by striking platform preparation, and the reduction was conducted by using the cortical surface of the raw material or a previous flake scar as a striking platform. However, faceted platforms make a fifth of all the noted platforms and suggest that striking platform preparation was nevertheless made in certain cases during the reduction. 


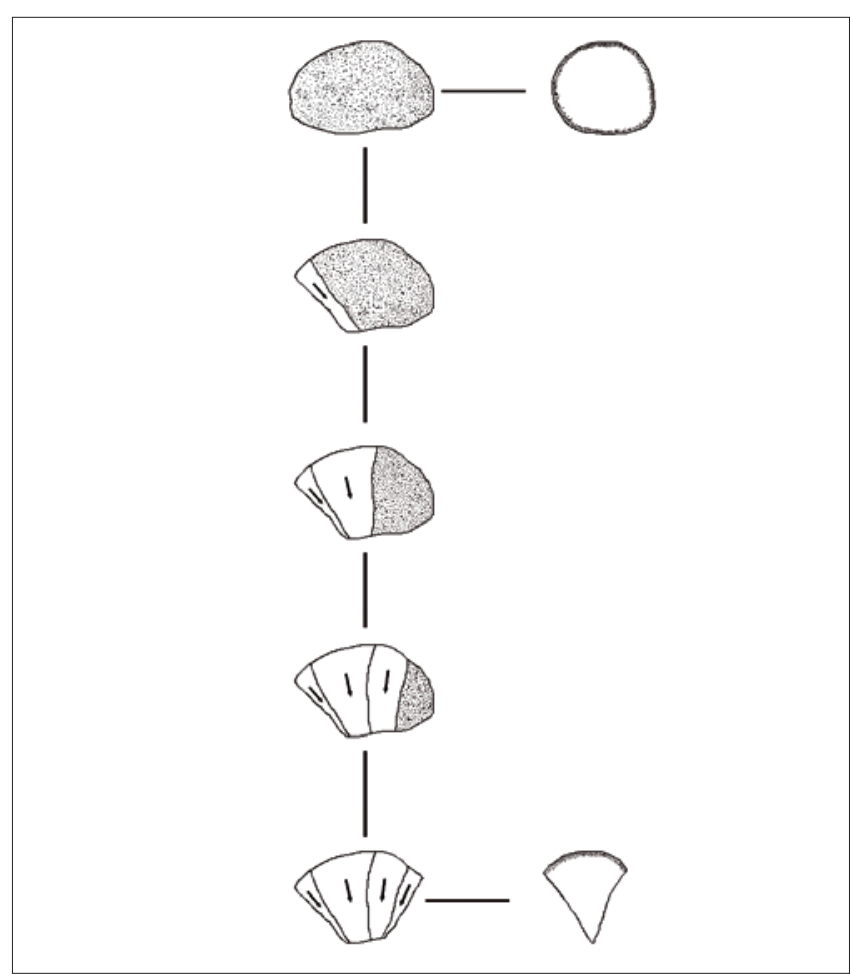

SI. 6 Shematski prikaz redukcije klinastih jezgara od nemodificiranoga oblutka do završne morfologije jezgre s presjecima početne i završne faze (izradio: M. Banda, 2019.)

Fig. 6 Schematic depiction of the cobble-wedge core reduction from the unmodified cobble to the final morphology of the core, with the cross-section of the initial and final phase (made by: M. Banda, 2019)

laze samo u sirovinskoj skupini B, javljaju se i dvije jezgre na odbojcima s malobrojnim tragovima iskorištavanja i jednosmjernom orijentacijom tragova, a kao udarna ploha služila je ventralna strana odbojka. Zanimljiv je i pronalazak jedne bipolarne jezgre, jedne od najmanjih jezgara u skupini $B, s$ jednim nedvojbenim tragom bipolarnoga lomljenja. Međutim, iako je primijećeno da odbojci ponekad imaju tragove oštećenja na distalnoj strani, nije se moglo sa sigurnošću izdvojiti nijedan bipolarni odbojak. Na temelju sastavljanja dva različita slijeda odbojaka utvrđeno je kako je proizvodni postupak lomljenja oblutaka mogao biti provođen i tako da se prvo jednim udarcem odlomio odbojak čiji je nastali trag na oblutku dalje služio kao glatka udarna ploha, od koje su sljedeći odbojci lomljeni ukrug. Taj se način vidno razlikuje od redukcije klinastih jezgara. Međutim, nisu zabilježene jezgre koje bi svjedočile o završnoj fazi takvoga postupka, ali to može biti i posljedica neprepoznavanja takvih oblika jezgara zbog poteškoća pri analiziranju tragova lomljenja na kvarcu.

Od plohaka sirovinske skupine B nabrojnije kategorije su glatki i okorinski oblici koji zajedno čine $81 \%$ svih analiziranih plohaka skupine B. S druge strane, zajednički udio dvopovršinskih i višeplošnih plohaka manji je od 5\%, što upućuje na to da je priprema udarne plohe jezgre prije lomljenja u slučaju kvarca bila iznimno rijetka. Ipak, valja naglasiti da su glatki plošci $(63,2 \%)$ višestruko brojniji nego okorinski
The most numerous categories in the chaîne opératoire of raw material group B are flake fragments (34.1\%) and flakes $(16.3 \%)$. The relatively high portion of unretouched flakes with cortex (8\%), unretouched flakes without cortex (14\%) and the presence of cores (3.5\%) suggests that, in the case of quartz, most of the production was conducted onsite. Interestingly, there is a high portion of chunks in this group. Chunks could indirectly point to stone artefact manufacture, especially in the case of quartz, which is prone to irregular fractures. On the other hand, it is possible that the high percentage of chunks with and without cortex $(19.7 \%)$ in quartz lithic assemblages is a consequence of unsuccessful recognition of distal and medial flake fragments, which was experimentally shown by Driscoll (2010: 315). It has to be emphasized that small flakes are significantly more present when compared to group A (9.5\% versus 3.9\% in group $A$ ), and even though there are no retouched pieces, this may point to a deliberate manufacture of smaller artefacts in order to avoid incidental fractures which are common when knapping quartz, especially during the manufacture of large flakes.

Cores provide the best insight into the manufacture methods applied to quartz raw materials. Of the nine cores in raw material group $B$, the most common are cobble wedge cores with six instances. Such cores are wedgeshaped, made exclusively from cobbles, the striking platform is cortical and the shape of the core narrows from it to the opposite side (Fig. 6). Generally, they have flake scars on multiple faces that extend around the cortical striking platform, which is why their pattern of flaking in regard to orientation can be considered transitional, between centripetal and unidirectional forms. This mode of reduction represents an adaptation to the use of raw materials in the form of cobbles. Aside from cobble wedge cores, which are found only in raw material group $B$, there are two cores on flakes with sparse flake scars and unidirectional orientation of scars where the ventral side of the original flake served as a striking platform. Also of interest is the identification of one bipolar core, one of the smallest cores in group B, with one unambiguous scar from bipolar flaking. However, even though flakes sometimes have traces of damage on the distal side, it was not possible to distinguish a bipolar flake with certainty. On the basis of refitting two different sequences of flakes, it was determined that the reduction of cobbles could have been conducted initially by knapping a flake with one strike. The resulting scar would further be used as a flat striking platform from which the ensuing flakes were knapped in a circle. This way is evidently different from the reduction of cobble wedge cores. However, no cores that would testify to the final stages of this reduction were noted, but this can be a consequence of not recognizing such core forms because of the difficulties in analysing flake scars on quartz.

The most numerous flake platforms in raw material group B are flat and cortical forms. Together, they make $81 \%$ of all the analysed platforms in group B. On the other hand, the common proportion of dihedral and faceted platforms is le- 
plošci $(17,8 \%)$, što upućuje na to da je lomljenje od glatke udarne plohe bilo češće nego što se to da naslutiti iz uzorka jezgara. Među kvarcnim izrađevinama zabilježena su i dva relativno velika odbojka kojima je odlomljen proksimalni dio ventralne strane, ali se ne može sa sigurnošću utvrditi radi li se o stanjivanju hrpta, slučajnom lomu pri redukciji ili o proizvodnom postupku Kombewa. Uz to se mora napomenuti da nije evidentiran nijedan odbojak s dvjema ventralnim stranama koji bi potvrdio prisutnost proizvodnoga postupka Kombewa.

Oruđa, odnosno obrađeni komadi u ukupnome litičkom skupu čine $15 \%$. Tipološka analiza pokazala je da su najzastupljenija jednostrana ravna $(11,5 \%)$ i jednostrana izbočena strugala $(9,2 \%)$, a da su relativno dobro zastupljeni i udupci $(6,9 \%)$, nazupci $(5,7 \%)$, komadi s obradbom $(6,9 \%)$, poprečna izbočena $(5,7 \%)$, izmjenična $(4,6 \%)$ i strugala na ravnoj strani $(5,7 \%)$. Zabilježeno je i nekoliko primjeraka mustjerskih šiljaka (4,6\%). lako se uz navedene tipove oruđa javljaju još brojne kategorije, njihov je udio relativno malen. Međutim, kada se oruđa grupiraju u šire grupe kako je to predloženo u Debénath, Dibble (1994), a učinjeno i u Karavanić et al. (2008) te Ahern et al. (2004), razlike između pojedinih skupina oruđa postaju naglašenije. Naime, strugala čine oko polovicu svih zabilježenih oruđa, iza njih slijede različiti gornjopaleolitički tipovi (grebalo, dubilo, svrdlo, svrdlenica, nož hrptenjak, hrbasti nož, strugalica) s oko $15 \%$, a potom i udupci i nazupci s oko $13 \%$. Ostale grupe oruđa znatno su manje zastupljene te zajedno imaju udio od oko $20 \%$. Nadalje, oruđa iz Veternice jako variraju u veličini, što je vjerojatno djelomično posljedica pomiješanosti nalaza jer Malez (1967: 270) navodi da su oruđa iz sloja H u prosjeku manja od onih iz slojeva I i J. Međutim, ilustrirani primjerci (Malez 1981: sl. 6-9) čine premali uzorak da bi se pouzdano izračunala prosječna veličina oruđa po slojevima. Također, iako su gornjopaleolitički tipovi relativno dobro zastupljeni, niti na jednome primjerku ne može se prema karakteristikama izradbe potvrditi potječe li iz nekih mlađih slojeva jer ti tipovi dolaze i u srednjem paleolitiku. Štoviše, nekoliko primjeraka izrađeno je od istih sirovina od kojih su napravljena i tipična mustjerska oruđa. Prema tome, ako su sa srednjopaleolitičkim skupom pomiješane izrađevine iz gornjopaleolitičkih slojeva, čini se da to nisu oruđa već druge proizvodne kategorije koje se ne mogu raspoznati.

Na temelju navedenih podataka može se ustanoviti kako je nastanjivanje špilje Veternice $u$ razdoblju srednjega paleolitika bilo popraćeno prikupljanjem kamenih sirovina, proizvodnjom i održavanjem (popravcima) kamenih oruđa, paljenjem vatre za zagrijavanje prostora ili obradu hrane te vjerojatno i drugim aktivnostima od kojih nisu ostali arheološki tragovi. Bez tafonomske analize nije moguće pouzdano reći ukazuju li prisutne životinjske kosti na plijen neandertalskih lovaca (Miracle 1991: 208). U slojevima sa srednjopaleolitičkim nalazima, $\mathrm{H}$, I i J, kosti špiljskoga medvjeda čine udio od $75 \%$ svih pronađenih ostataka faune (Malez 1963: 73-74). Miracle (1991: 215) smatra da su u slojevima u kojima prevladavaju ostaci mesoždera kosti drugih životinja vjerojatno dospjele kao rezultat aktivnosti tih mesoždera koji su špilju koristili kao brlog. Jednako tako, prisutnost ss than $5 \%$, indicating that the preparation of core striking platform before knapping was exceptionally rare. However, it should be emphasized that flat platforms (63.2\%) are many times more numerous than cortical platforms (17.8\%), suggesting that the reduction from flat striking platforms was more common than what was noticed in the sample of cores. Two relatively large flakes with a flaked proximal side of the ventral surface have been noted among quartz artefacts, but it cannot be determined with certainty whether it is a result of back thinning, incidental fracture during the reduction, or the Kombewa method. Here it must be mentioned that there were no flakes with two ventral sides that would indicate the Kombewa method.

Tools or retouched artefacts constitute $15 \%$ of the entire lithic assemblage. The typological analysis showed that the most common tools are straight (11.5\%) and convex sidescrapers $(9.2 \%)$, and that there is a relatively large share of notches $(6.9 \%)$, denticulates $(5.7 \%)$, retouched pieces $(6.9 \%)$, transverse convex scrapers (5.7\%), alternate scrapers (4.6\%), and scrapers on the interior side (5.7\%). Several examples of Mousterian points were also noted (4.6\%). Although there are more tool categories, their percentages are relatively small. However, when tools are included into wider groups as proposed in Debénath, Dibble (1994), and done in Karavanić et al. (2008) and Ahern et al. (2004), inter-group differences become more pronounced. In fact, scrapers make up about half of all the recognized tools, followed by various Upper Paleolithic types (endscraper, burin, borer, atypical borer, backed knife, atypical backed knife, raclette) at about $15 \%$, and by notches and denticulates at about $13 \%$. The remaining groups of tools are significantly smaller, amounting to about $20 \%$ altogether. Furthermore, tools from Veternica vary drastically in size, which is probably a consequence of mixing the finds, because Malez (1967: 270) notes that tools from layer $\mathrm{H}$ were on average smaller than those from layers I and J. However, the illustrated examples (Malez 1981: Figs. 6-9) do not constitute a large enough sample to dependably calculate the average tool size per layer. Likewise, although Upper Paleolithic types are well represented, none of the examples can be confirmed by its manufacture characteristics to come from some of the younger layers, and these types can be found in the Middle Paleolithic as well. Moreover, some examples were made from the same raw materials from which typical Mousterian tools were made. Because of that, if the artefacts from the Upper Paleolithic layers are indeed mixed with the Middle Paleolithic assemblage, it seems that these are not tools but other manufacturing categories which cannot be recognized as such.

The aforementioned data establishes that the occupation of Veternica Cave in the Middle Paleolithic period was accompanied with raw material procurement, manufacture and maintenance (repairs) of stone tools, lighting fires for warming spaces or food processing, and probably with other activities of which no archaeological traces survived. Without a taphonomic analysis, it is not possible to reliably say if the present animal bones indicate the prey of Neanderthal hunters (Miracle 1991: 208). In the layers with the Middle Paleolithic finds, $\mathrm{H}, \mathrm{I}$ and J, cave bear bones make up 
kostiju mesoždera nije posljedica ljudskoga lova, već smrti tijekom hibernacije ili zbog sukoba oko staništa među pripadnicima iste vrste (Miracle 1991: 205, 209-210). Zanimljivo je da u slojevima D, E i F, gdje su vrlo rijetki tragovi ljudskoga nastanjivanja, ostaci špiljskoga medvjeda čine 99\% svih životinjskih ostataka (Malez 1963: 74; Miracle, Brajković 1992: 2), dok u srednjopaleolitičkim slojevima koji imaju brojnije arheološke ostatke druge faunalne vrste imaju značajniji udio. Međutim, samo tafonomska analiza može sa sigurnošću pokazati je li ovaj obrazac posljedica ljudske lovne aktivnosti. Nadalje, lanac operacija kamenih izrađevina svjedoči da špilja Veternica u vrijeme srednjega paleolitika nije bila specijalizirano stanište samo za pojedine aktivnosti, već karakter nalaza (sastav sirovina, proizvodni postupci, sastav oruđa) govori o širem rasponu aktivnosti. Kao takvo, nalazište je opetovano nastanjivano u više navrata kroz dugi vremenski period. Međutim, ostaje otvoreno pitanje koliko su dugo mogle trajati pojedine faze naseljavanja, na što će u budućnosti teško biti odgovoriti jer su nalazi iz različitih slojeva pomiješani. Ipak, na temelju prevlasti medvjeđih kostiju može se zaključiti kako su tijekom interglacijala i ranog glacijala špilju kao stanište naizmjence koristili ljudi i medvjedi. Iz tlocrta koji donosi M. Malez (1981: sl. 2) čini se da većina litičkih nalaza potječe iz ulazne dvorane te nešto manje iz predšpiljskoga prostora (sl. 1). U ovim dijelovima također je pronađena i većina ostataka srednjopaleolitičkih vatrišta. Može se stoga pretpostaviti da je većina aktivnosti neandertalskih zajednica provođena u navedenim dijelovima špilje, vjerojatno zbog dostupnosti danjega svjetla. Zbog maloga prostora početnoga dijela špilje, za pretpostaviti je da su zajednice koje su tu obitavale imale mali broj pripadnika.

\subsection{Usporedba s istovremenim nalazištima}

Na prostoru jugoistočne i srednje Europe postoji nekoliko nalazišta koja su usporediva s Veternicom, sva uglavnom datirana u vrijeme posljednjega interglacijala i ranoga glacijala, odnosno u MIS 5 i 4. Geografski najbliže nalazište je Krapina, datirana na 130.000 godina prije sadašnjosti, odnosno u MIS 5e (Rink et al. 1995: 24). Kao i u Veternici, većina sirovine lokalnoga je podrijetla, a prikupljana je u obliku oblutaka (Zupanič 1970: 135). Za Krapinu je čak utvrđena i određena selekcija dostupne sirovine jer se rožnjak javlja u litičkome skupu u većem udjelu nego što je prisutan u obližnjem potoku Krapinici (Simek 1991: 67). Nadalje, tehnologija proizvodnje odbojaka pokazuje određene sličnosti s onom iz Veternice. Naime, glavni proizvodni postupak u Krapini sastojao se o redukcije oblutaka po okorinskoj plohi, čime su nastajale klinaste jezgre (Simek 1991: 66; Simek, Smith 1997: 561-562). Međutim, razlika između dva nalazišta je u tome što je u Krapini ovaj postupak korišten za razne sirovine, dok je u Veternici on isključivo korišten za proizvodnju kvarcnih izrađevina (sirovinska skupina B). S druge strane, u sirovinskoj skupini A iz Veternice glavni je proizvodni postupak centripetalna redukcija, a u Krapini su takve jezgre rijetke. Još jedna razlika između dva skupa je i to što u Krapini veliki udio jezgara čine jezgre na odbojcima. S druge strane, takve su jezgre u Veternici zastupljene samo u dva primjerka, oba napravljena od kvarca. Globularne i nepravil-
$75 \%$ of all the found faunal remains (Malez 1963: 73-74). Miracle (1991: 215) argues that the layers with a prevalence of carnivore remains include bones of other animals probably as a result of the activity of the carnivores that used the cave for denning. Equally, the presence of carnivore bones is not the result of human hunting activities, but of hibernation deaths or intra-species conflicts for shelter (Miracle 1991: 295, 209-210). It is interesting that cave bear remains make up $99 \%$ of all the faunal remains in layers D, E and F, in which traces of human settlement are very sparse (Malez 1963: 74; Miracle, Brajković 1992: 2), while other faunal species have a more significant portion in the Middle Paleolithic layers with more numerous archaeological remains. However, only a taphonomic analysis can show with certainty if this pattern is the consequence of human hunting activities. Furthermore, the chaîne opératoire of stone artefacts testifies that Veternica Cave in the Middle Paleolithic was not a specialized site for specific activities, since a wider scope of activities is suggested by the character of the finds (raw material composition, production techniques, tool composition). As such, the site was repeatedly occupied in numerous phases. However, how long individual phases of settlement lasted is still an open question, which will be difficult to resolve in the future because the finds from various layers are intermixed. But, on the basis of prevalence of bear bones it can be concluded that the site was interchangeably used by humans and bears during the interglacial and early glacial. The ground plan provided by M. Malez (1981: Fig. 2) indicates that most lithic finds come from the entrance chamber, while a smaller amount comes from the space in front of the cave (Fig. 1). Most Middle Paleolithic hearths were also found in these places. It can thus be assumed that most of the activities of Neanderthal groups were conducted in the mentioned parts of the cave, probably due to the availability of daylight. Because of the small space of the entrance area of the cave, it can be assumed that the groups occupying the site were small.

\subsection{Comparison with contemporary sites}

There are several sites in Southeast and Central Europe which are comparable to Veternica, all generally dated to the last interglacial and early glacial, or to the MIS 5 and 4. The geographically nearest site is Krapina, dated to 130.000 years BP or MIS 5e (Rink et al. 1995: 24). As in Veternica, most of the raw material is of local origin and procured in the form of cobbles (Zupanič 1970: 135). In Krapina, even a certain selection of available raw materials was identified, because chert is better represented in the lithic assemblage than in the nearby Krapinica stream (Simek 1991: 67). Furthermore, the technology of flake production shows certain similarities with Veternica. In fact, the main mode of production in Krapina consisted of a reduction of cobbles from a cortical striking surface, which produced cobble wedge cores (Simek 1991: 66; Simek, Smith 1997: 561-562). However, the difference between the two sites is that this technique was used on various raw materials in Krapina, while it was applied exclusively to the production of quartz artefacts in Veternica (raw material group B). On the other 
ne jezgre javljaju se na oba nalazišta, ali nemaju nikakvoga usporednog značaja. lako češći u starijim slojevima (Simek, Smith 1997: 572), levaloaški proizvodni postupak, kojega u Veternici uopće nema, u Krapini je rijedak, a određen je samo na temelju odbojaka (Simek 1991: 66). Tipološki sastav oba lokaliteta također je sličan (sl. 7). U Krapini su, osim strugala, udubaka i nazubaka, česti i prirodni noževi hrptenjaci (Simek 1991: 62; Simek, Smith 1997: 566), dok je udio u noževa u Veternici zanemariv. Razlika u udjelu prirodnih noževa hrptenjaka može biti odraz proizvodnih postupaka jer se u Veternici kod redukcije sirovina iz skupine A nisu proizvodile klinaste jezgre, već samo kod redukcije kvarca. Naime, zbog načina lomljenja oblutka ukrug pri proizvodnji klinastih jezgara često nastaju prirodni noževi hrptenjaci (Simek 1991: 66). Osim toga, u Krapini su gornjopaleolitički tipovi rijetko zastupljeni, dok u Veternici oni u grupiranoj tipologiji čine drugu najbrojniju kategoriju.
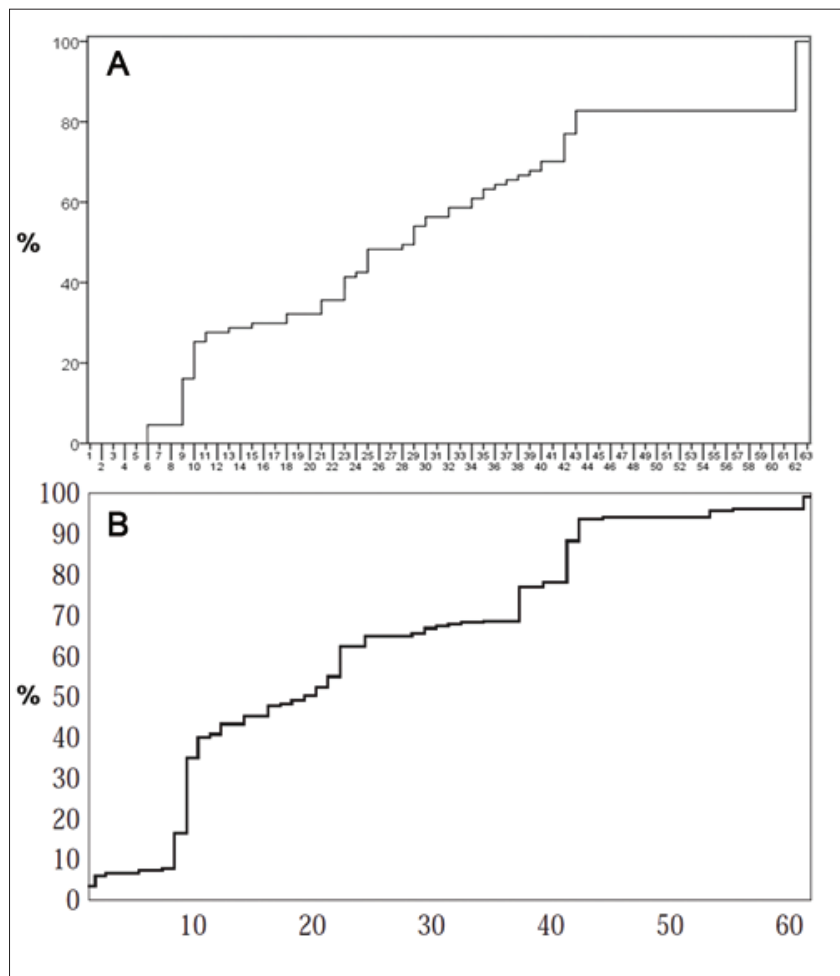

SI. 7 Kumulativne krivulje skupova oruđa Veternice (A) i Krapine (B) (A izradio: M. Banda, 2019.; B modificirano prema: Simek, Smith 1997, Fig. 3: doradio: M. Banda, 2019.). U kumulativnoj krivulji A pod tip 62 (ostalo) svrstani su također tipovi 64 (komadi s obradbom) i 65 (ulomci oruđa) zbog pogodnije vizualne usporedbe s kumulativnom krivuljom Krapine (B)

Fig. 7 Cumulative curvatures of tool assemblages of Veternica $(A)$ and Krapina (B) (A made by: M. Banda, 2019; B after: Simek, Smith 1997, Fig. 3: modified by: M. Banda, 2019). In the cumulative curvature, A types 64 (retouched piece) and 65 (tool fragments) were included into the type 62 (miscellaneous) for an adequate visual comparison with the cumulative curvature of Krapina (B)

Određene sličnosti litičkoga skupa nalaza iz Veternice mogu se primijetiti s litičkom industrijom Petrovaradinske tvrđave u Srbiji, koja se okvirno datira od početka MIS 3 do MIS 6 (Mihailović 2009: 129). Naime, uz korištenje rožnjaka na tome lokalitetu dobro su zastupljene i izrađevine od hand, the main mode of production in raw material group $A$ from Veternica was centripetal reduction, while such cores are rare in Krapina. Another difference is that a large part of the cores in Krapina were made of flakes. On the other hand, such cores are present in only two pieces in Veternica, both made from quartz. Globular and irregular cores are present on both sites, but do not have any comparative significance. Although more common in older layers (Simek, Smith 1997: 572), the Levallois method, not present in Veternica, is rare in Krapina, determined only from the flake sample (Simek 1991: 66). The typological composition of both sites is also similar (Fig. 7). Common pieces in Krapina include not only scrapers, notches and denticulates, but also naturallybacked knives (Simek 1991: 62; Simek, Smith 1997: 566), while the portion of knives in Veternica is negligible. The difference in the amount of knives can be a consequence of the modes of production, because no cobble wedge cores were produced for group A in Veternica, but only during quartz reduction. Because of the way the cobble is circularly knapped, naturally-backed knives are commonly produced during the cobble wedge core reduction (Simek 1991: 66). Moreover, the Upper Paleolithic types are poorly represented in Krapina, while they constitute the second most numerous category in the grouped typology of Veternica.

Certain similarities with the lithic assemblage of Veternica can also be seen in the lithic industry of the Petrovaradin Fortress (Petrovaradinska tvrđava) in Serbia, generally dated to the period from the beggining of MIS 3 to MIS 6 (Mihailović 2009: 129). With the use of chert on that site, quartz artefacts are well represented, but not prevalent (Mihailović 2009: PI. 2: 69). Furthermore, the composition of tools in the Petrovaradin Fortress also testifies to the predominance of various scrapers, notches and denticulates and Upper Paleolithic types (Mihailović 2014: 44). However, the total tool assemblage of the Petrovaradin Fortress has a lesser portion of scrapers and a larger portion of notches and denticulates and Upper Paleolithic types than Veternica (Mihailović 2009: PI. 16: 75). On the other hand, there are certain differences in the technology of reduction or flake production between the two assemblages. The Petrovaradin Fortress includes the use of the Levallois technique and the reduction of roughly prepared cores or large flakes and the knapping of large cores with one platform, while there are fewer Kombewa cores and no irregular cores with multidirectional reduction (Mihailović 2009: 99-102). On the other hand, no unambiguous traces of the Levallois or Kombewa technology have been determined in Veternica, where centripetal cores without knapping face preparation predominate, and irregular cores were also noted.

The comparison of Veternica industry to that of Betalov spodmol in Slovenia is of great interest. The industry of horizon B from Betalov spodmol, dated to the Riss/Würm interglacial (Brodar 2009: 113), significantly differs from the Veternica assemblage. The predominant technique in horizon $B$ is the Levallois, and there are numerous blade-like flakes (Brodar 2009: 106; Osole 1991: 23). In typological terms, Mousterian points are numerous there, but rare in Veterni- 
kvarca, iako nisu prevladavajuće (Mihailović 2009: T. 2: 69). Uz to, sastav oruđa Petrovaradinske tvrđave također svjedoči o prevlasti različitih oblika strugala, udubaka i nazubaka te gornjopaleolitičkih tipova (Mihailović 2014: 44). Međutim, u ukupnome skupu oruđa Petrovaradinske tvrđave strugala čine manji udio nego u Veternici, dok veći čine udupci i nazupci te gornjopaleolitički tipovi (Mihailović 2009: T. 16: 75). S druge strane, između dva navedena skupa postoje određene razlike u tehnologiji lomljenja, odnosno proizvodnje odbojaka. U Petrovaradinskoj tvrđavi zabilježeno je korištenje levaloaškoga proizvodnog postupka, lomljenje ugrubo pripremljenih jezgara ili velikih odbojaka, lomljenje velikih jezgara s jednom udarnom plohom, dok se u manjem udjelu javljaju jezgre tipa Kombewa, a nepravilne jezgre $s$ višesmjernim lomljenjem nisu primijećene (Mihailović 2009: 99-102). Nasuprot tome, u Veternici levaloaški proizvodni postupak i postupak Kombewa nisu nedvojbeno zabilježeni, već prevladavaju centripetalne jezgre bez pripreme strane lomljenja, a zabilježene su i nepravilne jezgre.

Vrlo je zanimljiva i usporedba industrije iz Veternice i onih iz Betalovoga spodmola u Sloveniji. Naime, industrija horizonta B iz Betalovoga spodmola, koja se datira u interglacijal Riss/Würm (Brodar 2009: 113), znatno se razlikuje od veterničkoga skupa. U horizontu B prevladavajući proizvodni postupak je levaloaški, a u velikoj se mjeri javljaju sječivoliki odbojci (Brodar 2009: 106; Osole 1991: 23). U tipološkome smislu vrlo su brojni mustjerski šiljci, kojih u Veternici nema mnogo, a nešto manje zastupljena su strugala (Brodar 2009: 106; Osole 1991: 23). Nasuprot tome, horizont C vrlo je sličan veterničkoj industriji jer je levaloaški proizvodni postupak rijedak, a prevladava obično lomljenje kojim su uglavnom proizvedeni široki odbojci. Sirovina je najčešće prikupljana u obliku oblutaka, što je vidljivo iz okorine koja se javlja na dosta izrađevina. Uz to, najbrojniji tipovi su strugala koja čine udio od čak 85\% svih oruđa (Brodar 2009: 106; Osole 1991: 24). Sličnost je vidljiva i s horizontom D Betalovoga spodmola u kojem je proizvodni postupak jednak kao i u horizontu C. Strugala su također najbrojnija kategorija oruđa, ali se u odnosu na horizont $C$ javljaju s manjim udjelom (66\%). Osim strugala, česti su i noževi s prirodnim hrptom (Brodar 2009: 107; Osole 1991). Horizonti C i D datirani su u prvu fazu glacijala Würm (Brodar 2009: 113), pa su stoga okvirno kronološki paralelni sa slojevima I i H iz Veternice.

S druge strane, skupovi litičkih artefakata s nalazišta Divje Babe I, također u Sloveniji, ne pokazuju značajne sličnosti s nalazima iz Veternice. lako se u Divjim Babama I nalaze paleolitički horizonti koji se okvirno datiraju od MIS 5 do MIS 3, horizonti koji pripadaju interglacijalu i ranom glacijalu (MIS 5) sadrže premali uzorak artefakata za primjerenu usporedbu (Turk 2014: 154). Najraniji horizonti s kojima je moguće napraviti usporedbu su E1 i E2. E2 horizont datira se na oko 73.000 , dok se E1 datira na oko 70.000 godina prije sadašnjosti (MIS 4) (Turk 2014: 154). U oba horizonta prevladavaju kategorije strugala, gornjopaleolitičkih tipova, nazubaka i odbojaka sa strmom obradbom (Turk 2014: 167). Za razliku od Veternice, strugala u horizontima E1 i E2 ne prelaze udio od 30\% (11,9\% za E2 i 27,1\% za sloj E1), a gornjopaleolitički tipovi su gotovo dvostruko više zastupljeni (u E2 25,4\%, a u E1 27,1\%). Nazupci su u horizontu E2 najbrojnija kategorija (34\%), a u E1 su također vrlo brojni (25,4\%). Odbojci sa strmom obradbom gotovo su jednako zastupljeni u ca, and scrapers are somewhat less numerous (Brodar 2009: 106; Osole 1991: 23). In contrast, horizon $C$ is very similar to the Veternica industry because the Levallois method is rare and there is a dominance of casual knapping, from which wide flakes were generally produced. Raw materials were commonly procured in the form of cobbles, visible from cortex, which is present on a lot of artefacts. Furthermore, the most numerous types are scrapers, constituting some 85\% of all the tools (Brodar 2009: 106; Osole 1991: 24). There is also a similarity with horizon D from Betalov spodmol, in which the mode of production is the same as in horizon $C$. Likewise, scrapers are the most numerous category of tools, but in relation to horizon $C$, scrapers have a lower percentage (66\%). Besides scrapers, naturally-backed knives are also common (Brodar 2009: 107; Osole 1991). Horizons C and $\mathrm{D}$ are dated to the first phase of the Würm glacial (Brodar 2009: 113) and are thus generally chronologically parallel with layers I and $\mathrm{H}$ in Veternica.

On the other hand, lithic assemblages from the site of Divje Babe I, also in Slovenia, do not show significant similarities with the finds from Veternica. Although there are Paleolithic levels which are generally dated to the period from MIS 5 to MIS 3, the sample of artefacts from the levels belonging to the interglacial and early glacial (MIS 5) is too small for adequate comparison (Turk 2014: 154). The earliest levels with which it is possible to make a comparison are E1 and E2. E2 level is dated to about 73.000, while E1 to 70.000 BP (MIS 4) (Turk 2014: 154). Categories of scrapers, Upper Paleolithic types, denticulates and flakes with abrupt retouch prevail in both levels (Turk 2014: 167). Unlike Veternica, scrapers in levels E1 and E2 do not exceed 30\% (11.9\% for E2 and 27.1\% for E1), and Upper Paleolithic types are almost twice as numerous (25.4\% in E2 and $27.1 \%$ in E1). Denticulates are the most numerous category in level E2 (34\%) and are also very numerous in E1 (25.4\%). Flakes with abrupt retouch are almost equally well represented in both levels (about 22\%) (Turk 2014: 167). Furthermore, even though discoid cores are the most common of all the Paleolithic levels of the site, Levallois cores are also very common there, but completely absent in Veternica (Turk, Turk 2014: 59). Regarding the raw material composition, chert, tuff and diabase predominate on the site (Turk et al. 2014: 37-38).

Even though there are several Middle Paleolithic sites in northern Bosnia, only two provide enough reliable data for a comparison with Veternica. Northern Bosnian sites have commonly been affected by erosion, because of which Middle Paleolithic artefacts are often mixed with Upper Paleolithic ones. Also, the recovery of finds in the frame of excavations has often been of a selective character (Baumler 1987: 172-174). Because of the above stated circumstances it is difficult today to acquire reliable information from assemblages from Londža, Kamen, and Pećine (Montet-White 1996: 85), and even harder to compare them to other sites. On the other hand, the site of Zobište provided a large enough sample in a secure context, dated approximately from 85.000 to 60.000 BP (from MIS 5a to MIS 4) (Baumler 1987: 33). At Zobište, radiolarite cobbles were gathered as raw materials from the nearby River Ukri- 
oba horizonta (oko 22\%) (Turk 2014: 167). Nadalje, iako su na nalazištu u svim paleolitičkim slojevima najčešće diskoidne jezgre, vrlo su česte i levaloaške koje u Veternici u potpunosti nedostaju (Turk, Turk 2014: 59). U sastavu sirovina, na nalazištu prevladavaju rožnjak, tuf i dijabaz (Turk et al. 2014: 37-38).

lako je u sjevernoj Bosni pronađeno nekoliko srednjopaleolitičkih nalazišta, samo dva pružaju dovoljno pouzdanih podataka za usporedbu s Veternicom. Naime, nalazišta sjeverne Bosne često su bila pod utjecajem erozija, pa su srednjopaleolitički nalazi nerijetko pomiješani s gornjopaleolitičkim. Uz to, prikupljanje nalaza u okviru istraživanja često je bilo selektivnoga karaktera (Baumler 1987: 172-174). Zbog gore navedenih okolnosti danas je teško iz skupova nalaza s Londže, Kamena i Pećina dobiti pouzdane informacije (Montet-White 1996: 85), a još manje je moguće uspoređivati ih s drugim nalazištima. S druge strane, nalazište Zobište dalo je dovoljno velik uzorak u sigurnome kontekstu, a otprilike se datira od 85.000 do 60.000 godina prije sadašnjosti (od MIS 5a do MIS 4) (Baumler 1987: 33). U Zobištu su kao sirovine prikupljani obluci radiolarita u obližnjoj rijeci Ukrini (Baumler 1988: 260). Tehnologija proizvodnje odbojaka, navedena ranije $u$ tekstu, sastojala se od početnoga jednosmjernog lomljenja koje se zatim u kasnijim fazama mijenjalo u centripetalno lomljenje (Baumler 1987: 166-168; 1988: 271), a sličan je proizvodni postupak možda bio prisutan i u Veternici, iako bi tu mogućnost valjalo detaljnije istražiti. U svakome slučaju, dio jezgara u Zobištu svjedoči i o prisutnosti levaloaškoga proizvodnog postupka u završnoj fazi redukcijskog niza (Baumler 1988: 262), što u Veternici nije posvjedočeno. Od Bordesovih tipova, u Zobištu prevladavaju levaloaški artefakti (25\%), strugala (23,2\%), prirodni noževi hrptenjaci (18\%), gornjopaleolitički tipovi (8,9\%) i nazupci (7,1\%) (Baumler 1987: 92). Prema tome, skup oruđa ne pokazuje velike sličnosti s Veternicom gdje su u odnosu na Zobište strugala dvostruko zastupljenija, prirodni noževi hrptenjaci rijetki, a levaloaški proizvodi u potpunosti izostaju. Srednjopaleolitičko nalazište Visoko Brdo u sjevernoj Bosni datira se okvirno kao i Zobište (Baumler 1987: 180). Redukcijski niz pomalo je drugačiji od onoga u Zobištu, jer su obluci razokorivani iz više smjerova, ali je ostatak redukcije tekao kao i u Zobištu (Baumler 1987: 191; Montet-White 1996: 84-85). U skupu oruđa prevladavaju strugala s oko $30 \%$, a dobro su zastupljeni i levaloaški odbojci i prirodni noževi hrptenjaci (Baumler 1987: 182).

Sličnosti su primjetne i s nalazištem Érd u Mađarskoj. U njegovome litičkom skupu javlja se centripetalno lomljenje od jedne ili dvije strane jezgre te proizvodni postupak Quina, odnosno proizvodnja debelih odbojaka asimetričnoga presjeka od dvije dodirujuće strane jezgre, dok levaloaški proizvodni postupak nije zabilježen (Mester, Moncel 2006: 225). Kao što je već navedeno, centripetalno lomljenje na jednoj ili dvije strane jezgre primijećeno je i u Veternici, kao i nedostatak levaloaškoga postupka, ali nije posvjedočen proizvodni postupak Quina kakav je zabilježen u Érdu. U Érdu je kao sirovina uglavnom korišten kvarcit (78,05\% ukupnoga skupa), u prvome redu u obliku oblutaka (Mester, Moncel 2006: 226). Među oruđem, slično kao i u Veternici, prevladavaju strugala s udjelom od 65\% (Mester 2012: 9). Cijeli je skup okvirno datiran u vrijeme kasnoga interglacijala i početka zadnjega glacijala (Mester, Moncel 2006, 222). na (Baumler 1988: 260). The technology of flake production, mentioned earlier in the text, consisted of initial unipolar flaking which subsequently in later phases changed into centripetal flaking (Baumler 1987: 166-168; 1988: 271), and similar production methods were perhaps present in Veternica, though this possibility should be studied in more detail. In any case, part of the cores from Zobište testifies to the presence of the Levallois method in the final phase of the reduction sequence (Baumler 1988: 262), which is not seen in Veternica. Among Bordes's types, Levallois elements (25\%), scrapers (23.2\%), naturally-backed knives (18\%), Upper Paleolithic types (8.9\%) and denticulates (7.1\%) predominate in Zobište (Baumler 1987: 92). Accordingly, the tool assemblage does not display great similarities with Veternica, where the share of scrapers is two times larger than in Zobište, naturally-backed knives are rare, and Levallois products are completely absent. The Middle Paleolithic site of Visoko Brdo in northern Bosnia is generally dated the same as Zobište (Baumler 1987: 180). The reduction sequence is somewhat different than Zobište, because the cobbles were decortified in a multidirectional manner, but the rest of the reduction proceeded as in Zobište (Baumler 1987: 191; Montet-White 1996: 84-85). In the tool assemblage, scrapers predominate at about $30 \%$, and Levallois flakes and naturally-backed knives are well represented (Baumler 1987: 182).

There are noticeable similarities with the site of Érd in Hungary. Its lithic assemblages have centripetal reduction on one or both core faces and the Quina method or production of thick flakes with asymmetrical cross-sections from two tangent core faces, while the Levallois method has not been identified (Mester, Moncel 2006: 225). As already mentioned, centripetal flaking on one or both core faces was also noticed in Veternica, as was the absence of the Levallois method, but the Quina method, as described for Érd, was not recognized. The main raw material used in Érd is quartzite $(78.05 \%$ of the entire assemblage), primarily in the form of cobbles (Mester, Moncel 2006: 226). Similarly as in Veternica, the prevailing tools are scrapers at 65\% (Mester 2012: 9). The entire assemblage is generally dated to the last interglacial and the beginning of the last glacial (Mester, Moncel 2006: 222). Along with Érd, we should mention the site of Tata from Hungary, dated to the time of MIS 5 (Borel et al. 2017: 5). The lithic industry of Tata shows certain similarities with Veternica. The production method is not Levallois, and centripetal cores and cores with two opposite flaking faces made from cobbles predominate (Borel et al. 2017: 6, 8). Scrapers and déjeté points predominate among retouched tools, but there are also denticulates, notches, endscrapers, truncations, burins and borers (Borel et al. 2017: 9). But what makes the lithic assemblage of Tata very different from Veternica is the prevalence of small flakes with the maximum dimensions of less than 3 centimeters (Borel et al. 2017: 9). Small flakes were intentionally produced and used as tools, but not as a consequence of the exclusive use of small-sized cobbles (Borel et al. 2017: 15). Because of such traits, the industry of Tata is characterized as microlithic and related to a Central European variant of the Mousterian culture (Tau- 
Uz Érd, u Mađarskoj valja spomenuti i nalazište Tata koje se datira u vrijeme MIS 5 (Borel et al. 2017: 5). Litička industrija Tate pokazuje određene sličnosti s Veternicom. Naime, proizvodni postupak nije levaloaški, već prevladavaju centripetalne jezgre i jezgre $s$ dvije nasuprotne strane lomljenja napravljene na oblucima (Borel et al. 2017: 6, 8). Među oruđem s obradbom prevladaju strugala i kutni šiljci, a prisutni su i nazupci, udupci, grebala, zarupci, dubila i svrdla (Borel et al. 2017: 9). Međutim, ono što čini litički skup artefakata Tate vrlo različitim od Veternice jest prevlast malih odbojaka čija je maksimalna dimenzija manja od 3 centimetra (Borel et al. 2017: 9). Mali odbojci namjerno su proizvedeni te korišteni kao oruđa, ali ne kao posljedica isključivoga korištenja oblutaka malih dimenzija (Borel et al. 2017: 15). Zbog takvih značajki industrija Tate okarakterizirana je kao mikrolitička te dovedena u vezu sa srednjoeuropskom varijantom mustjerske kulture (taubahijen ili taubaška industrija) (Borel et al. 2017: 6).

Nažalost, zbog nedostatka sustavnih litičkih analiza zasad nije moguće usporediti litičke skupove Veternice i one iz ranijih slojeva Vindije, iako je poznato da se sloj K iz Vindije datira na oko 114.000 godina prije sadašnjosti te ima zabilježene tragove levaloaškoga proizvodnog postupka (Ahern et al. 2004: 61). Osim toga, većina sirovine u Vindiji također je prikupljana u obliku oblutaka (Blaser et al. 2002: 391-392; Kurtanjek, Marci 1990: 234), a kvarc je u svim srednjopaleolitičkim slojevima najzastupljenija sirovina (Blaser et al. 2002: 393). Također, nije moguće napraviti pouzdanu usporedbu sa srednjopaleolitičkim skupom iz Velike pećine zbog maloga broja nalaza s toga lokaliteta (Karavanić, Smith 1998: 236).

\subsection{Tip mustjerske kulture}

$\mathrm{Na}$ temelju karakteristika litičkoga skupa nalaza i usporedbe $s$ drugim istovremenim nalazištima u susjednim regijama nastojalo se industriju Veternice pripisati određenome tipu mustjerske kulture. Međuim, određivanje tipa mustjerske kulture popraćeno je stanovitim problemima. Naime, različite značajke litičkoga skupa Veternice naizgled podupiru smještanje industrije u tipični musterijen ili u šarentijenski tip mustjerske kulture. Udio strugala u ukupnoj količini oruđa iznosi otprilike $50 \%$, što se nalazi blizu granice razlikovanja između dvije navedene inačice, pri čemu tipični musterijen u sastavu oruđa ima između 25 i 55\% strugala, a šarentijen od 50 do 80\% (Bordes 1961: 805; 1968: 101). Na prostoru Francuske postoje i razlike između pojedinih varijanti mustjerske kulture u odnosu poprečnih naprema bočnim strugalima, pri čemu postotak poprečnih strugala u tipu Quina iznosi od 20 do 30\%, a u svim ostalim tipovima od 5 do 15\% (Dibble 1988: Fig. 10.6; Mellars 1996: 109). Kada se broj svih tipova poprečnih strugala podijeli s brojem svih oblika jednostranih, dvostrukih i izmjeničnih strugala te strugala na ravnoj strani i onih s obostranom obradbom, taj postotak za industriju Veternice iznosi otprilike 18\%. Prema tome, taj udio je manji od prosjeka tipa Quina, ali veći je u odnosu na prosjek ostalih tipova mustjerske kulture. Valja napomenuti da je samo na jednome oruđu primijećena Quina obradba (T. 1: 2). S druge strane, u litičkoj industriji Veternice nije primijećena prisutnost levaloaškoga postupka, što ide u prilog svrstavanja njezine industrije u šarentijen, odnosno tip Quina (Bordes 1968: 101; Mellars 1996: 73). bachian) (Borel et al. 2017: 6).

Unfortunately, because of the absence of systematic lithic analyses, it is not possible, for the time being, to compare the lithic assemblage of Veternica with those from the earlier layers of Vindija, although it is known that layer $\mathrm{K}$ from Vindija dates to about 114.000 years BP and has noted remains of the Levallois method (Ahern et al. 2004: 61). Besides that, most raw materials form Vindija were also procured in the form of cobbles (Blaser et al. 2002: 391-392; Kurtanjek, Marci 1990: 234), and quartz is the most numerous raw material in all the Middle Paleolithic layers (Blaser et al. 2002: 393). Likewise, it is not possible to conduct a reliable comparison with the Middle Paleolithic assemblage from Velika Pećina because of the small number of finds from that site (Karavanić, Smith 1998: 236).

\subsection{Type of Mousterian culture}

Based on the characteristics of the lithic assemblage and the comparison with other contemporary sites in neighbouring regions, it was endeavoured to attribute the industry of Veternica to a certain type of the Mousterian culture. However, determining the type of the Mousterian culture entails certain problems. Different characteristics of the lithic assemblage of Veternica seemingly support the attribution of the industry to either the typical Mousterian or the Charentian type of the Mousterian culture. The portion of scrapers in the total amount of tools is about $50 \%$, which is close to the limit of differentiation between the two mentioned variants, in which the typical Mousterian has between 25 and 55\% scrapers in the tool composition and the Charentian has between 50 and 80\% (Bordes 1961: 805; 1968: 101). In France, different variants of the Mousterian culture differ in the ratio of transverse scrapers versus sidescrapers, where the percentage of transverse scrapers is between 20 and 30\% in Quina types, and between 5 and 15\% in all other types (Dibble 1988: Fig. 10.6; Mellars 1996: 109). When the number of all transverse scraper types is divided by the number of all the forms of single and double sidescrapers, alternate sidescrapers, scrapers on the interior side, and those with bifacial retouch, this percentage is about $18 \%$ for the Veternica industry. This percentage is smaller than the average of the Quina type, but larger than the average of the remaining variants of the Mousterian culture. It must be mentioned that the Quina retouch has been noticed on only one tool (PI. 1:2). On the other hand, the Levallois method has not been recorded in the lithic industry of Veternica, which supports its attribution to the Charentian, or more precisely, to the Quina type (Bordes 1968: 101; Mellars 1996: 73).

Kozłowski (1992: Figs. 1-2) mentions that there existed a Charentian of the Krapina-Veternica type during the MIS 5e interglacial in the Balkans, even though northwestern Croatia is located outside the Balkan peninsula, but he does not mention the characteristics by which their industries were recognized as Charentian. Mihailović (2014: 68) mentions that the sites of Krapina, Veternica, and Vindija in Croatia, Betalov spodmol in Slovenia, and Érd in Hungary, are cha- 
Kozłowski (1992: Figs.1-2) navodi da se u vrijeme interglacijala MIS 5e na prostoru Balkana nalazi šarentijen tipa Krapina - Veternica, premda se prostor sjeverozapadne Hrvatske nalazi izvan područja tzv. Balkanskoga poluotoka, ali ne navodi koje su karakteristike prema kojima su njihove industrije prepoznate kao šarentijenske. Mihailović (2014: 68) navodi da su nalazišta Krapina, Veternica i Vindija u Hrvatskoj, Betalov spodmol u Sloveniji i Érd u Mađarskoj okarakterizirana zastupljenošću šarentijenskih elemenata, s umjerenom prisutnošću ili izostankom levaloaškoga postupka te korištenjem kvarca i kvarcita za proizvodnju oruđa. Takvom tipu industrije pridodani su i skupovi Petrovaradinske tvrđave, Balanice, Pešturine i slojevi XXII-XX Crvene stijene, iako se u Petrovaradinskoj tvrđavi miješaju elementi šarentijenskih, levaloaških i srednjoeuropskih industrija (Mihailović 2014: 68). Međutim, jednako kao u Veternici na istim nalazištima u većini slučajeva nisu zabilježene značajke tipa Quina, ponajprije oruđa s Quina obradbom (Mihailović 2014: 68). Stoga Mihailović (2014: 68-69) smatra da se na prostoru jugoistočne Europe ne radi o šarentijenu u užem smislu, ali se na navedenim nalazištima javljaju šarentijenski elementi i nestaju nakon MIS 5 i MIS 4. Šarentijenski karakter industrije iz Krapine također spominju Simek, Smith (1997: 566), iako je ranije Simek (1991: 62) isti litički skup pripisao tipičnome musterijenu. Simek, Smith (1997: 566) navode da se industrija iz Krapine treba svrstati u "generični“ šarentijen koji je bogat strugalima jer nema dovoljno levaloaških izrađevina da bi bila pripisana tipu Ferrassie, a s druge strane uopće nije primijećena Quina obradba da bi ju bilo moguće pripisati tipu Quina. Skupovi iz horizonata C i D Betalovoga spodmola kojima je Veternica vrlo slična, također su svrstani u šarentijen (Osole 1991). lako Brodar (2009: 111) odbacuje ideju o šarentijenskom karakteru tih horizonata, čini se da to radi prvenstveno zbog problematične terminologije i pogrešnoga povezivanja srednjoeuropskih varijanti mustjerske kulture s onima iz Francuske. Naime, Brodar (2009: 111) smatra da strugala iz horizonata $C$ i $D$ Betalovoga spodmola nisu nimalo slična strugalima tipa Quina s eponimnoga nalazišta La Quina u Francuskoj, pa se stoga ni industrije Betalovoga spodmola prema navedenome autoru ne smiju povezivati s šarenijenskim industrijama Francuske. Ovaj stav je opravdan, ali autori ovoga rada zasad i dalje koriste termin šarentijen zbog uvriježenosti naziva u literaturi koja navodi značajke toga tipa mustjerske kulture na prostoru jugoistočne Europe (Broglio, Kozłowski 1987: 146; Mihailović 2014: 67-70), bez da nužno impliciraju povezanost pojedinih varijanti mustjerske industrije srednje i jugoistočne Europe s onima iz zapadne. Čini se da se litička industrija Veternice na temelju prevlasti strugala, zastupljenosti poprečnih strugala u odnosu na ostala strugala, nedostatka levaloaškoga proizvodnog postupka, korištenja kvarca te sličnosti s industrijama Krapine, Betalovoga spodmola, Érda i Petrovaradinske tvrđave može pripisati šarentijenu u širem smislu, iako udio strugala ulazi i u okvire tipičnoga musterijena. Zbog nedostatka karakterističnih strugala tipa Quina, ova industrija ne može se povezati s mustjerskom kulturom tipa Quina. Naposljetku, potrebno je naglasiti da nije moguće razjasniti je li trenutni sastav oruđa rezultat pomiješanosti slojeva te javljaju li se u pojedinim slojevima različiti tipovi mustjerske kulture. racterized by charentoid elements, with a moderate presence or absence of the Levallois method and with the use of quartz and quartzite for tool production. This type of industry includes the assemblages of the Petrovaradin Fortress, Balanica, Pešturina, and layers XXII-XX of Crvena stijena, even though the Petrovaradin Fortress has mixed elements of charentoid, levalloisian and central European industries (Mihailović 2014: 68). However, as in Veternica, the same sites mostly do not have recorded characteristics of the Quina type, primarily tools with Quina retouch (Mihailović 2014: 68). Thus, Mihailović (2014: 68-69) argues, there is no Charentian sensu stricto in Southeast Europe, but charentoid elements appear and then disappear on the mentioned sites after MIS 5 and MIS 4. The Charentian character of Krapina was suggested by Simek, Smith (1997: 566), although earlier Simek (1991: 62) attributed the same lithic assemblage to the typical Mousterian. Simek, Smith (1997: 556) mention that the industry of Krapina should be attributed to the "generic" Charentian which is rich in scrapers, because there are not enough Levallois products to be attributed to the Ferrasie type, and, on the other hand, no Quina retouch for the possibility of attributing it to the Quina type. The assemblages from horizons $C$ and $D$ of Betalov spodmol, to which Veternica is very similar, were also attributed to the Charentian (Osole 1991). Although Brodar (2009: 111) rejects the idea of the charentoid character of these horizons, it seems that he does it primarily on the grounds of problematic terminology and false connection of the Central European variants of the Mousterian with those from France. In fact, Brodar (2009: 111) argues that the scrapers from horizons $C$ and $D$ of Betalov spodmol are not in the slightest similar to the Quina scrapers from the eponymous site of La Quina in France, and thus, according to the mentioned author, the industries of Betalov spodmol must not be connected to the Charentian industries of France. This stance is not without justification, but the authors of this work continue to use the term Charentian because of the inveteracy of the name in the literature that also lists the characteristics of that type of the Mousterian in Southeast Europe (Broglio, Kozłowski 1987: 146; Mihailović 2014: 67-70), without necessarily implying the connection of specific variants of the Mousterian of Central and Southeast Europe to those of Western Europe. It seems that the lithic industry of Veternica can be attributed to the Charentian sensu lato on the basis of scraper prevalence, the presence of transverse in relation to other scrapers, the absence of the Levallois method, the use of quartz, and the similarities with the industries of Krapina, Betalov spodmol, Érd, and the Petrovaradin Fortress, even though scraper percentages overlap with the criteria of the typical Mousterian. Because of the absence of characteristic Quina scrapers, this industry cannot be attributed to the Quina Mousterian. Finally, it is necessary to emphasize that it is not possible to clarify if the current tool composition is the result of mixed finds and if different variants of the Mousterian appear in different layers. 


\section{SAŽETAK REZULTATA}

Litička analiza srednjopaleolitičkih izrađevina špilje Veternice pokazala je, unatoč nemogućnosti razdvajanja nalaza po stratigrafskim jedinicama, velik potencijal nalazišta za razumijevanje srednjega paleolitika na prostoru sjeverozapadne Hrvatske i susjednih regija. Tehnologija pokazuje prilagodbu proizvodnih postupaka s obzirom na korištene sirovine. Uz prevladavajuću proizvodnju oruđa na samome nalazištu, zabilježen je i import nekoliko nalaza što svjedoči o mobilnosti, a možda i o kontaktima između različitih grupa. Špilja je vjerojatno služila kao bazno stanište malobrojnim neandertalskim zajednicama, ali nije moguće sa sigurnošću utvrditi koliko su dugo trajale faze nastanjivanja. Zbog sličnosti litičkih skupova Veternice i drugih nalazišta iz vremena interglacijala i ranoga glacijala na prostoru srednje i jugoistočne Europe, potvrđuje se ranija interpretacija datiranja pojedinih slojeva (Miracle, Brajković 2010: 220). Sloj J ostaje datiran u vrijeme interglacijala MIS 5e, a kako slojeve I i H zasad nije moguće preciznije datirati, ostaju okvirno datirani u vremenuod MIS 4 do MIS $5 a-d$. Na temelju sastava oruđa, korištenja sirovina, tehnologije i sličnosti s drugim nalazištima na prostoru jugoistočne i srednje Europe, industrija Veternice pripisana je šarentijenu u širem smislu. U svakome slučaju, karakteristike litičkoga skupa Veternice odražavaju prilagodbe neanderatalaca na specifične okolišne i klimatske uvjete koji su u vrijeme interglacijala i ranoga glacijala vladali na prostoru sjeverozapadne Hrvatske i susjednih regija, kao i kulturne tradicije koje su prisutne i na drugim nalazištima toga prostora.

\section{ZAHVALE}

Rad na litičkome materijalu iz Veternice omogućila je upraviteljica Zavoda za paleontologiju i geologiju kvartara HAZU, Jadranka Mauch-Lenardić. Dražen Kurtanjek uvelike je pomogao oko određivanja kamenih sirovina. Za izradu i doradu crteža i fotografija nalaza zaslužni su Mateo Petrović, Dalibor Branković i Joško Barbarić. Svima im duboko zahvaljujemo na pomoći.

\section{SUMMARY OF THE RESULTS}

The lithic analysis of the Middle Paleolithic artefacts from Veternica, despite the impossibility of separating finds according to stratigraphic units, showed great potential of the site in understanding the Middle Paleolithic in northwestern Croatia and neighbouring regions. The technology shows an adaptation of reduction methods to the used raw materials. With the prevalent production of tools on-site, the import of several finds is also noted, which testifies to the mobility and perhaps contacts between different groups. The cave was probably used as a base camp for smallscale Neanderthal groups, but it is not possible to claim with certainty how long the phases of occupation lasted. The similarity of the lithic assemblage of Veternica to other interglacial and early glacial sites in Central and Southeast Europe confirms the earlier interpretation of the dating of specific layers (Miracle, Brajković 2010: 220). Layer J remains dated to the MIS 5e interglacial, and as layers I and $\mathrm{H}$ cannot be dated more precisely, they remain generally dated to the period from MIS 4 to MIS $5 \mathrm{a}-\mathrm{d}$. On the basis of tool composition, raw-material use, technology, and similarities with other sites in Central and Southeast Europe, the industry of Veternica is attributed to the Charentian sensu lato. In any case, the characteristics of the lithic assemblage of Veternica reflect the adaptation of the Neanderthals to the specific environmental and climatic conditions that were present in the interglacial and early glacial of northwestern Croatia and the neighbouring regions, as well as the cultural traditions which are also present at other sites in that area.

\section{ACKNOWLEDGEMENTS}

The work on the lithic material from Veternica was made possible by the director of the Institute for Quaternary Paleontology and Geology of the Croatian Academy of Sciences and Arts, Jadranka Mauch-Lenardić. Dražen Kurtanjek greatly assisted us in determining stone raw materials. Mateo Petrović, Dalibor Branković, and Joško Barbarić were responsible for the creation and modification of illustrations and photographs. We thank them all sincerely for their help.

\author{
Prijevod / Translation \\ Marko Banda \\ Lektura / Proofreading \\ Marko Maras
}




\section{LITERATURA / BIBLIOGRAPHY}

Ahern, J. C. M., Karavanić, I., Paunović, M., Janković, I., Smith, F. H. 2004, New discoveries and interpretations of hominid fossils and artifacts from Vindija Cave, Croatia, Journal of Human Evolution, Vol. 46(1), 27-67. doi: 10.1016/j.jhevol.2003.09.010

Baumler, M. F. 1987, Core Reduction Sequences: An Analysis of Blank Production in The Middle Paleolithic of Northern Bosnia (Yugoslavia), Unpublished PhD Thesis, University of Arizona, Tuscon.

Baumler, M. F. 1988, Core Reduction, Flake Production, and the Middle Paleolithic Industry of Zobište (Yugoslavia), in: Upper Pleistocene Prehistory of Western Eurasia, Dibble H., Montet-White A. (eds.), University of Pennsylvania Press, Philadelphia, 255-274.

Blaser, F., Kurtanjek, D., Paunović, M. 2002, L'industrie du site néandertaliende la grotte de Vindija (Croatie): une révision des matières premières lithiques, L'Anthropologie, Vol. 106(3), 387-398.

Boëda, E. 1995, Levallois: A Volumetric Construction, Methods, A Technique, in: The Definition and Interpretation of Levallois Technology, Dibble H. L., Bar-Yosef O. (eds.), Monographs in World Archaeology 23, Prehistory Press, Madison, 41-68.

Bordes, F. 1961, Mousterian cultures in France, Science, Vol. 134 (3482), $803-810$.

Bordes, F. 1968, The Old Stone Age, World University Library, McGraw-Hill, New York.

Borel, A., Dobosi, V., Moncel, M.-H. 2017, Neanderthal's microlithic tool production and use, the case of Tata (Hungary), Quaternary International, Vol. 435(A), 5-20. doi.org/10.1016/j.quaint.2015.09.102

Božić, V. 2003, Speleologija u Hrvatskoj: Speleološki priručnik, Hrvatski planinarski savez, HPD „Željezničar", Zagreb.

Božičević, S. 1961, Pećina Veternica nekada, sada i u budućnosti, Naše planine - Revija Planinarskog saveza Hrvatske, god. XIII, br. 3/4, 74-92.

Božičević, S. 1995, Postaja br. 4: Pećina Veternica, in: Geološki vodič Medvednice, Šikić K. (ed.), Institut za geološka istraživanja, INA-Industrija nafte d.d., Zagreb, 48-49.

Brodar, M. 2009, Stara kamena doba v Sloveniji / Altsteinzeit in Slowenien, Inštitut za arheologijo, Ljubljana.

Broglio, A., Kozłowski, J. 1987, Il Paleolitico: Uomo, ambiente e culture, Jaca Book, Milano.

de Lombera-Hermida, A., Rodríguez-Rellán, C. 2016, Quartzes matter. Understanding the technological and behavioural complexity in quartz lithic assemblages, Quaternary International, Vol. 424, 2-11. doi.org/10.1016/j.quaint.2016.11.039

Debénath, A., Dibble, H. L. 1994, Handbook of Paleolithic Typology. Volume One: Lower and Middle Paleolithic of Europe, University Museum Press, Philadelphia.

Dibble, H. L. 1988, Typological aspects of reduction and intensity of utilization of lithic resources in the French Mousterian, in: UpperPleistocene Prehistory of Western Eurasia, Dibble H., Montet-White A. (eds.), University Museum Monographs 54, University of Pennsylvania, Philadelphia, 181-198.

Driscoll, K. 2010, Understanding quartz technology in early prehistoric Ireland, Unpublished PhD Thesis, University College Dublin School of Archaeology, Dublin.

Gorjanović-Kramberger, D. 1899, Krš Zagrebačke gore, Hrvatski planinar - Viestnik "Hrvatskoga planinarskoga družtva” u Zagrebu, god. II, br. 11, 161-164.

Hirc, D. 1903, U zapadnom prigorju Zagrebačke gore, Hrvatski planinar - Viestnik "Hrvatskoga planinarskoga družtva" u Zagrebu, god. IV, br. 1/2, 7-10.

Hirc, D. (ed.) 1905, Prirodni zemljopis Hrvatske. Knjiga prva: Lice naše domovine, Tisak i naklada Antuna Scholza, Zagreb.

Inizan, M. L., Reduron-Ballinger, M., Roche, H., Tixier, J. 1999, Technology and terminology of knapped stone, Vol. 5, Cercle de Recherches et d'Etudes Préhistoriques, Nanterre.

Karavanić, I., Golubić, V., Kurtanjek, D., Šošić, R., Zupanič, J. 2008, Litička analiza materijala iz Mujine pećine, Vjesnik za arheologiju i povijest dalmatinsku, Vol. 101(1), 29-58.

Karavanić, I., Smith, F. H. 1998, The Middle/Upper Paleolithic interface and the relationship of Neanderthals and early modern humans in the Hrvatsko Zagorje, Croatia, Journal of Human Evolution, Vol. 34(3), 223-248. doi.org/10.1006/jhev.1997.0192

Karavanić, I., Vukosavljević, N., Šošić Klindžić, R., Težak-Gregl, T., Halamić,
J., Bošnjak Botica, T., Nahod, B. 2015, Pojmovnik kamenoga doba, FF Press, Institut za hrvatski jezik i jezikoslovlje, Zagreb.

Kozłowski, J. K. 1992, The Balkans in the Middle and Upper Palaeolithic: the gate to Europe or a cul-de-sac?, Proceedings of the Prehistoric Society, Vol. 58, 1-20. doi: https://doi.org/10.1017/ S0079497X00004059

Kurtanjek, D., Marci, V. 1990, Petrografska istraživanja paleolitskih artefakata spilje Vindije, Rad Jugoslavenske akademije znanosti i umjetnosti, Vol. 449(24), 227-238.

Malez, M. 1955, Speleološka istraživanja u 1953. godini, Ljetopis Jugosla venske akademije znanosti i umjetnosti, Vol. 60 (1953), 281-289.

Malez, M. 1956a, Speleološka istraživanja u 1954. godini, Ljetopis Jugoslavenske akademije znanosti i umjetnosti, Vol. 61 (1954), 316-324.

Malez, M. 1956b, Geološka i paleonotološka istraživanja u pećini Veternici, in: Acta geologica I. (Prirodoslovna istraživanja Jugoslavenske akademije znanosti i umjetnosti), Ugrenović A. (ed.), Jugoslavenska akademija znanosti i umjetnosti, Zagreb, 83-88.

Malez, M. 1957, Paleontološko istraživanje pećine Veternice u 1955. godini, Ljetopis Jugoslavenske akademije znanosti i umjetnosti, Vol. 62 (1955), 280-294.

Malez, M. 1958, Neki noviji rezultati paleontološkog istraživanja pećine Veternice, Palaeontologia Jugoslavica 1, Jugoslavenska akademija znanosti i umjetnosti, Zagreb.

Malez, M. 1958/1959, Das Paläolithikum der Veternicahöhle und der Bärenkult, Quartär, Vol.11/12, 171-188.

Malez, M. 1963, Kvartarna fauna pećine Veternice u Medvednici, Palaeontologia Jugoslavica 5, Jugoslavenska akademija znanosti i umjetnosti, Zagreb.

Malez, M. 1965, Pećina Veternica u Medvednici. 1. Opći speleološki pregled. 2. Stratigrafija kvartarnih taložina, in: Acta geologica V. (Prirodoslovna istraživanja Jugoslavenske akademije znanosti i umjet nosti 35), Tajder M., Salopek M. (eds.), Jugoslavenska akademija znanosti i umjetnosti, Zagreb.

Malez, M. 1967, Paleolitska nalazišta Hrvatske, Arheološki vestnik, Vol. 18, 255-290.

Malez, M. 1972, Kvartargeološka i speleološka istraživanja u 1971. godini, Ljetopis Jugoslavenske akademije znanosti i umjetnosti, Vol. 76 (1971), 215-227.

Malez, M. 1974a, Noviji rezultati istraživanja paleolitika u Velikoj pećini, Veternici i Šandalji, Arheološki radovi i rasprave, Vol. 7, 7-44.

Malez, M. 1974b, Nova dostignuća u istraživanjima paleolitika u nekim pećinama Hrvatske, in: Acta Carsologica - Krasoslovni zbornik VI, Ilešič S. (ed.), Slovenska akademija znanosti in umetnosti, Ljubljana, 259-270.

Malez, M. 1979a, Nalazišta paleolitskog i mezolitskog doba u Hrvatkoj, in: Praistorija jugoslavenskih zemalja. I: Paleolitsko i mezolitsko doba, Benac A. (ed.), Akademija nauka i umjetnosti Bosne i Hercegovine, Centar za balkanološka ispitivanja, Sarajevo, 227-276.

Malez, M 1979b, Osnovne crte paleolitika i mezolitika u Hrvatskoj, Rad Jugoslavenske akademije znanosti i umjetnosti, Vol. 383, 117-153.

Malez, M. 1981, Paleolitik na području Zagreba, in: Arheološka istraživanja u Zagrebu i njegovoj okolici, Rapanić Ž. (ed.), Izdanja Hrvatskog arheološkog društva, sv. 6, 65-108.

Mellars, P. A. 1996, The Neanderthal legacy: an archaeological perspective from Western Europe, Princeton University Press, Princeton.

Mester, Z. 2012, Exploitation du quartzite à la station du Paléolithique moyen à Érd (Hongrie), Annales d'Université Valahia Targoviste: Section d'Archeologie et d'Histoire XIV(1), Cârciumaru M. (ed.), Valahia University Press, Târgovişte, 7-18.

Mester, Z., Moncel, M. H. 2006, Le site paléolithique moyen d'Érd (Hongrie): Nouvelles données sur les chaînes opératoires et résultats morpho-fonctionnels de la production, Anthropologie, Vol. 44(3), 221-240.

Mihailović, D. 2009, Srednjopaleolitsko naselje na Petrovaradinskoj tvrđavi: Okresana kamena industrija iz sektora I i ll (Iskopavanja 2003. i 2004. godine) / Middle Palaeolthic Setlement at Petrovaradin Fortress: Chipped Stone Industry from Sector I and II (Excavations in 2003 and 2004), Edicija Petrovaradin, sveska II, Muzej grada Novog Sada, Novi Sad.

Mihailović, D. 2014, Paleolit na centralnom Balkanu: kulturne promene ipopulaciona kretanja, Srpsko arheološko društvo, Beograd. 
Miracle, P. 1991, Carnivore Dens or Carnivore Hunts? A Review of Upper Pleistocene Mammalian Assemblages in Croatia and Slovenia, Rad Hrvatske akademije znanosti i umjetnosti: Razred za prirodne znanosti, 193-219.

Miracle, P. T., Brajković, D. 1992, Revision of the ungulate fauna and Upper Pleistocene stratigraphy of Veternica Cave (Zagreb, Croatia), Geologia Croatica, Vol. 45(1), 1-14. doi.org/10.4154/GC.1992.01

Miracle, P. T., Brajković, D. 2010, The palaeoecological significance of the Pleistocene mammalian fauna from Veternica Cave, Croatia. Revision of the lagomorpha, canidae, mustelidae and felidae, Geologia Croatica, Vol. 63(2), 207-224. doi: 104154/gc.2010.18

Miracle, P. T., Mauch Lenardić, J., Brajković, D. 2010, Last Glacial Climates, "Refugia", and Faunal Change in Southeastern Europe: Mammalian Assemblages from Veternica, Velika pećina, and Vindija Caves (Croatia), Quaternary international, Vol. 212(2), 137148. doi.org/10.1016/j.quaint.2009.06.003

Montet-White, A. 1996, Le paléolithique en ancienne Yougoslavie. Série "Préhistoire d'Europe", Editions Jérôme Millon, Grenoble.

Osole, F. 1991, Betalov spodmol, rezultati paleolitskih izkopavanj S. Brodarja. 2 del, Poročilo o raziskovanju paleolita, neolita in eneolita $v$ Sloveniji, Vol. XIX, 7-129.

Paunović, M. 1992, Život i djelo akademika Mirka Maleza, in: Mirko Malez 1924.-1990., Majer V. (ed.), Spomenica preminulim akademicima, sv. 66, Hrvatska akademija znanosti i umjetnosti, Zagreb, 12-18.

Perhoč, Z., Altherr, R. 2011, Litički nalazi s otoka Sušaca, Opvscvla archaeologica, Vol. 35(1), 7-39.

Poljak, J. 1934, Pećina Veternica u Zagrebačkoj gori, Priroda, Vol. 5, 133-139.

Radovčić, J., Škoberne, Ž. 1989, Zagreb prije početaka: najstarija prošlost grada i okolice, Mladost, Zagreb.

Rink, W. J., Schwarcz, H. P., Smith, F. H., Radovčić, J. 1995, ESR ages for Krapina hominids, Nature, Vol. 378 (6552), 24. doi: 10.1038/378024a0

Simek, J. F. 1991, Stone Tool Assemblages from Krapina (Croatia, Yugoslavia), in: Raw Material Economies among Prehistoric Hunter Gathe-

\section{INTERNETSKI IZVORI /INTERNET SOURCES}

Hrvatski speleološki poslužitelj, Popis najvećih špilja, http://speleologija. $\mathrm{hr} /$ popis (21. 01. 2019.) rers, Montet-White A., Holen A. (ed.), University of Kansas Publications in Anthropology 19, University of Kansas Press, Lawrence, 59-72.

Simek, J. F., Smith, F. H. 1997, Chronological changes in stone tool assemblages from Krapina (Croatia), Journal of Human Evolution, Vol. 32(6), 561-575. doi.org/10.1006/jhev.1996.0129

Turk, J., Turk, M., Turk, I. 2014, Surovine, uporabljene za izdelavo artefaktov / Raw materials used for making artefacts, in: Divje babe l: Paleolitsko najdišče mlajšega pleistocena v Sloveniji, Il. del: Arheologija I Divje babe I: Upper Pleistocene Palaeolithic site in Slovenia, Part II: Archaeology, Turk I. (ed.), Opera Instituti Archaeologici Sloveniae 29, Inštitut za arheologijo ZRC SAZU, Založba ZRC, Ljubljana, 37-56.

Turk, M. 2014, Tipologija kamnitih artefaktov / Typology of stone artefacts, in: Divje babe I: Paleolitsko najdišče mlajšega pleistocena v Sloveniji, II. del: Arheologija / Divje babe I: Upper Pleistocene Palaeolithic site in Slovenia, Part II: Archaeology, Turk I. (ed.), Opera Instituti Archaeologici Sloveniae 29, Inštitut za arheologijo ZRC SAZU, Založba ZRC, Ljubljana, 153-170.

Turk, M., Turk, I. 2014, Tehnologija, uporabljena pri izdelavi artefaktov / Technology used in making artefacts, in: Divje babe l: Paleolitsko najdišče mlajšega pleistocena v Sloveniji, II. del: Arheologija / Divje babe l: Upper Pleistocene Palaeolithic site in Slovenia, Part Il: Archaeology, Turk I. (ed.), Opera Instituti Archaeologici Sloveniae 29, Inštitut za arheologijo ZRC SAZU, Založba ZRC, Ljubljana, 57-78.

Vogel, J. C., Waterbolk, H. T. 1972, Groningen radiocarbon dates X, Radiocarbon, Vol. 14(1), 6-110.

Vukosavljević, N., Ahern, J. C. M., Raguž, K. 2015, Izvještaj o zaštitnim arheološkim istraživanjima u pećini Veternici 2015. godine, neobjavljeni izvještaj.

Vukosavljević, N., Raguž, K. 2016, Izvještaj o zaštitnim arheološkim istraživanjima u pećini Veternici 2016. godine, neobjavljeni izvještaj.

Zupanič, J. 1970, Petrografska istraživanja paleolitskih artefakata krapinskog nalazišta, in: Krapina 1899-1969, Malez M. (ed.), Mladost, Zagreb, 131-140. 


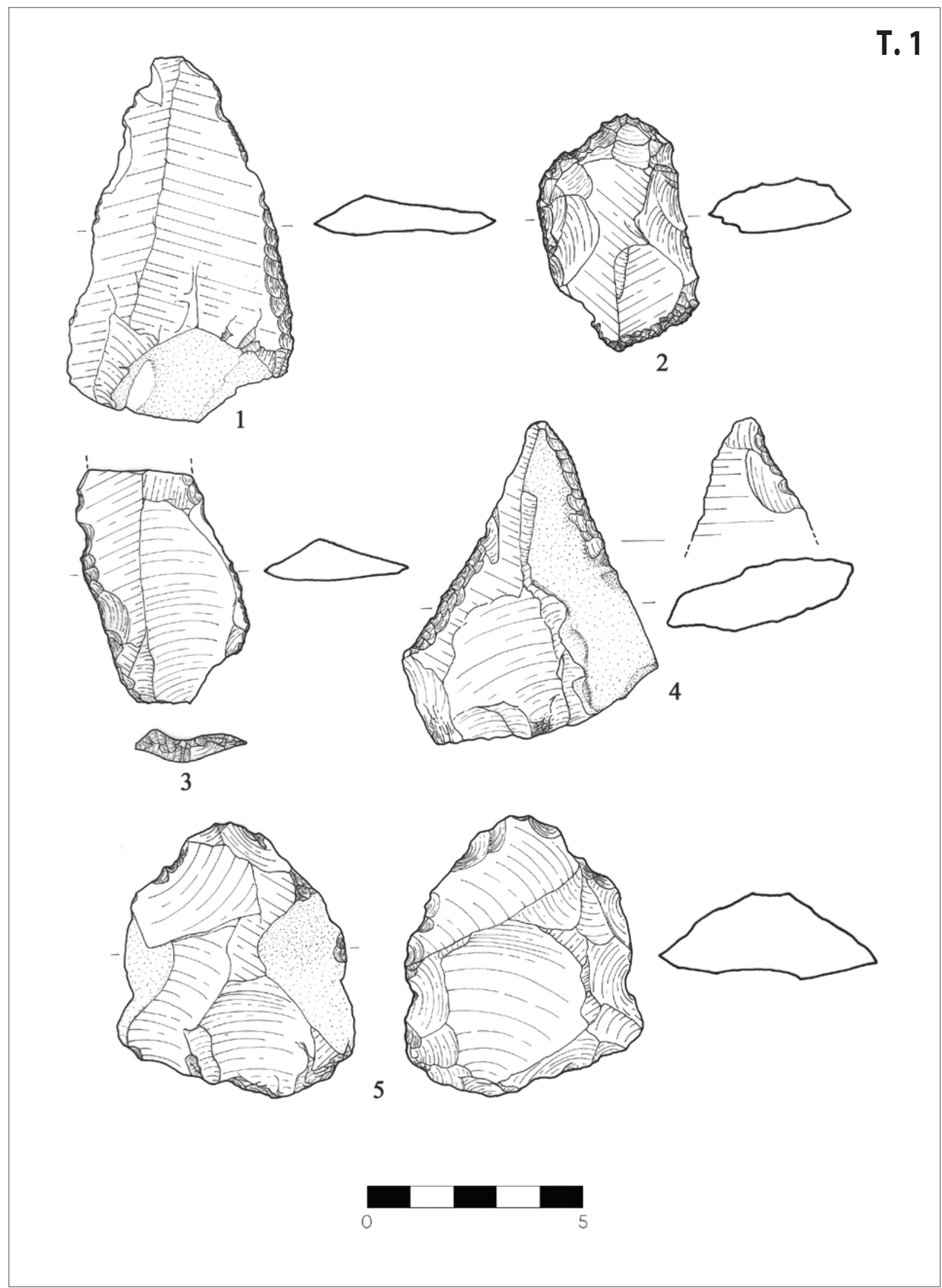

T. 1 Kamene izrađevina iz sloja J. 1: jednostrano ravno strugalo; 2: jednostrano izbočeno strugalo; 3: jednostrano ravno strugalo; 4: mustjerski šiljak; 5: centripetalna jezgra (M u cm; nacrtao: D. Branković; doradio: J. Barbarić, 2019.)

PI. 1 Stone artefacts from layer J. 1: straight sidescraper; 2: convex sidescraper; 3: straight sidescraper; 4: Mousterian point; 5: centripetal cores (scale in cm; drawning by: D. Branković; modified by: J. Barbarić, 2019) 


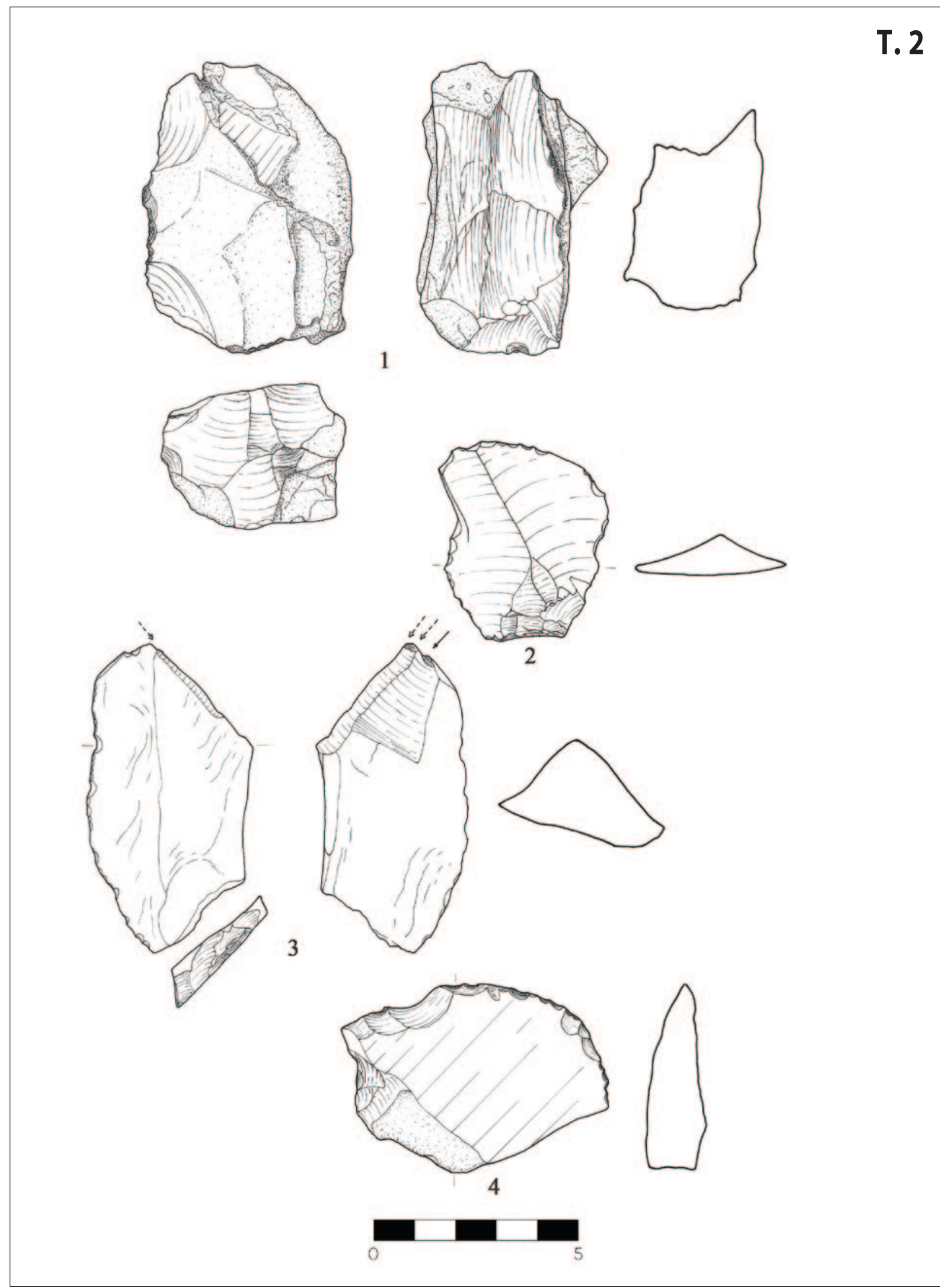

T. 2 Kamene izrađevine iz sloja J. 1: nepravilna jezgra s višesmjernim lomljenjem; 2: pseudooruđe; 3: dubilo; 4: svrdlo (M u cm; nacrtao: D. Branković; doradio: J. Barbarić, 2019.)

PI. 2 Stone artefacts from layer J. 1: irregular core with multidirectional reduction; 2: pseudo-tool; 3: burin; 4: borer (scale in cm; drawning by: D. Branković; modified by: J. Barbarić, 2019) 

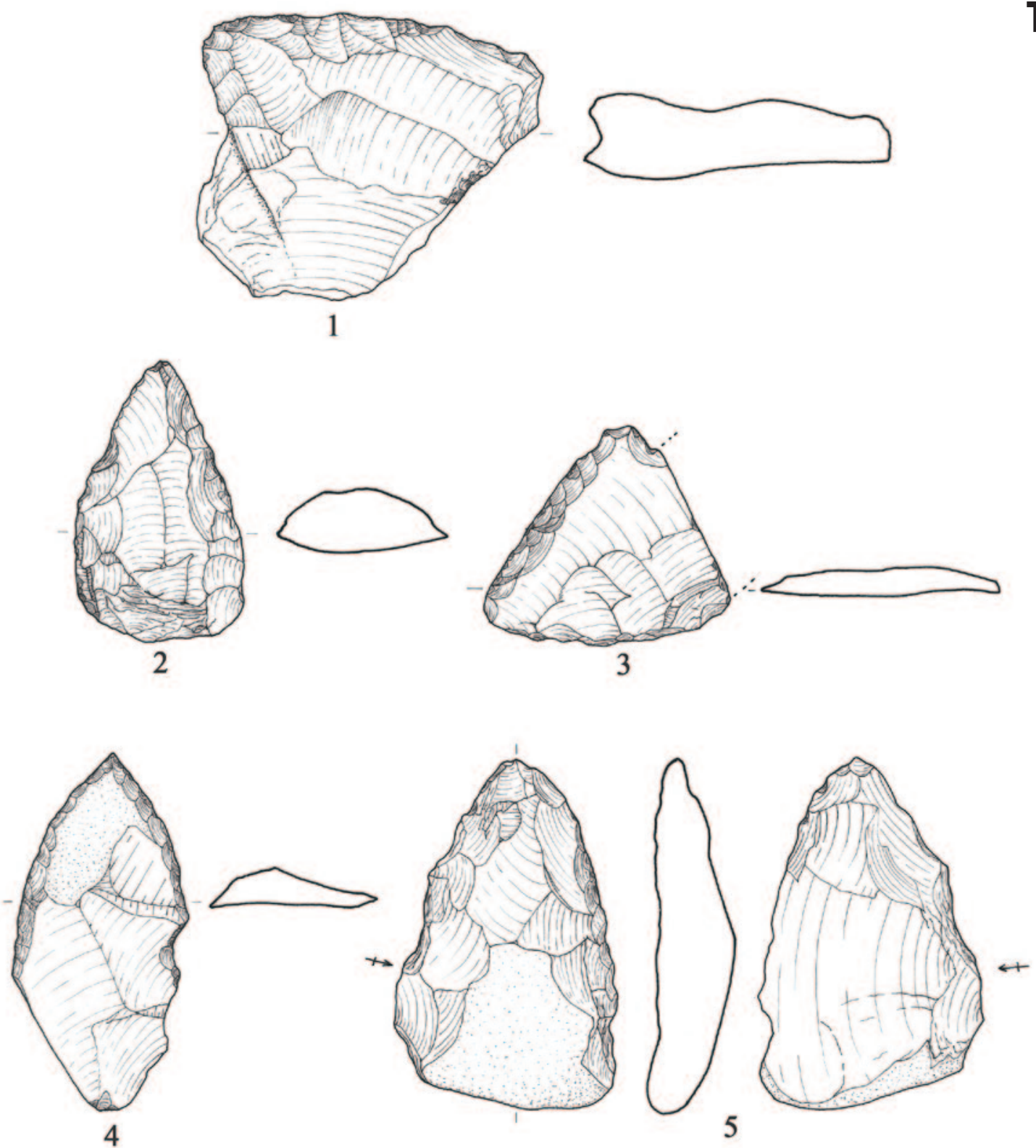

5

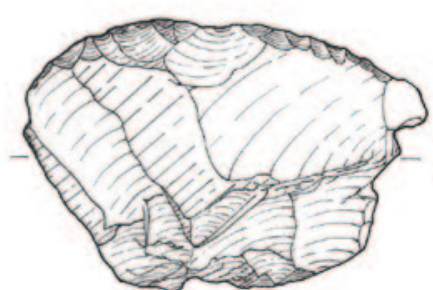

6
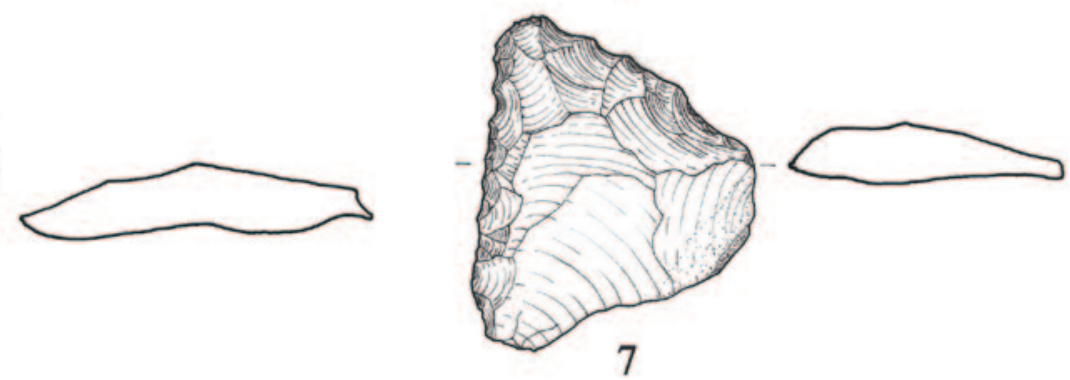

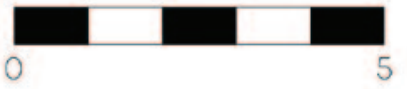

T. 3 Kamene izrađevine iz sloja I. 1: poprečno izbočeno strugalo; 2: mustjerski šiljak; 3: jednostrano izbočeno strugalo; 4 mustjerski šiljak; 5: primično strugalo; 6: poprečno izbočeno strugalo; 7: kutno strugalo (M u cm; nacrtao: D. Branković; doradio: J. Barbarić, 2019.)

PI. 3 Stone artefacts from layer I. 1: transverse convex scraper; 2: Mousterian point; 3: convex sidescraper; 4: Mousterian point; 5: convergent scraper; 6: transverse convex scraper; 7: déjeté scraper (scale in cm; drawing by: D. Branković; modified by: J. Barbarić, 2019) 


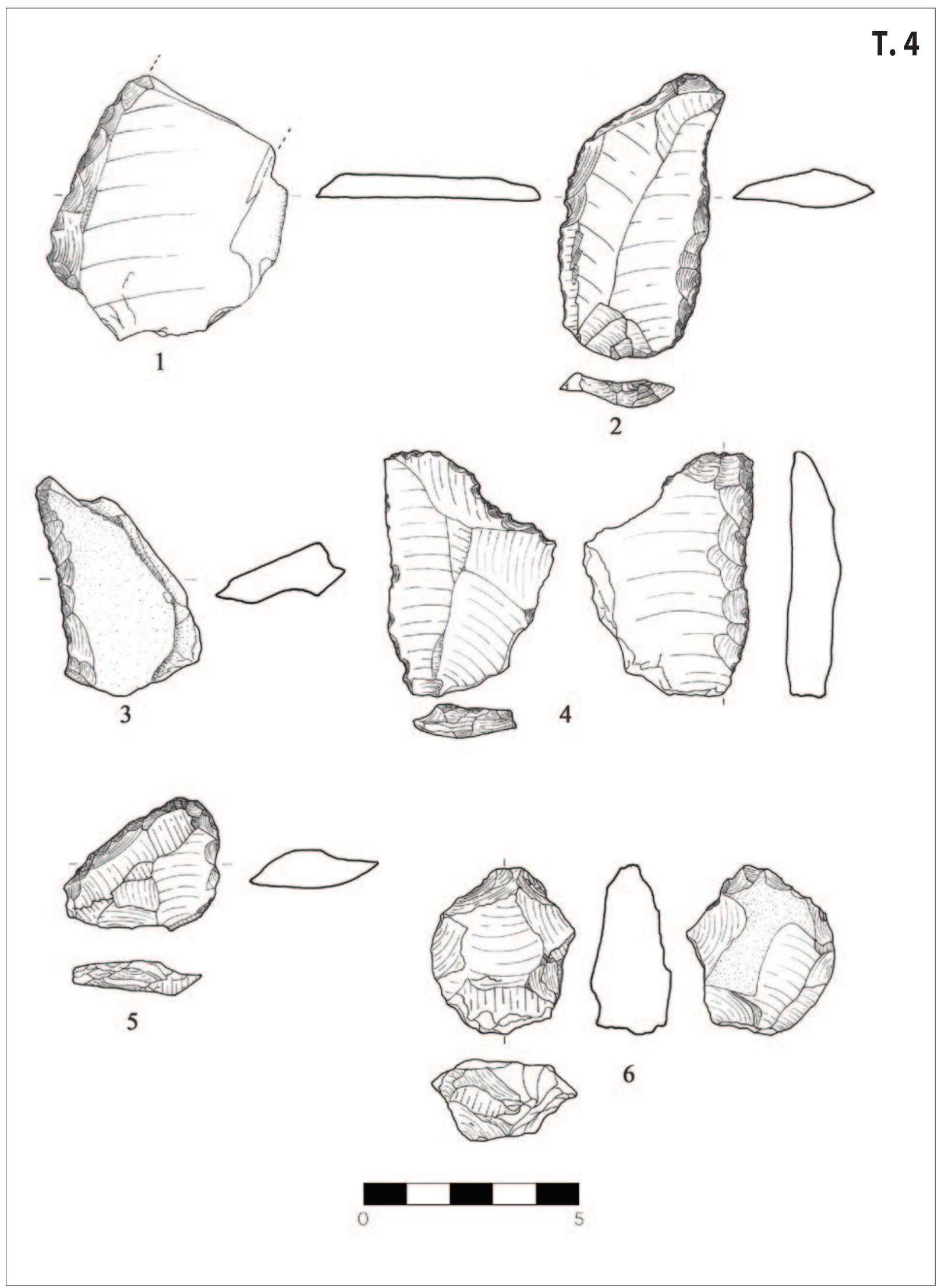

T. 4 Kamene izrađevine iz sloja H. 1: jednostrano izbočeno strugalo; 2: jednostrano izbočeno strugalo; 3: jednostrano udubljeno strugalo; 4: strugalo na ravnoj strani; 5: kutno strugalo; 6: centripetalna jezgra ( $\mathrm{M} \mathrm{u} \mathrm{cm}$; nacrtao: D. Branković; doradio: J. Barbarić, 2019.)

PI. 4 Stone artefacts from layer H. 1: convex sidescraper; 2: convex sidescraper; 3: concave sidescraper; 4: scraper on interior surface; 5: déjeté scraper; 6. centripetal core (scale in cm; drawing by: D. Branković; modified by: J. Barbarić, 2019) 


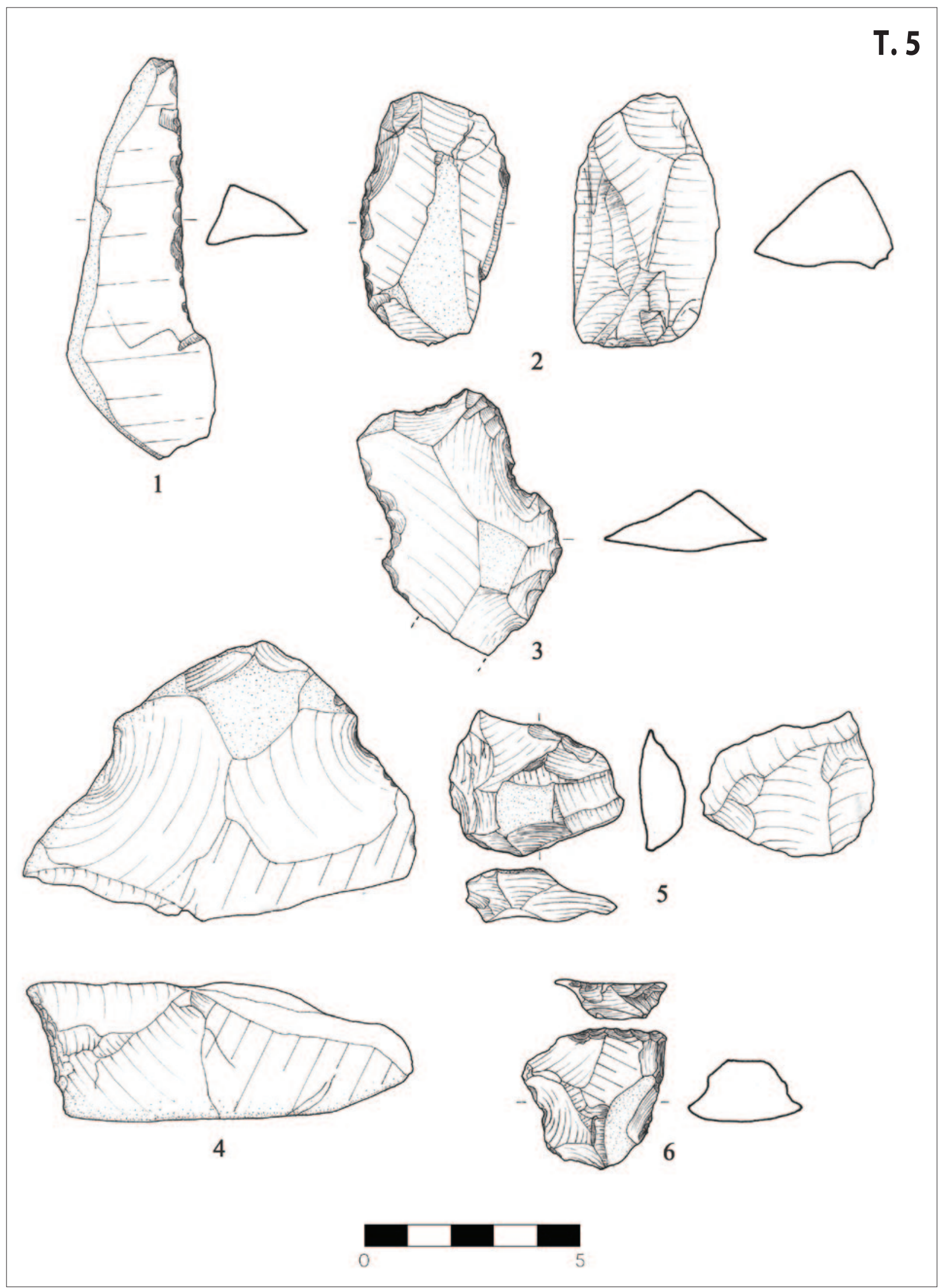

T. 5 Nalazi bez stratigrafskih podataka, osim T. 5: 2 (sloj I). 1: jednostrano ravno strugalo; 2: jednostrano izbočeno strugalo (nepravilna višesmjerna jezgra); 3: udubak; 4: centripetalna jezgra; 5: centripetalna jezgra; 6: kutno strugalo (M u cm; nacrtao: D. Branković; doradio: J. Barbarić, 2019.)

PI. 5 Finds without stratigraphic information, with the exception of PI. 5: 2 (layer I). 1: straight sidescraper; 2: convex scraper (irregular multidirectional core); 3: notch; 4: centripetal core; 5: centripetal core; 6: déjeté scraper (scale in cm; drawing by: D. Branković; modified by: J. Barbarić, 2019) 


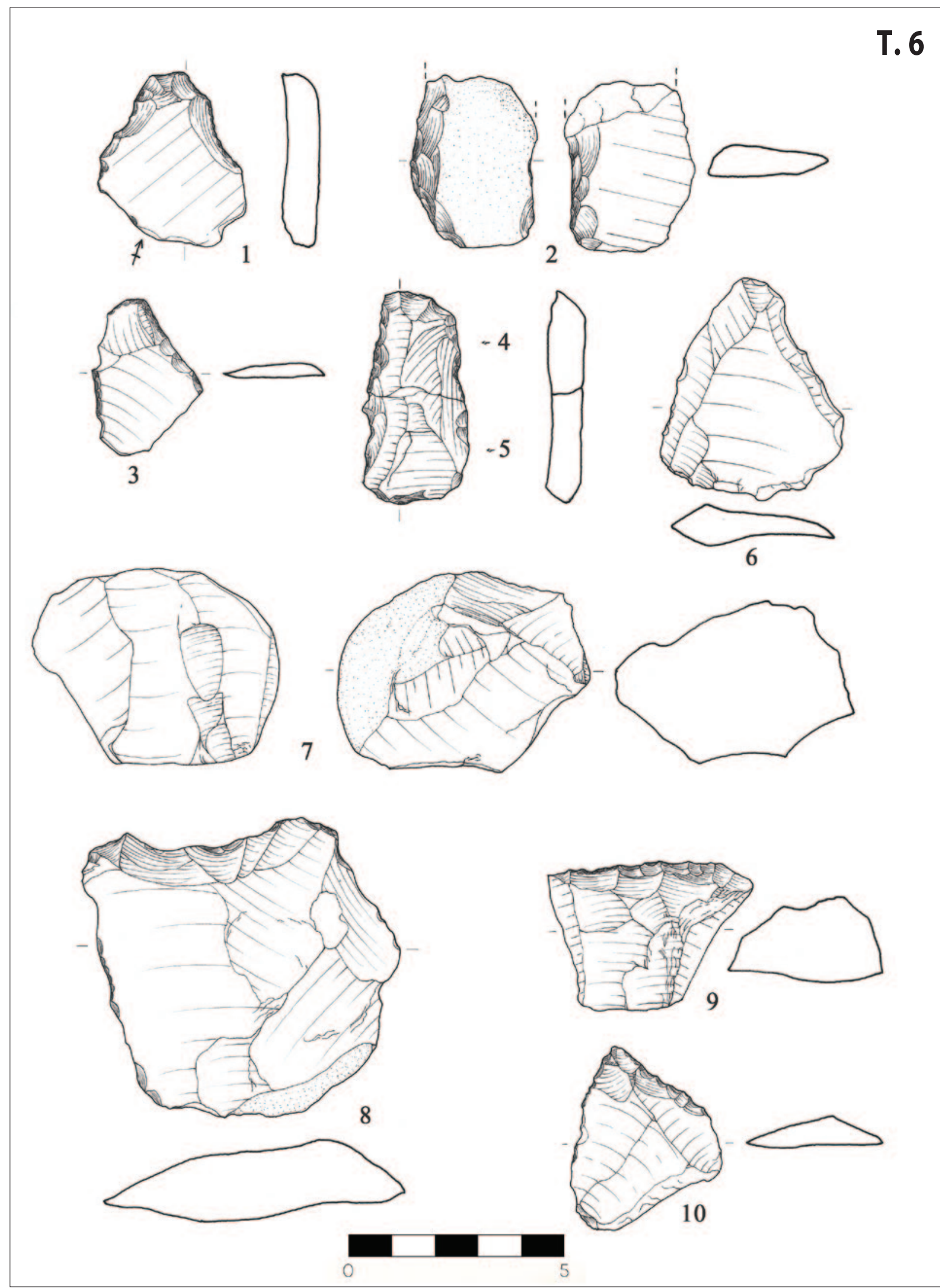

T. 6 Nalazi bez stratigrafskih podataka. 1: grebalo; 2: izmjenično strugalo; 3: strugalica; 4-5: grebalo; 6: nož s hrptom; 7: jezgra s nasuprotnim lomljenjem; 8: poprečno udubljeno strugalo; 9: poprečno izbočeno strugalo; 10: primično strugalo (M u cm; nacrtao: D. Branković; doradio: J. Barbarić, 2019.)

PI. 6 Finds without stratigraphic information. 1: endscraper; 2: alternate scraper; 3: raclette; 4-5: endscraper; 6: backed knife; 7: core with opposite reduction; 8: transverse concave scraper; 9: transverse concave scraper; 10: convergent scraper (scale in cm; drawing by: D. Branković; modified by: J. Barbarić, 2019) 


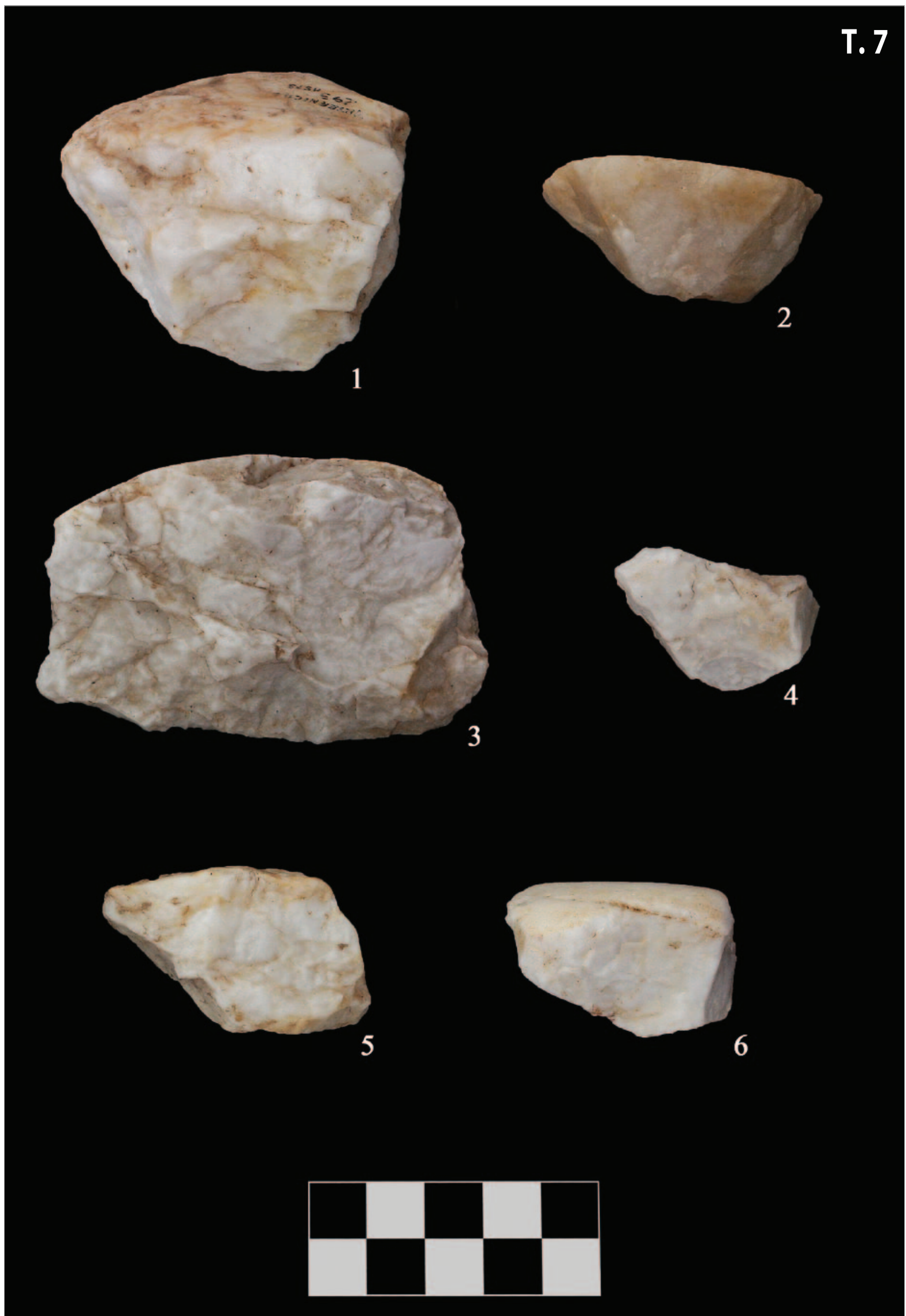

T. 7 Kvarcne jezgre bez stratigrafskih podataka. 1-3 i 5-6: klinasta jezgra; 4: bipolarna jezgra (M u cm; snimio: M. Petrović; doradili: J. Barbarić i M. Banda, 2019.)

PI. 7 Quartz cores without stratigraphic information. 1-3 and 5-6: cobble-wedge core; 4: bipolar core (scale in cm; photo: M. Petrović; modified by: J. Barbarić and M. Banda, 2019) 